\title{
ESTUDO DA EXPRESSÃO DA PROTEÍNA AIRE (AUTOIMMUNE REGULATOR) E DOS COMPONENTES DA VIA DE SINALIZAÇÃO NOTCH EM TIMOS HUMANOS
}

Tese apresentada ao programa de Pós-Graduação em Parasitologia do Instituto de Ciências Biomédicas da Universidade de São Paulo, para obtenção de título de Doutor em Ciências.

São Paulo

2010 


\section{ESTUDO DA EXPRESSÃO DA PROTEÍNA AIRE (AUTOIMMUNE REGULATOR) E DOS COMPONENTES DA VIA DE SINALIZAÇÃO NOTCH EM TIMOS HUMANOS}

Tese apresentada ao programa de Pós-Graduação em Parasitologia do Instituto de Ciências Biomédicas da Universidade de São Paulo, para obtenção de título de Doutor em Ciências.

Área de concentração: Biologia da Relação Patógeno-Hospedeiro

Orientadora: Prof ${ }^{a}$. Dra $\stackrel{a}{ }$. Magda Maria Sales Carneiro-Sampaio

São Paulo

2010 
DADOS DE CATALOGAÇÃO NA PUBLICAÇÃO (CIP)

Serviço de Biblioteca e Informação Biomédica do

Instituto de Ciências Biomédicas da Universidade de São Paulo

(c) reprodução total

Lima, Flávia Afonso.

Estudo da expressão da proteína AIRE (autoimmune regulator) e dos componentes da via de sinalização Notch em timos humanos. I Flávia Afonso Lima. -- São Paulo, 2010.

Orientador: Magda Maria Sales Carneiro Sampaio.

Tese (Doutorado) - Universidade de São Paulo. Instituto de Ciências Biomédicas. Departamento de Parasitologia. Área de concentração: Biologia da Relação Patógeno-Hospedeiro. Linha de pesquisa:

Desenvolvimento da resposta imune; imunodeficiências.

Versão do título para o inglês: Expression of AIRE (autoimmune regulator) and Notch components in human thymus.

Descritores: 1. Timo humano 2. Receptores Notch 3 . Ligantes Notch 4. Aire 5.Síndrome de Down 6. Autoimunidade I. CarneiroSampaio, Magda Maria Sales II. Universidade de São Paulo. Instituto de Ciências Biomédicas. Programa de Pós-Graduação em Biologia da Relação Patógeno-Hospedeiro III. Título. 


\section{UNIVERSIDADE DE SÃO PAULO INSTITUTO DE CIÊNCIAS BIOMÉDICAS}

Candidato(a):

Flávia Afonso Lima.

Título da Tese:

Estudo da expressão da proteína AIRE (autoimmune regulator) e dos componentes da via de sinalização Notch em timos humanos.

Orientador(a):

Magda Maria Sales Carneiro Sampaio.

A Comissão Julgadora dos trabalhos de Defesa da Tese de Doutorado, em sessão pública realizada a considerou

\section{( ) Aprovado(a) \\ ( ) Reprovado(a)}

Examinador(a): Assinatura:

Nome:

Instituição:

Examinador(a): Assinatura:

Nome:

Instituição:

Examinador(a): Assinatura:

Nome:

Instituição:

Examinador(a): Assinatura:

Nome:

Instituição:

Presidente: Assinatura:

Nome:

Instituição: 
São Paulo, 19 de agosto de 2009.

\section{PARECER 913/CEP}

Prezada Senhora,

Atendendo sua solicitação, a Comissão de Ética em Pesquisas com Seres Humanos do $I C B$, em sua $97^{a}$ reunião realizada em 18.08 .09 , analisou 0 projeto de sua responsabilidade intitulado: "Estudo da distribuição de ligantes $e$ receptores notch nas diferentes populações celulares do timo humano".

Informo a V.Sa. que, após análise e discussão, o referido projeto foi aprovado por esta Comissão.

Lembramos que cabe ao pesquisador elaborar e apresentar a este Comitê, relatórios anuais (parciais ou final), de acordo com a resolução 196/06 do Conselho Nacional da Saúde, item IX.2 letra c.

O primeiro relatório deverá ser encaminhado à Secretaria deste CEP em 18 de agosto de 2010.

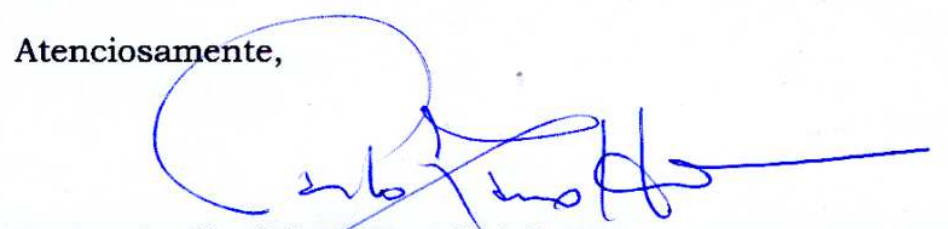

Prof. Dr. PAOLO M.A ZANOTTO

Vice-Coordenador da Comissão de Ética em Pesquisas com Seres Humanos - ICB/USP

Ilma. Sra.

FLÁVIA AFONSO LIMA

Departamento de Parasitologia

Instituto de Ciências Biomédicas -USP

Comissão de Ética em Pesquisa com Seres Humanos do Instituto de Ciências Biomédicas / USP Aprovada pela Comissão Nacional de Ética em Pesquisa - CONEP, em 10 de fevereiro de 1998. 


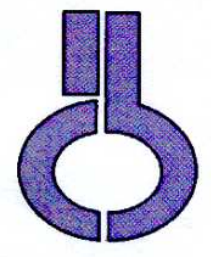

UNIVERSIDADE DE SÃO PAULO

INSTITUTO DE CIÊNCIAS BIOMÉDICAS

Cidade Universitária "Armando de Salles Oliveira"

Av. Prof. Lineu Prestes, 2415 - cep. 05508-000 Săo Paulo, SP - Brasılı

Telefone: (55) (011) 30917733 - telefax: (55) (011) 30918405

Decl. CEPSH. 038.2010

DE CLARAÇÃ O

Em adendo ao parecer 913/CEP, de 18.08.09, informo que o titulo do Projeto foi alterado para "ESTUDO DA EXPRESSÃO DA PROTEÍNA AIRE (AUTOIMUNE REGULATOR) E DOS COMPONENTES DA VIA DE SINALIZAÇÃO NOTCH EM IIMOS HUMANOS" não apresentando restriçōes quanto às modificaçōes do projeto, que as mesmas não afetam os aspectos éticos da pesquisa.

São Paulo, 05 de maio de 2010.

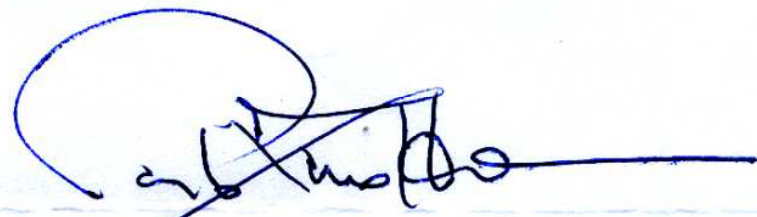

Prof. Di. PaOlo M.A. ZanotTo

Coordenador da Comissão de Ética em

Pesquisas com Seres Humanos - ICB /USP 


\section{WCor}

Associaçåo do
Sanatório Sírio

CEP/HCor - 003/2006-Apr

\section{APROVAÇÃO}

A Comitê de Ética em Pesquisa - CEP/HCor, sessão de 15.02.2006, APROVOU $O$ protocolo de pesquisa intitulado "ESTUDO DA DISTRIBUIÇÃO DE LIGANTES E RECEPTORES NOTCH NAS DIFERENTES POPULAÇÕES CELULARES DO TIMO HUMANO", SOb responsabilidade de execução dos autores Prof.Dr.Alberto Duarte, Profa. Dra.Magda Maria Salles Carneiro-Sampaio e a Biomédica Flávia Afonso Lima.

Cabe aos pesquisadores executantes elaborar e apresentar ao Comitê de Ética em Pesquisa do Hospital do Coração - CEP/HCor, os relatórios parciais e final sobre a pesquisa, (Resolução do Conselho Nacional de Saúde n 196, de 10.10.1996, inciso IX. 2, letra "c").

CEP/HCor, 15 de Fevereiro de 2006

Prof. Dr. Carlò Ás Álberto Búchpiguel

Coordenador do Comitê de Ética ém Pesquisa do HCor 
Este trabalho foi realizado pelo Programa de Pós-Graduação do Departamento de Parasitologia do Instituto de Ciência Biomédicas da Universidade de São Paulo, com auxílio financeiro da Fundação de Amparo à Pesquisa do Estado de São Paulo (FAPESP), Bolsa de Doutorado, Processo ㄲo 05/60069-8. 
Àqueles que amo. 


\section{AGRADECIMENTOS}

À Prof ${ }^{\mathrm{a}}$. Dra . Magda Carneiro-Sampaio, por ter me aceitado em seu grupo, pela orientação, apoio e incentivo durante todos esses anos de convivência.

À Prof ${ }^{a}$. Dr ${ }^{a}$. Irma Seixas Duarte, que carinhosamente me abriu as portas de seu laboratório, onde a maior parte dos ensaios de imunohistoquímica foi realizada.

Ao Prof. Dr. António Coutinho, diretor do Instituto Gulbenkian de Ciência (Oeiras/Portugal), por ter me recebido em seu laboratório, por todo apoio e colaboração.

À Prof ${ }^{\mathrm{a}}$. Dra ${ }^{\mathrm{a}}$. Leonor Parreira e ao Prof. Dr. António Cidadão, do Instituto de Medicina Molecular (Lisboa/Portugal) pela colaboração.

Ao Prof. Dr. Alberto Duarte pelo incentivo e colaboração.

Aos caros cirurgiões Dra. Magaly Arraes e Dr. Luiz Bento pela valiosa colaboração com a coleta das amostras de timo.

Às crianças, aos seus pais e responsáveis pela doação dos timos para pesquisa científica.

À Luciana Bento pela colaboração, companheirismo e apoio.

Aos professores Dr. Niels Câmara, Dr. Marcelo Barcinski, Dr. Dilton Vasconcelos e Drạ- Bernadete Liphaus pelas valiosas sugestões durante o meu exame de qualificação.

Aos caros Dr. Calos Alberto Moreira, Dr ${ }^{\mathrm{a}}$. Beatriz Alves e Dra . Patrícia Locosque pela colaboração. 
Aos amigos que conheci além-mar Claudio, Lisa, Natacha, Dr ${ }^{\mathrm{a}}$ Natália Ferreira, Rosa pelo apoio e companheirismo.

Às amigas do LIM36 Ana Lúcia, Camila, Gerlândia, Leuridan e Patrícia Palmeira, por tudo que me ensinaram, pelo incentivo, paciência e harmonioso convívio.

Aos amigos do Laboratório de Moléstias Transmissíveis Carla, Cleusa, Dantas, Elaine, Felipe, Mônica, Naiura e Rosana, pelo acolhimento, incentivo, sugestões e ajuda.

Às amigas Márcia, Rosana, Elaine e Simone pelo apoio.

À secretária dos professores do Departamento de Pediatria do Instituto da Criança (FM-USP), Ana Carolina Vieira, pela preciosa ajuda em diversos momentos.

Às secretárias da Pós-Graduação Vilma e Ângela, pelas valiosas informações e orientações.

Aos meus queridos pais, Leão e Maria da Assunção, meus irmãos, Henrique e Fabíola, e meu lief Sander, que sempre me perdoaram pelos longos períodos de ausência, pela compreensão, paciência e constante incentivo.

À Fundação de Amparo à Pesquisa do Estado de São Paulo (FAPESP) pelo apoio financeiro.

A todas as pessoas que direta ou indiretamente colaboraram para a realização desse trabalho. 
"Não há o que se faça no laboratório que a natureza não tenha feito!" Osvaldo Sant'Anna 


\section{RESUMO}

Lima FA. Estudo da expressão da proteína AIRE (autoimmune regulator) e dos componentes da via de sinalização Notch em timos humanos. [tese (Doutorado em Parasitologia)]. São Paulo (Brasil): Instituto de Ciências Biomédicas da Universidade de São Paulo; 2010.

O timo é o órgão linfóide primário responsável pelo estabelecimento inicial de um repertório funcional de células $T$. A via de sinalização Notch é essencial para o desenvolvimento de células $T$ a partir de células-tronco hematopoiéticas, e a distribuição de seus receptores e ligantes no timo humano ainda é desconhecida. A expressão de AIRE é crucial para a seleção de um repertório de receptores de linfócitos T (TCR) sem autorreatividade. Neste estudo, analisamos o padrão de expressão de AIRE e a distribuição de Notch em timos pacientes com cardiopatias congênitas, parte dos quais com síndrome de Down. Descrevemos a localização intratímica e os tipos celulares capazes de expressar os diferentes receptores e ligantes Notch. A expressão de AIRE em células epiteliais medulares foi significantemente reduzida em timos de crianças com síndrome de Down, deficiência esta que pode explicar a alta incidência de doenças autoimunes nesta cromossomopatia.

Palavras-chave: Timo humano. Receptores Notch. Ligantes Notch. AIRE. Síndrome de Down. Autoimunidade. 


\begin{abstract}
Lima FA. Expression of AIRE (autoimmune regulator) and Notch components in human thymus. [Ph. D. thesis (Parasitology)]. São Paulo (Brazil): Instituto de Ciências Biomédicas da Universidade de São Paulo; 2010.

The thymus is a primary lymphoid organ which is essential for the initial establishment of a functional repertoire of T cells. Notch signaling is crucial for T-cell lineage development from hematopoietic stem cells; however, distribution of Notch ligands and receptors in human thymus is still unknown. AIRE is crucial for the selection of a T-cell-receptor (TCR) repertoire purged of self-reactive specificities. In this study, we analyzed the expression patterns of AIRE and Notch in human thymuses from children with congenital cardiopathies that undergo heart surgery, part of whom with Down syndrome. We described the intra-thymic localization and the cell types that express Notch receptors and ligands. AIRE expression in medullary epithelial cells is significantly decreased in Down syndrome patients. This deficiency could explain higher incidence of autoimmune disease in Down syndrome.
\end{abstract}

Keywords: Human thymus. Notch receptors. Notch ligands. AIRE. Down syndrome. Autoimmunity. 


\section{LISTA DE ABREVIATURAS, SIGLAS E SÍMBOLOS}

$\mu \mathrm{g}$

microgramas

$\mu \mathrm{m}$

micrômetros

${ }^{\circ} \mathrm{C}$

graus Celsius

AA

aneurisma de aorta

a.C.

antes de Cristo

AIRE

regulador de autoimunidade (autoimmune regulator)

ANK

ankyrin

APECED poliendocrinopatia autoimune associada à candidíase e distrofia ectodérmica

AVP atresia de valva pulmonar

BSA albumina de soro bovino

CARD caspase recruitment domain

CAV comunicação atrioventricular

CET células epiteliais do timo

CIA comunicação interatrial

CIV comunicação interventricular

$\mathrm{cm} \quad$ centímetro

$\mathrm{CR}$ região rica em serina

CSL CBF1/RBP-Jא, Suppressor of Hairless e Lag-1

CT cor triatriatrum

CTH células-tronco hematopoiéticas

CV coeficiente de variação

CVAD comunicação ventrículo-átrio discordante

D dextrocardia

DAB 3,3' diaminobenzidina

DAPI 4',6 diamidino-2-phenylindole

DII1 ligante notch delta-like 1

DII3 ligante notch delta-like 3

DII4 ligante notch delta-like 4

DN duplo-negativo 


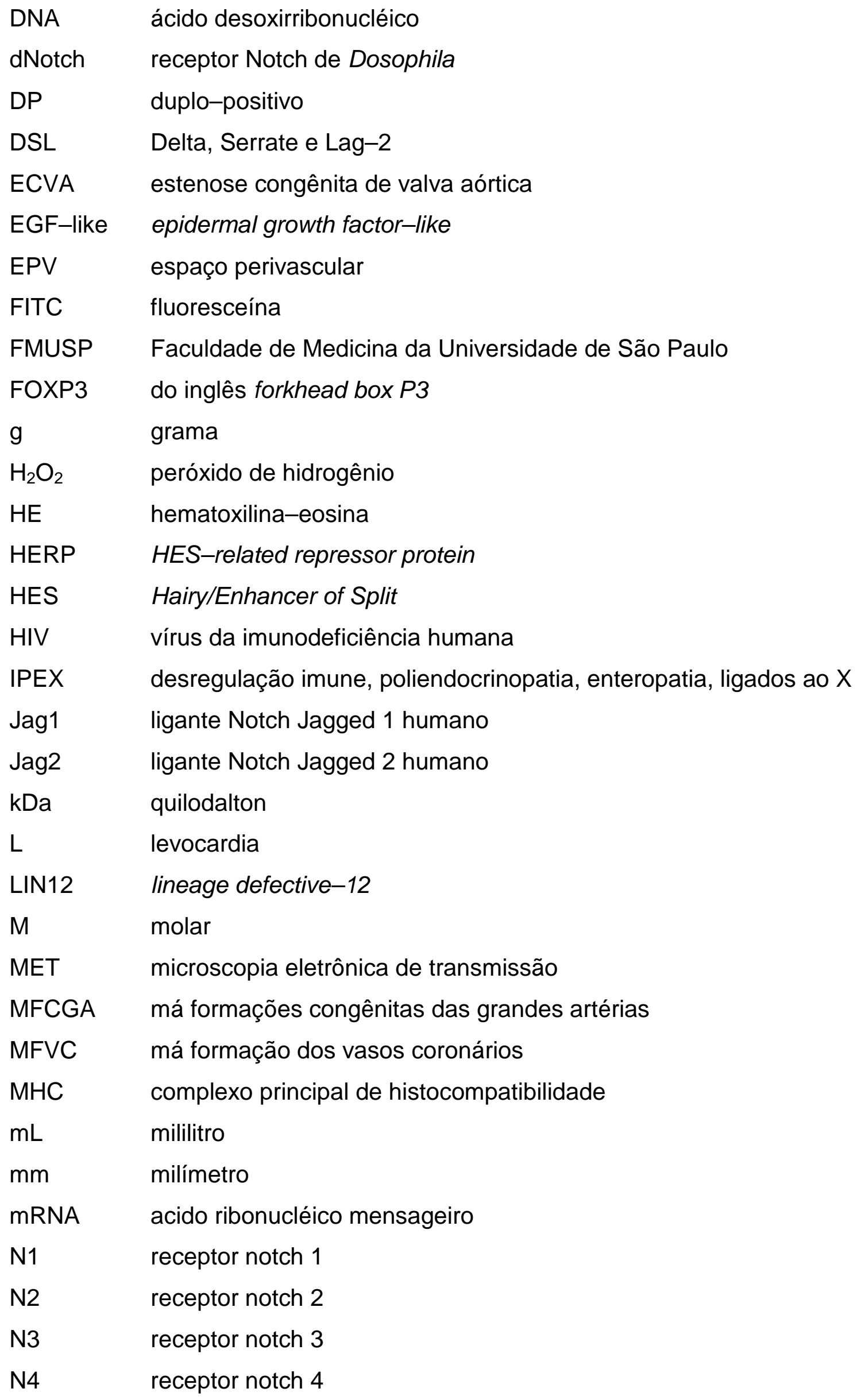


NICD domínio intracelular do receptor Notch

NK células Natural Killer

nm nanômetros

NLS nuclear localization signal

PBS tampão fosfato-salino

PEST domínio rico em prolina, glutamina, serina e treonina

$\mathrm{pH} \quad$ potencial hidrogeniônico

PHD plant homeodomain type zinc-finger

pré-TCR cadeia de TCR $\beta$ ligada covalentemente a uma cadeia de pré-TCR $\alpha$ invariante e CD3

PRR proline-rich region

RAG1 gene ativador de recombinase 1

RAG2 gene ativador de recombinase 2

RAM $\quad R B P-J K$-associated module

SAND Sp100, AIRE, NucP41/75, DEAF-1

SCEH síndrome do coração esquerdo hipoplásico

SD síndrome de Down

SDG síndrome DiGeorge

SP simples-positive

$\mathrm{T} \alpha \beta \quad$ linfóticos $\mathrm{T}$ da linhagem $\alpha \beta$

$\mathrm{T} \gamma \delta \quad$ linfóticos $\mathrm{T}$ da linhagem $\gamma \delta$

TAD domínio de transativação

TCR receptor de células T

TF tetralogia de Fallot/Comunicação aortopulmonar

Th1 linfóticos T auxiliares 1

Th2 linfóticos $T$ auxiliares 2

TNF- $\alpha \quad$ tumour necrosis factor

TREC círculo de excisão do TCR

Treg linfócitos $\mathrm{T}$ regulatórios

TSLP linfopoietina estromal tímica

VDDS ventrículo direito com dupla via de saída 


\section{LISTA DE FIGURAS}

Figura 1. Corte histológico de timo humano corado pelo método Hematoxilina-Eosina..

Figura 2. Mudanças no volume relativo (\%) dos compartimentos tímicos em relação à idade do indivíduo.

Figura 3. Representação esquemática da estrutura da proteína AIRE humana.

Figura 4. Imunomarcação de diferentes tipos celulares intratímicos....

Figura 5. Imunofluorescência de AIRE na região medular do timo.

Figura 6. Ensaio de dupla marcação com os anticorpos primários anti-AIRE e antipan-citoqueratina.

Figura 7. Imunohistoquímica para detecção de AIRE no timo humano.

Figura 8. Imunohistoquímica para detecção de Foxp3 em timo humano.

Figura 9. Média e desvio padrão do $n^{\circ}$ de células expressando (A) AIRE $(159,1 \pm 60,96$; CV=38\%) e (B) Foxp3 $(719,1 \pm 229,60 ; C V=32 \%)$ em 46 timos humanos.

Figura 10. Análises através do teste estatístico de Mann-Whitney mostrando não haver diferenças significantes $(p=n s)$ entre $(\mathbf{A})$ a expressão de AIRE e (B) de Foxp3 e a faixa etária dos pacientes menores $(n=30)$ e maiores $(n=16)$ de um ano de vida.

Figura 11. Teste de Mann-Whitney mostrando não haver diferenças significantes entre (A) a expressão de AIRE ou (B) de Foxp3 e o sexo dos pacientes (feminino $n=24$ e masculino $n=22$ ).

Figura 12. Correlação de Pearson mostrando não haver correlação significante entre a idade dos pacientes e a expressão de (A) AIRE $(r=0.04, p=n s)$ e de (B) Foxp3 $(r=0.10 ; p=n s)$.

Figura 13. Análise estatística mostrando não haver correlação significante ( $r=0.15 ; p=n s)$ entre $0 n^{\circ}$ de células epiteliais IIRE $^{+}$e o $n^{\circ}$ de timócitos Foxp3 ${ }^{+}$.

Figura 14. Corte histológico de lóbulo tímico do grupo SD.

Figura 15. Imunomarcação de diferentes tipos celulares em timo do grupo SD.

Figura 16. Imunohistoquímica para detecção de AIRE em timos de pacientes dos grupos (A) SD e (B) controle.

Figura 17. Imunohistoquímica para detecção de Foxp3 em timo de paciente do grupo SD.

Figura 18. Média e desvio padrão do $n^{\circ}$ de células expressando (A) AIRE $(77,9 \pm 55,94$; $\mathrm{CV}=72 \%)$ e (B) Foxp3 (820,9 $\pm 477,60 ; \mathrm{CV}=58 \%)$ em 15 timos provenientes de crianças com síndrome de Down. 
Figura 19. Análises através do teste estatístico de Mann-Whitney mostrando (A) uma diferença significante $(p=0.01)$ de expressão de AIRE entre os pacientes menores $(n=6)$ e maiores $(n=9)$ de um ano de vida, enquanto $(B)$ não houve diferença significante de expressão de Foxp3 entre as faixas etárias.

Figura 20. Teste de Mann-Whitney mostrando não haver diferenças significantes entre (A) a expressão de AIRE ou (B) de Foxp3 e o sexo dos pacientes (feminino $n=9$ e masculino $n=6)$

Figura 21. Correlação de Pearson mostrando não haver correlação significante entre a idade dos pacientes e a expressão de (A) AIRE e de (B) Foxp3.

Figura 22. Análise estatística pelo teste de Mann-Whitney. Em (A) observa-se uma diferença significante $(p<0.0001)$ de expressão de AIRE entre os grupos SD e controle, e em (B) não foram encontradas diferenças significantes entre os grupos em relação à expressão de Foxp3.

Figura 23. Correlação de Pearson mostrando o aumento significante de Foxp3 concomitante com o aumento do número de células AIRE $^{+}$nos timos do grupo SD ( $r=0.75 ; p=0.001)$; no grupo controle há um leve aumento não significante $(r=0.15 ; p=n s)$.

Figura 24. Esquema estrutural dos ligantes e receptores Notch.

Figura 25. Representação esquemática da sinalização mediada por Notch.

Figura 26. Imunofluorescência (FITC) de fluorescência para detecção de N1

Figura 27. Imunohistoquímica para detecção de N1 em tecido tímico.

Figura 28. Imunofluorescência (FITC) de corte tímico tratado com anti-Notch2

Figura 29. Imunofluorescência (FITC) de corte tímico incubado com anti-Notch3.

Figura 30. Imunofluorescência (FITC) de corte tímico tratado com anti-DII4.

Figura 31. Imunofluorescência (FITC) de tecido tímico incubado com anti-Jag1.

Figura 32. Imunofluorescência (FITC) de corte tímico tratado com anti-Jag2. 


\section{LISTA DE TABELAS}

Tabela 1 - Apresentação dos anticorpos primários utilizados para o estudo de AIRE e Foxp3 no timo humano.

Tabela 2 - Dados dos pacientes doadores dos timos e resultados das contagens de células $\mathrm{AIRE}^{+}$e Foxp3 ${ }^{+}$por $\mathrm{mm}^{2}$ de medula tímica.

Tabela 3 - Dados dos pacientes com síndrome de Down e resultados das contagens de células AIRE ${ }^{+}$e Foxp3 ${ }^{+}$por $\mathrm{mm}^{2}$ de medula tímica.

Tabela 4 - Identificação dos timos estudados quanto à expressão de Notch.

Tabela 5 - Anticorpos primários utilizados para estudar a distribuição de Notch no timo humano.

Tabela 6 - Resumo da distribuição de receptores e ligantes Notch no timo humano. 


\section{SUMÁRIO}

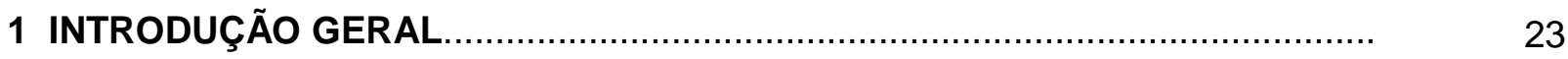

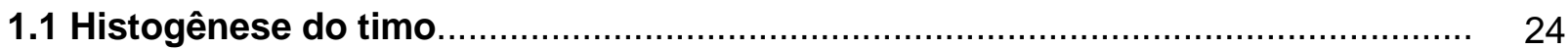

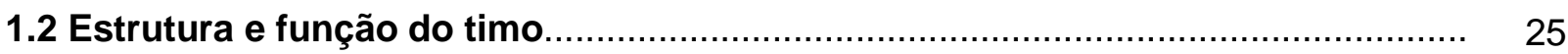

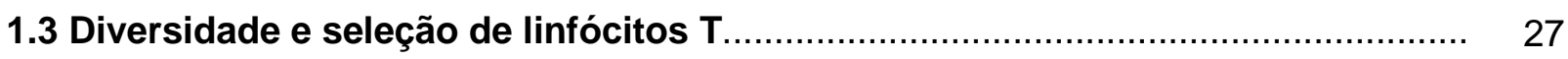

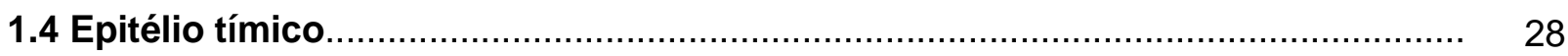

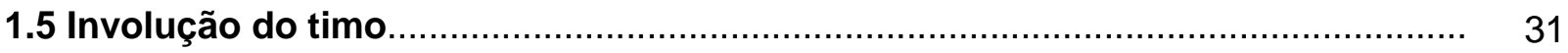

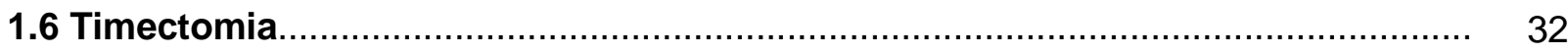

1.7 Síndrome DiGeorge e transplante de timo..................................................... 33

2 ESTUDO DA EXPRESSÃO DAS PROTEÍNAS AIRE E FOXP3 NO TIMO HUMANO.. 36

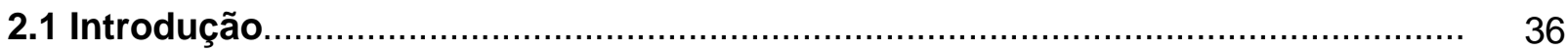

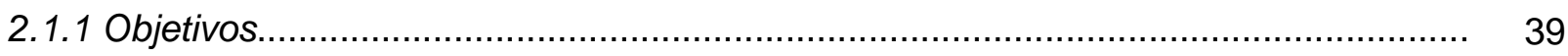

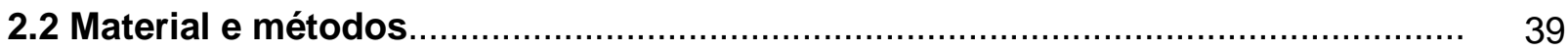

2.2.1 Coleta e armazenamento dos timos humanos...................................................... 39

2.2.2 Cortes histológicos, desparafinização e hidratação dos tecidos.............................. 40

2.2.3 Coloração de cortes tímicos pelo método de HE................................................ 40

2.2.4 Imunohistoquímica................................................................................. 41

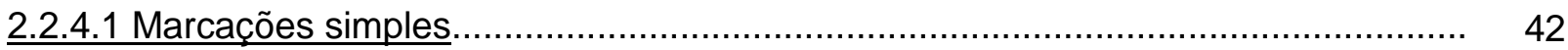

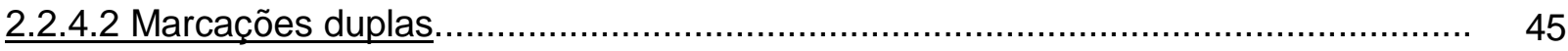

2.2.5 Contagem celular e análises estatísticas....................................................... 46

2.2.6 Espécimes de timos e anticorpos utilizados......................................................... 46

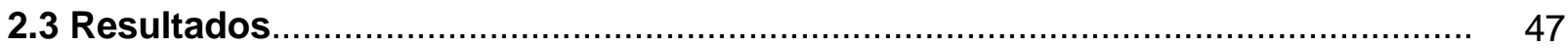

2.3.1 Coloração dos timos pelo método de HE........................................................... 47

2.3.2 Imunohistoquímica para identificação e análise da distribuição de células intratímicas.............................................................................. 47

2.3.3 Imunohistoquímica para detecção de AIRE e Foxp3 no timo humano...................... 49 
2.3.4 Contagens de células AIRE $^{+}$e Foxp $3^{+}$por $\mathrm{mm}^{2}$ de medula tímica e análises estatísticas dos dados.

2.4 Discussão

3 ESTUDO DA EXPRESSÃO DAS PROTEÍNAS AIRE E FOXP3 EM TIMOS DE CRIANÇAS PORTADORAS DA SÍNDROME DE DOWN.

3.1 Introdução.

3.1.1 Objetivos.

3.2 Material e métodos

3.3 Resultados

3.3.1 Coloração dos timos de pacientes com SD pelo método de HE.

3.3.2 Imunohistoquímica para identificação e análise da distribuição de células intratímicas do grupo $S D$.

3.3.3 Imunohistoquímica para detecção de AIRE e Foxp3 em timos do grupo SD.

3.3.4 Contagens de células AIRE $^{+}$e Foxp3 ${ }^{+}$nos timos do grupo $S D$, análises estatísticas dos dados.

3.4 Discussão

4 ESTUDO DA DISTRIBUIÇÃO DE LIGANTES E RECEPTORES NOTCH NO TIMO HUMANO.

4.1 Introdução.

4.1.1 Objetivos.

4.2 Material e métodos.

4.3 Resultados

4.4 Discussão.

5 CONCLUSÕES

ANEXO A - Modelo do termo de consentimento. 
ANEXO B.1 - Contagens de células epiteliais $\mathrm{AIRE}^{+}$, por campo, na medula tímica de 46 timos humanos...

ANEXO B.2 - Contagens de timócitos Foxp3 ${ }^{+}$, por campo, na medula tímica de 46 timos humanos.

ANEXO B.3 - Contagens de células epiteliais $\mathrm{AIRE}^{+}$, por campo, na medula tímica de 15 timos provenientes de crianças com síndrome de Down.

ANEXO B.4 - Contagens de timócitos Foxp3 ${ }^{+}$, por campo, na medula tímica de 15 timos provenientes de crianças com síndrome de Down.

ANEXO C.1 - Produção bibliográfica: Publicação.

ANEXO C.2 - Produção bibliográfica: Manuscrito submetido à publicação.

ANEXO C.3 - Produção bibliográfica: Manuscrito em preparação 
Capítulo 1 


\section{INTRODUÇÃO GERAL}

Os gregos antigos usavam animais jovens em seus sacrifícios e notavam uma grande massa de tecido no tórax próximo ao coração, então concluíram que este órgão, o timo, seria a sede da alma. A origem da palavra timo [thymus, em latim e em inglês] é incerta, mas há fortes indícios de que seja derivada da palavra do grego antigo $\theta v \mu o \mathrm{~S}$, que é traduzida como alma, coração, coragem, mente, vontade ou propósito. A primeira descrição morfológica do timo foi feita por Galeno de Pergamum (130-200 a.C.), que se referu ao timo como um "órgão misterioso". Esta alcunha, de certa forma, permanece atual há mais de 2000 anos.

Por séculos o timo permaneceu um órgão enigmático e com funções desconhecidas. Em meados do século XX, o reconhecido do timo como local de produção de linfócitos foi bem estabelecido (Billingham et al., 1956; Gowans et al., 1961). Entretanto, embora se soubesse que o timo era um órgão produtor de linfócitos, os imunologistas não acreditavam que este tivesse alguma função imunológica, pois as principais características de resposta imune, como a plasmocitopoiese e a formação de centros germinativos, não eram observadas no timo de animais normais após a imunização. Em 1956, os linfócitos circulantes foram divididos em células T e B, depois que Glick et al. identificaram a bursa de Fabricius como a fonte de células produtoras de anticorpos.

Muitas questões a respeito da embriologia, anatomia, fisiologia, patologia e significado clínico do timo persistiram até 1961, quando a competência imunológica do timo e o sei papel fundamental para o estabelecimento e desenvolvimento do sistema imune normal foi demonstrado inequivocamente por e Muller (1961). O timo foi o último dos principais órgãos do corpo a ter as suas funções desvendadas. Entretanto, muitos dos seus segredos continuam por serem esclarecidos. Alguns dos mais recentes avanços nas diversas áreas da biologia do timo, especialmente nos últimos 10 anos, incluem a organogênese do timo, a regulação transcricional que induz à escolha/decisão do tipo celular que se desenvolverá no ambiente 
intratímico, e a migração regulada por quimiocinas de precursores de células $\mathrm{T}$ através dos diferentes microambientes tímicos.

\subsection{Histogênese do timo}

O timo é o primeiro órgão linfoide a se desenvolver durante a ontogênese. No ser humano, os primórdios de tecido tímico surgem no final da quinta semana da vida embrionária. $\mathrm{O}$ par de rudimentos epiteliais se origina bilateralmente a partir do endoderma do terceiro par de bolsas faríngeas, na porção anterior do tubo digestivo; penetra no mesoderma e é cercado por células mesenquimais residentes, derivadas da crista neural (Nishino et al., 2006; Rodewald, 2008). O mesênquima dá origem a estruturas tímicas como cápsula, septos e células perivasculares. A interação entre as células epiteliais e o mesênquima é essencial para o sucesso do desenvolvimento e função do timo (Owen et al., 2000).

Durante a oitava semana de vida intrauterina, o par de tecidos tímicos perde a conexão com a faringe e migra para o local definitivo, a região ântero-superior do mediastino, onde se funde para formar um único órgão bilobado. Cada lobo tem, individualizados, o suprimento sanguíneo, a drenagem linfática e a inervação. Por volta da décima semana de desenvolvimento embrionário, quando a vascularização do timo já está formada, o interstício entre as células epiteliais se torna colonizado por células-tronco hematopoiéticas precursoras dos timócitos (linfócitos $T$ intratímicos). Estas células indiferenciadas migram do saco vitelino e fígado do embrião, e alcançam o timo, através da corrente sanguínea, como resultado de sinais quimiotáticos induzidos continuamente pelo estroma tímico. Na décima segunda semana, os numerosos lóbulos tímicos, medindo entre 0,5 e 2,0 mm de diâmetro, já apresentam as regiões cortical e medular bem definidas. Após a colonização inicial por células-tronco, o timo cresce rapidamente e pode atingir o maior tamanho (entre 15,0 e 20,0 g em média), em relação à massa total do corpo, antes do nascimento ou nos primeiros meses de vida (Nishino et al., 2006). 


\subsection{Estrutura e função do timo}

O timo está localizado no tórax, imediatamente atrás da extremidade superior do osso esterno, sobre o coração e grandes vasos; possui dois lobos envolvidos por uma cápsula delgada, que penetra no órgão através de prolongamentos ou septos e, ao se unirem, dividem o órgão em pequenos lóbulos. A parte periférica de cada lóbulo, denominada córtex, é formada por tecido linfoide denso e contem a maioria dos timócitos relativamente imaturos, enquanto a porção central, ou medula, é constituída por tecido linfoide frouxo e contem timócitos maduros (Figura 1). $\mathrm{Na}$ medula estão localizadas estruturas típicas do timo, os corpúsculos de Hassall, cuja origem, natureza e funções são ainda pouco conhecidas. A região entre o córtex e a medula (córtico-medular) é caracterizada pela abundancia de vasos sanguíneos (Nishino et al., 2006; Razzani et al., 2008).

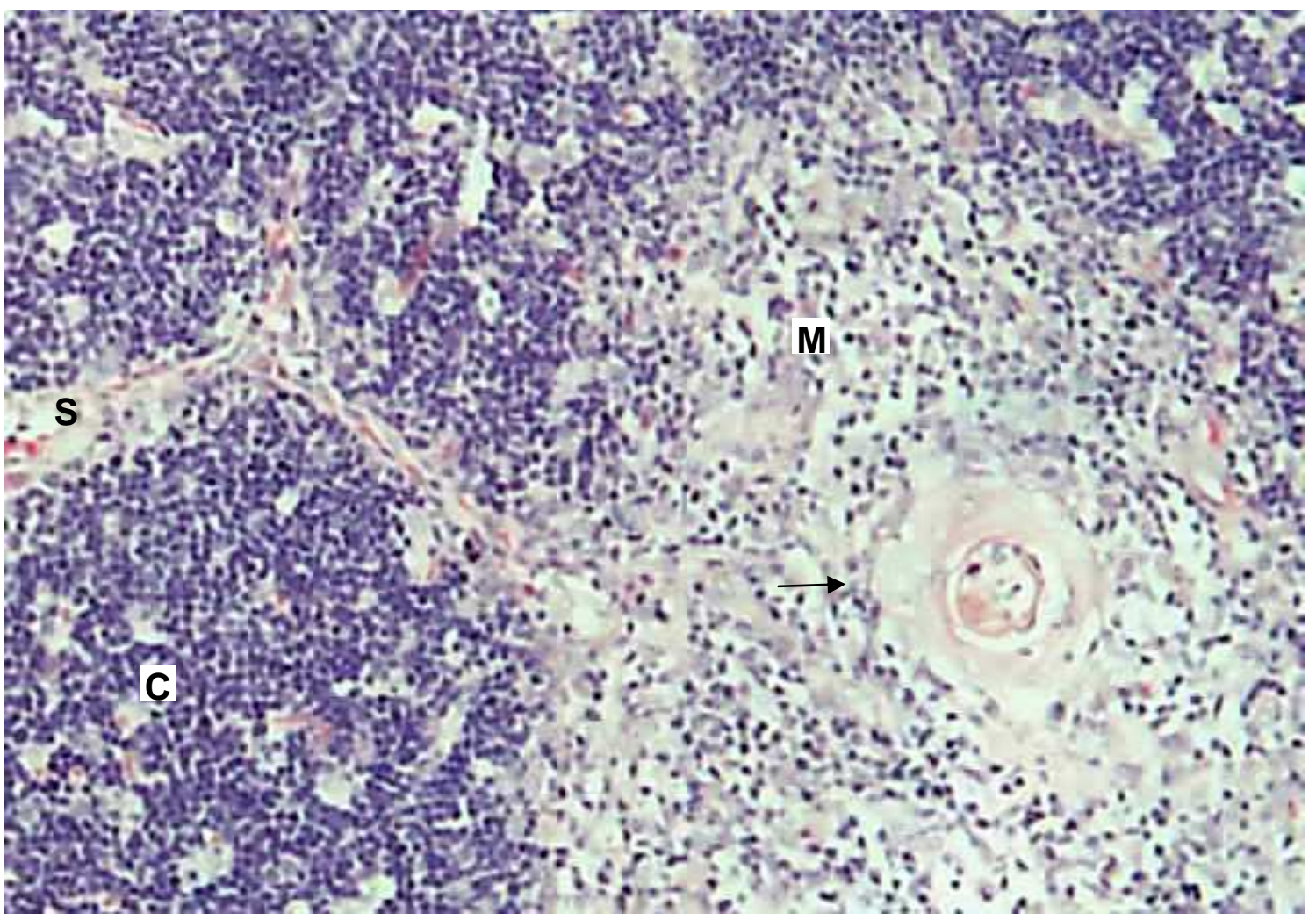

Figura 1. Corte histológico de timo humano corado pelo método Hematoxilina-Eosina. A região cortical $(\mathrm{C})$ apresenta maior densidade de células do que a região medular (M) tímica, onde estão localizados os corpúsculos de Hassall (seta). Septo (S). Aumento de 100x. 
O timo oferece o ambiente adequado para a timopoiese, caracterizada pelos processos de comprometimento, migração, proliferação, diferenciação e seleção de linfócitos T a partir de CTH precursoras. A timopoiese é um processo complexo e altamente dinâmico, que necessita de interações recíprocas (crosstalk) entre timócitos e células do estoma tímico, como células epiteliais, macrófagos, células dendríticas e fibroblastos. Assim, as CTH pluripotentes, oriundas da medula óssea, entram no timo através de vênulas pós-capilares localizadas na junção córticomedular, se deslocam em direção à região subcapsular, externa ao córtex, onde recebem sinais, não antigênicos, e dão início à primeira proliferação. 0 desenvolvimento dos timócitos avança concomitantemente com a migração destas células através de diferentes microambientes intratímicos, desde a região subcapsular, atravessando o córtex, até chegarem à medula tímica como linfócitos $\mathrm{T}$ maduros. No decorrer desta jornada, os timócitos expressam as moléculas que compõem o TCR e são submetidos a vários processos de verificação (checkpoint) e seleção, que levam grande parte dessas células à morte por apoptose (morte celular pré-programada por ativação de endonucleases endógenas, que determinam a fragmentação do DNA).

Durante a ontogenia dos linfócitos $\mathrm{T}$, ocorrem modificações sequenciais intensas das moléculas expressas na superfície celular, como: CD117, CD44, CD25, CD4 e CD8 (Godfrey et al., 1993). De acordo com estas alterações fenotípicas, os timócitos podem ser classificados em 6 estágios de diferenciação. Nos estágios mais precoces, os timócitos não expressam CD4 e CD8, sendo denominados duplonegativos (DN): DN1 (CD117 $\left.{ }^{+} \mathrm{CD} 44^{+} \mathrm{CD} 25^{-}\right)$, DN2 $\left(\mathrm{CD} 117^{+} \mathrm{CD} 44^{+} \mathrm{CD} 25^{+}\right)$, DN3 $\left(\mathrm{CD} 117^{-} \mathrm{CD}^{-} 4^{-} \mathrm{CD}^{+} 5^{+}\right)$e DN4 (CD117 $\left.{ }^{-} \mathrm{CD} 44^{-} \mathrm{CD} 25^{-}\right)$. No quinto estágio, os timócitos são $\mathrm{CD}^{+} \mathrm{CD}^{+}$duplo-positivos (DP) (Ciofani et al., 2006); e no último estágio, simples-positivos (SP), expressam apenas uma destas moléculas. Esta classificação pode auxiliar no estudo das populações de timócitos em desenvolvimento. 


\subsection{Diversidade e seleção de linfócitos T}

Há aproximadamente 500 milhões de anos, nos primórdios da evolução dos vertebrados mandibulados, o timo surgiu junto com o aparecimento de linfócitos capazes de expressar uma grande diversidade de receptores para reconhecimento de antígenos, baseados na recombinação de DNA (recombinação somática) (Litman et al., 2005; Cooper e Alder, 2006).

No timo, um extraordinário repertório de clones de linfócitos T é gerado através de rearranjos aleatórios dos segmentos gênicos $\mathrm{V}$ (variable), D (diversity) e J (joining), dando origem ao polimorfismo das moléculas heterodiméricas de TCR $\alpha \beta$ ou $\gamma \delta$, expressas na superfície de cada célula T. As recombinações dos segmentos gênicos são mediadas e altamente reguladas pelas proteínas RAG (recombinaseactivating gene) 1 e 2, com objetivo de maximizar a heterogeneidade das moléculas de TCR (Oettinger et al., 1990). Esta diversidade garante que qualquer antígeno estranho seja reconhecido por algum linfócito $\mathrm{T}$ efetor, assegurando o início uma resposta imune específica.

O desenvolvimento dos timócitos é altamente regulado para garantir a geração de células T contendo o TCR funcional e incapaz de reconhecer, como estranhas, proteínas do próprio organismo (autoantígenos). O primeiro processo de verificação, chamado de seleção $\beta$, acontece com timócitos corticais DN3 e 4 após a expressão do complexo pré-TCR (cadeia de TCR $\beta$ ligada covalentemente a uma cadeia de pré-TCR $\alpha$ invariante e CD3) (Levelt et al., 1993a, b). Assim, as células contendo arranjos produtivos de TCR $\beta$ (ou TCR $\gamma$ e $\delta$ ) se livram da apoptose, seguem a diferenciação para DP $\mathrm{CD}^{+} \mathrm{CD}^{+}$e proliferam. A seleção positiva acontece logo em seguida, ainda no córtex tímico, e assegura o desenvolvimento dos timócitos DP que expressam a molécula completa de TCR útil, capaz de se ligar adequadamente às moléculas de classe I ou II do MHC (major histocompatibility complex), presentes na membrana de células epiteliais intratímicas. Em paralelo com a seleção positiva, acontece o comprometimento alternativo em linhagens SP CD4 (célula T auxiliar) ou CD8 (célula T citotóxica) (Takahama, 2006; Husebye et al., 2008). No último processo de verificação, denominado de seleção negativa ou tolerância central, os timócitos SP são avaliados quanto à capacidade de reconhecimento a peptídeos do 
próprio organismo apresentados por algumas células epiteliais e células dendríticas medulares. Assim, os timócitos que reagem com alta afinidade contra autoantígenos, sofrem apoptose; e aqueles que reagem com afinidade adequada, sobrevivem e migram para a periferia, através das vênulas córtico-medulares, como linfócitos T maduros hábeis a exercer suas funções efetoras (Mathis e Benoist, 2009). Mais de 95\% dos timócitos sofrem apoptose antes de chegar à fase madura, devido principalmente aos arranjos mal sucedidos das cadeias de TCR e aos processos de seleção positiva e negativa (Gill et al., 2003; Takahama, 2006; Rezzani et al., 2008).

\subsection{Epitélio tímico}

As células epiteliais do timo (CET) compõem um ambiente especial, capaz de: recrutar células progenitoras hematopoiéticas da circulação, direcionar e controlar o comprometimento e a diferenciação de timócitos, e selecionar o repertório de TCR. Baseado na localização anatômica, o epitélio tímico é comumente dividido em dois compartimentos: cortical e medular.

As origens e relações das CET durante o desenvolvimento embrionário permanecem em discussão. Sabe-se que o epitélio tímico se desenvolve a partir do terceiro par de bolsas faríngeas, mas ainda há controvérsias quanto à participação do ectoderma do terceiro par de fendas faríngeas. A hipótese da origem dupla sugere que as CET corticais são geradas do ectoderma, enquanto as CET medulares derivam do endoderma (Cordier e Heremans, 1975; Cordier e Haumont, 1980; Manley e Blackburn, 2003). Entretanto, o modelo mais aceito indica que as CET, de ambos os compartimentos, têm um progenitor comum derivado apenas do endoderma (Manley e Blackburn, 2003; Gordon et al., 2004).

Ao longo da vida, a homeostase do epitélio tímico é mantida através da contínua autorrenovação de "células-tronco epiteliais" - que ainda estão por serem identificadas no pool de células-tronco ou progenitoras intratímicas - e da diferenciação de novas CET. A dinâmica interação entre progenitores epiteliais e outros tipos de células intratímicas, como células mesenquimais e progenitores linfoides, é fundamental para o processo de renovação epitelial. 
Análises fenotípicas e ultraestruturais têm mostrado uma diversidade de CET dentro de cada compartimento tímico, com características diferentes e funções pouco conhecidas. De acordo com as observações da morfologia ultraestrutural, as CET podem ser divididas em 6 tipos (van de Wijngaert, 1984; Schuurman et al., 1997):

a) CET tipo I - Subcapsular e perivascular:

Em essência, as CET tipo I separam o parênquima tímico do tecido conectivo do órgão. Contornam toda a região subcapsular e os septos; e cercam a túnica adventícia dos vasos sanguíneos da região córtico-medulares. As junções oclusivas entre estas células refletem sua função como uma barreira que isola os timócitos em desenvolvimento dos tecidos conectivos do órgão.

b) CET tipo II - Córtex:

Estão localizadas no córtex tímico e apresentam um grande núcleo, que cora levemente por HE (método de coloração Hematoxilina-Eosina) devido a abundancia de eucromatina. Este aspecto nuclear permite que a célula seja facilmente identificada ao microscópio óptico. A microscopia eletrônica de transmissão (MET) revela desmossomos, que ligam longos processos citoplasmáticos de células adjacentes. Diferente das CET tipo I, as CET tipo II expressam as moléculas de MHC I e MHC II.

c) CET tipo III - Córtex profundo e córtico-medular:

As CET III estão localizadas na fronteira entre o córtex e a medula, apresentam núcleo eletrodenso e, como as CET tipo II, expressam moléculas de $\mathrm{MHC}$ de classes I e II. A MET revelara junções oclusivas entre os processos citoplasmáticos de células adjacentes. Como as CET tipo I, as CET tipo III criam uma barreira funcional, mas neste caso entre o córtex e a medula. 
d) CET tipo IV - Córtex profundo e córtico-medular:

Estão localizadas próximas às células do tipo III. Apresentam junções oclusivas entre os prolongamentos citoplasmáticos de células dos tipos III e IV adjacentes. Em cooperação com as células do tipo III, estas criam uma barreira na junção córtico-medular.

e) CET tipo V - Medula:

Assim como as CET corticais do tipo II, as CET medulares do tipo V apresentam desmossomos interligando os curtos processos citoplasmáticos de células adjacentes. Formam a rede epitelial da medula $e$ compartimentaliza grupos de timócitos. O núcleo destas células é densamente corado, como o núcleo de timócitos.

f) CET tipo VI - Corpúsculos de Hassall:

Os corpúsculos de Hassall são massas isoladas formadas por CET tipo VI concentricamente arranjadas. Estas células epiteliais medulares possuem núcleo achatado e são interligadas por desmossomos. Estudos de MET revelaram a presença de grânulos de queratohialina ligados a filamentos citoplasmáticos intermediários, e gotas de lipídeo. O centro de um corpúsculo tímico pode exibir evidências de queratinização.

Classicamente, os corpúsculos de Hassall são descritos como estruturas únicas, com tamanho e número variável, antigenicamente distintas e com frequente presença de modificações degenerativas no interior, como: necrose, detritos celulares, calcificação e alterações císticas (Raica et al., 2006).

Uma função recentemente atribuída ao epitélio dos corpúsculos de Hassall é a expressão de moléculas de TSLP (thymic stromal lymphopoietin), que promovem a ativação das células dendríticas medulares capazes de induzir a diferenciação de células $\mathrm{T}$ regulatórias (Treg) naturais $\mathrm{CD}^{+} \mathrm{CD}^{+}{ }^{+} \mathrm{Foxp}^{+}$(Watanabe et al., 2005; Wang e Xing, 2008). 


\subsection{Involução do timo}

Em mamíferos, o tecido funcional do timo diminui com a idade. No homem, a perda de áreas de células epiteliais, denominada atrofia tímica, começa já na primeira infância, com taxas de 3\% ao ano até a fase adulta média (35-45 anos), e segue diminuindo a $1 \%$ ao ano até o fim da vida (Steinmann et al., 1985). Em condições fisiológicas normais, o tamanho do timo permanece inalterado durante toda a vida (média de $19,5 \mathrm{~cm}^{3}$ ). Isto se deve à expansão do espaço perivascular, do tecido conectivo e dos corpúsculos de Hassall, bem como o surgimento de adipócitos a partir da puberdade (Figura 2) (Steinmann et al., 1985). A perda constante de epitélio tímico resulta na diminuição progressiva da timopoiese, com consequente redução da emigração de linfócitos T naïve para a periferia (Steinmann et al., 1985; Haynes et al., 2000; Hale, 2004; Lynch et al., 2009).

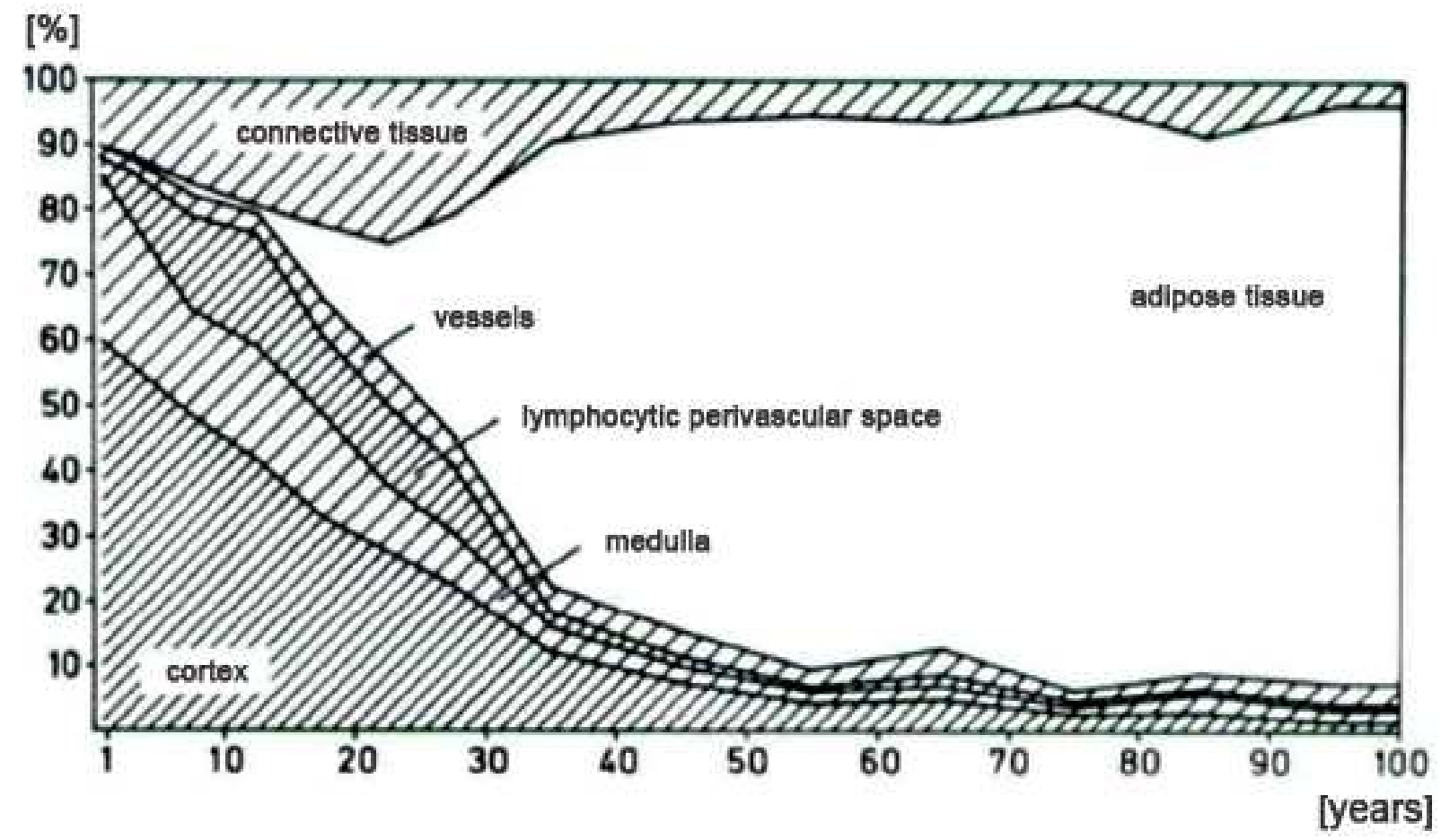

Figura 2. Mudanças no volume relativo (\%) dos compartimentos tímicos em relação à idade do indivíduo.

FONTE: Steinmann et al. (1985). 
Na maioria das circunstâncias, o declínio do timo tem mínimas consequências sobre indivíduos saudáveis, entretanto, com o avanço da idade, a reduzida eficácia do sistema imune tem ligação etiológica direta com o aumento de doenças como infecções oportunistas, doenças autoimunes e câncer. Além disto, observa-se em adultos uma grande dificuldade de restaurar a função do sistema imune após danos provocados por quimioterapia, exposição à radiação ionizante e infecções graves (por exemplo, pelo vírus HIV), podendo conduzir o indivíduo à morbidade e, frequentemente, à morte.

\subsection{Timectomia}

A razão mais comum para a remoção cirúrgica do timo é a necessidade de acesso ao coração ou grandes vasos do tórax de crianças com cardiopatias congênitas submetidas a cirurgias para correção. Estima-se que uma em cada 100 crianças nasça com algum defeito cardíaco congênito (Hoffman e Kaplan, 2002), e em mais de $50 \%$ dos casos há necessidade de cirurgia invasiva para correção do defeito - em alguns casos, no paciente ainda recém-nascido e, em outros, mais tarde.

Nos últimos 30 anos, a cirurgia cardíaca aberta em neonatos tem se tornado um procedimento cada vez mais seguro e frequentemente executado. Não há relatos clínicos apontando distúrbios imunes, tais como imunodeficiências, em decorrência da timectomia nestes pacientes (Rubinstein et al., 1976; Appay et al., 2010). Entretanto, pacientes timectomizados antes dos 15 dias de vida, avaliados com idades entre 18 e 26 anos, apresentam alterações imunológicas periféricas

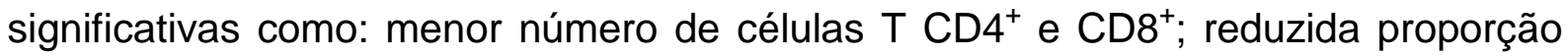
de linfócitos $T$ naïve recém saídos do timo, menos TREC (TCR recombination excision circle); acúmulo de populações de células $T$ de memória oligoclonais; marcadores de inflamação aumentados (Sauce et al., 2009). Estes dados indicam sinais de envelhecimento prematuro do sistema imune relacionados à falta de produção de novos linfócitos T pelo timo. 
Aparentemente, o repertório de linfócitos $T$ produzido antes do nascimento, e até a data da timectomia, é suficiente para suportar as necessidades do organismo até a fase adulta jovem. Entretanto, a manutenção da atividade tímica é necessária para prevenir o desenvolvimento prematuro de um fenótipo imune de risco, que pode ter consequências graves na fase adulta mais madura (aguardando dados concretos) (Sauce et al., 2009; Zlamy e Prelog, 2009).

\subsection{Síndrome DiGeorge e transplante de timo}

O fenótipo da síndrome DiGeorge (SDG) é resultado de uma desordem congênita provocada por microdeleção monoalélica de um ou vários genes adjacentes, localizados no cromossomo humano 22q11.2. Afeta um a cada 30004000 nascidos vivos, sendo a mais frequente deleção cromossômica conhecida (Botto et al., 2003; Öskarsdóttir et al., 2004). As manifestações clínicas e a gravidade da doença são variáveis, com características cognitivas, comportamentais e físicas alteradas. Classicamente, a doença se caracteriza pela presença de dismorfismos faciais, defeitos cardíacos e dos grandes vasos, hipoplasia ou aplasia do timo e da paratireoide (Ryan et al., 1997). Os órgãos afetados se derivam do terceiro e do quarto par de bolsas faríngeas, e as manifestações fenotípicas são o resultado de defeitos no desenvolvimento embrionário destas estruturas.

De acordo com a condição clínica, a SDG pode ser classificada em dois tipos: parcial e completa. A SDG parcial é mais frequente e os pacientes apresentam um grau variável de hipoplasia tímica e paratireoidea, enquanto os portadores da SDG completa apresentam aplasia destes tecidos.

A maioria dos pacientes com SDG apresenta imunodeficiência de menor grau, e comumente é diagnosticada com infecções como sinusite, otite média, bronquite e pneumonias de repetição (Jawad et al., 2001). A ocorrência de imunodeficiência se deve à hipoplasia tímica, observada na maioria dos casos. Entretanto, em alguns destes pacientes, a imagem tímica não é vista na radiografia de tórax (Ryan et al., 1997; Sullivan, 2004). Este fato tem levantado à hipótese de que haja resquícios de 
tecido tímico ou timos ectópicos, funcionais, na região do pescoço dos pacientes acometidos, que geralmente apresentam linfócitos $T$ maduros na periferia.

Crianças acometidas com a forma mais rara e severa da doença, a SDG completa, apresentam total ausência de tecido tímico, resultando em imunodeficiência grave, causada pela falta de linfócitos T. Estes pacientes tipicamente morrem de infecção antes de completar dois anos de vida, a menos que haja reconstrução imune através de um transplante, bem sucedido, de tecido tímico halogênico. Neste caso, o timo a ser transplantado é proveniente de lactentes, de até nove meses de idade, submetidos a cirurgias cardíacas. Fatias de timo são inseridas no músculo quadríceps do paciente com SDG, em cirurgia aberta (Hudson et al., 2007). Os capilares do músculo invadem o tecido enxertado e após dois meses já se observa timopoiese a partir de células-tronco migrantes da medula óssea do paciente receptor, no estroma tímico do doador. A partir do terceiro mês, linfócitos T são encontrados na circulação sanguínea (Markert et al., 1997; Hudson et al., 2007; Markert et al., 2010).

A complexa maquinaria do timo, com todas as implicações para 0 funcionamento apropriado do sistema imune, bem como as suas falhas - que podem levar a imunodeficiências e patologias autoimunes -, contribui para que este seja um campo de pesquisa fascinante. Assim, uma compreensão adicional dos mecanismos moleculares e celulares que regulam o desenvolvimento dos timócitos é sempre bem-vinda.

Neste trabalho, foram estudados os padrões de expressão de moléculas fundamentais para o sucesso da diferenciação e da seleção de linfócitos T no timo humano, como as proteínas que compõem a via de sinalização celular Notch e AIRE (autoimmune regulator), respectivamente. O Capítulo 2 se refere à análise da expressão de AIRE em timos de crianças com cardiopatias congênitas, e que tiveram o timo removido (timectomia) durante cirurgia cardíaca. No Capítulo 3 apresentamos a avaliação da expressão da proteína AIRE em timos provenientes de crianças com síndrome de Down, mostrando uma diminuída proporção de células $\mathrm{AIRE}^{+}$neste grupo de pacientes, que frequentemente apresenta autoimunidade. No 
Capítulo 4 está descrita a distribuição de ligantes e receptores Notch no timo humano. 
CAPÍtULO 2 


\section{ESTUDO DA EXPRESSÃO DAS PROTEÍNAS AIRE E FOXP3 NO TIMO HUMANO}

\subsection{Introdução}

A tolerância imunológica tem sido um dos enigmas que mais fascina os imunologistas há muitas décadas. O sistema imune consegue distinguir elementos constituintes do próprio corpo e invasores estranhos; tolerar o próprio e combater invasores. Classicamente, os mecanismos de tolerância têm sido agrupados em duas categorias: central e periférica.

A tolerância central regula os linfócitos em desenvolvimento nos órgãos linfoides primários, e os principais mecanismos de regulação celular são a deleção clonal e o desvio clonal de células autorreativas. No timo, a expressão de AIRE (autoimmune regulator) constitui um elemento essencial para o processo de seleção negativa dos linfócitos $T$ e, consequentemente, para manter o equilíbrio do sistema imune (Mathis e Benoist, 2009).

O gene AIRE está localizado no cromossomo 21q22.3, é composto por 14 éxons e codifica uma proteína de 545 aminoácidos, com massa molecular de 58 $\mathrm{kDa}$. Este gene foi identificado, há pouco mais de 10 anos, em estudos realizados com pacientes portadores de uma doença autoimune rara, a APECED (Autoimmune Polyendocrinopathy, Candidiasis, Ectodermal Dystrophy) (Finnish-German APECED Consortium, 1997; Nagamine et al., 1997), provocada por mutações na sequência genética de AIRE. Mais de 60 distintas mutações já foram identificadas no gene AIRE de diferentes pacientes com APECED (Mathis e Benoist, 2009). As manifestações clínicas da APECED são amplas e variáveis, com a presença de candidíase mucocutânea crônica (em 100\% dos casos), associada a múltiplas endocrinopatias autoimunes, como: hipoparatireoidismo (79-93\%), hipoadrenalismo (70-73\%), falência ovariana ou testicular (43-50\%), hipotireoidismo (10\%), diabetes mellitus insulino-dependente (2-12\%) e hipofisite (7\%) (Ahonen et al., 1990; Betterle et al., 1998; Perheentupa, 2006; Husebye et al., 2009). Outros tecidos do corpo 
podem ser acometidos causando: hepatite autoimune crônica (12-20\%), gastrite autoimune, alopecia, vitiligo e anemia perniciosa (Husebye et al., 2009). Até o momento, as diferentes mutações de AIRE não foram associadas, de forma convincente, com manifestações específicas da doença.

A proteína AIRE possui características estruturais que a configuram como um regulador transcricional e proteína associada à cromatina (Figura 3), como a presença de dois domínios PHD (plant homeodomain domain) - que funcionam como fator de transcrição - e um domínio SAND (Sp100, AIRE, NucP41/75, DEAF1), que em outras proteínas confere atividades ligadas ao DNA (Aasland et al., 1995; Bottomley et al., 2001). Além disto, AIRE contem um domínio CARD (caspaserecruitment domain), necessário para a atividade de transativação da expressão de genes alvo (Ferguson et al., 2008) e para o recrutamento e ativação de caspase durante o processo de apoptose celular (Mathis e Benoist, 2009). AIRE também apresenta atividade de E3 ligase, indicando que a ubiquitinação de proteínas é uma das funções desta molécula na regulação transcricional (Uchida et al., 2004).

AIRE CARD/HSR SAND

\section{PHD1} PHD2

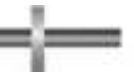

Figura 3. Representação esquemática da estrutura da proteína AIRE humana. A molécula de AIRE é composta por vários domínios: CARD (caspase recruitment domain), aminoácidos 8-96; NLS (nuclear localization signal), aminoácidos 113-133; domínio SAND (Sp100, AIRE, NucP41/75, DEAF-1), aminoácidos 181-280; PHD (plant homeodomain type zinc-finger), aminoácidos 299-340 e 434-475; PRR (proline-rich region), aminoácidos 350-407.

FONTE: Mathis e Benoist (2009).

Após a descoberta de AIRE, surgiram várias hipóteses sobre a maneira como esta molécula poderia atuar no controle da autoimunidade: promovendo a organização do estroma tímico (Zuklys et al., 2000); regulando a resposta de linfócitos $B$ e $T$ periféricos a estímulos antigênicos (Finnish-German APECED 
Consortium, 1997); provocando a apoptose de células estromais e, desta forma, promovendo a apresentação cruzada de antígenos próprios (Peterson et al., 1998); controlando a tolerização de timócitos (Nagamine et al., 1997); e promovendo a diferenciação de células Treg CD4 ${ }^{+} \mathrm{CD}_{25}{ }^{+}$Foxp3 $^{+}$(Peterson et al., 1998) a partir de timócitos autorreativos.

O papel de AIRE como fator transcricional, capaz de ativar a expressão de numerosos genes (200-1200) (Anderson et al., 2002; Gotter et al., 2004), está bem estabelecido, entretanto, os mecanismos envolvidos nesta função continuam pouco conhecidos (Mathis e Benoist, 2009).

No timo, a proteína AIRE é expressa por algumas CET tipo V, localizadas na região medular, e funciona como o fator transcricional responsável por regular, de maneira dose-dependente, a expressão ectópica de uma série de proteínas restritas a determinados tecidos periféricos - no ambiente tímico (Liston et al., 2004; Rizzi et al., 2006; Mathis e Benoist, 2009), como: insulina (pâncreas) e tireoglobulina (tireoide), entre outras. As CET AIRE' expressam moléculas de $\mathrm{MHC}$ e funcionam como células apresentadoras de antígenos, expondo os peptídeos do próprio organismo (ou autoantígenos) ao TCR dos timócitos em fase final do desenvolvimento. Assim, os timócitos, cujo TCR interage com autoantígenos de maneira moderada, se tornam maduros e seguem para a periferia. Por outro lado, os timócitos que reagem de forma inadequada podem sofrer apoptose ou desvio clonal.

O desvio clonal de timócitos autorreativos leva à diferenciação de células Treg naturais $\mathrm{CD}^{+} \mathrm{CD}^{+} 5^{+} \mathrm{Foxp}^{+}$(Jordan et al., 2001; Apostolou et al., 2002; Aschenbrenner et al., 2007), e tem a participação ativa e fundamental de células dendríticas da medula tímica. Estas células não expressam AIRE, mas são capazes de sequestrar e apresentar autoantígenos produzidos pelas células epiteliais AIRE $^{+}$ adjacentes (Methis e Benoist, 2007). O reconhecimento do timócito a um autoantígeno, apresentado por uma célula dendrítica, parece ser crucial para este processo, entretanto, até o momento, a participação de AIRE na indução de células Treg naturais permanece incerta. Estudos realizados em camundongos mostraram que a ausência de AIRE não altera o número total de células Treg $\mathrm{CD}_{2} 5^{+} \mathrm{Foxp}^{+}$na periferia (Liston et al., 2003; Anderson et al., 2005). Por outro lado, Kekalainen et al. 
(2007) encontraram proporções mais baixas de células Treg circulantes em pacientes com APECED.

As células Treg naturais são originadas no timo e desempenham um papel crucial na prevenção de autoimunidade, suprimindo ativamente células $T$ autorreativas na periferia, bem como respostas imunes inapropriadas ou excessivas. A síndrome IPEX (Immunedysregulation, Polyendocrinopathy, Enteropathy, Xlinked) é uma desordem rara causada por mutações no gene FOXP3, resultando na falha do desenvolvimento de células Treg naturais (Powell et al., 1982). Pacientes com IPEX são acometidos por uma autoimunidade grave, caracterizada por manifestações de enteropatia autoimune, dermatite, diabetes tipo I, tireoidite (van der Vliet e Nieuwenhuis, 2007), e, frequentemente, morrem antes do segundo ano de vida.

\subsubsection{Objetivos}

Os principais objetivos deste estudo foram:

- analisar, através de ensaios de imunohistoquímica, a expressão da proteína AIRE em timos humanos;

- analisar a expressão da proteína Foxp3 em timos humanos.

\subsection{Material e métodos}

\subsubsection{Coleta e armazenamento dos timos humanos}

Os timos utilizados neste estudo são provenientes de crianças com cardiopatias congênitas, submetidas a cirurgias corretivas no Hospital do Coração Associação do Sanatório Sírio, São Paulo. A timectomia, total ou parcial, é realizada rotineiramente com intuito de expor o tecido cardíaco a ser tratado cirurgicamente, devido à grande massa tímica encontrada sobre o coração e grandes vasos da base 
de crianças. Nenhum tecido foi removido com o intento apenas de realizar pesquisa científica. Todos os espécimes coletados tiveram o consentimento prévio dos pais ou responsáveis pelos menores (modelo do termo de consentimento no ANEXO A), bem como a aprovação das Comissões de Ética do Hospital do Coração e do Instituto de Ciências Biomédicas - Universidade de São Paulo, ambos devidamente documentados. Logo após a remoção do timo, fragmentos do tecido (5 a $10 \mathrm{~mm}$ de diâmetro) foram coletados em $10 \mathrm{~mL}$ de formalina $10 \%$ tamponada ( $\mathrm{pH} 7,4)$, por um período mínimo de 24 horas. Os tecidos fixados foram enviados ao Laboratório de Moléstias Transmissíveis do Departamento de Patologia da Faculdade de Medicina da Universidade de São Paulo (FMUSP), para o procedimento de inclusão em parafina.

\subsubsection{Cortes histológicos, desparafinização e hidratação dos tecidos}

Os fragmentos tímicos preservados em parafina foram submetidos a secções ultrafinas, realizadas em micrótomo ajustado para fazer cortes com $3 \mu \mathrm{m}$ de espessura. Os tecidos cortados foram coletados em lâminas eletricamente carregadas e incubados em estufa com temperatura entre 60 e $70{ }^{\circ} \mathrm{C}$, por um tempo mínimo de 1 hora. Após a adesão dos tecidos às lâminas, estes recebem tratamento para desparafinização e hidratação, que consistem em: imergir as lâminas contendo os tecidos em xilol, 2 vezes (dois diferentes recipientes contendo xilol) de 10 minutos em cada recipiente, para a remoção da parafina; e para a hidratação, mergulhar as lâminas várias vezes, por 30 segundos, em cada recipiente de uma sequência de soluções de álcool etílico em diferentes concentrações (álcool absoluto 2 vezes, álcool 95\% 2 vezes, álcool 70\%) e água destilada.

\subsubsection{Coloração de cortes tímicos pelo método de HE}

Para avaliar a integridade das características histológicas e funcionais de cada compartimento tímico - como a presença de corpúsculos de Hassall, 
timopoiese e distribuição normal dos timócitos - cortes histológicos de cada timo foram colorados pelo método de Hematoxilina-Eosina. A hematoxilina (corante básico) reage com estruturas aniônicas das células, como heterocromatina, nucléolo, RNA ribossômico; a eosina (corante ácido) reage com componentes celulares catiônicos, como citoplasma, filamentos citoplasmáticos e fibras extracelulares.

O procedimento para coloração por HE foram realizado em uma sequência ininterrupta de incubações. Assim, resumidamente, as lâminas contendo cortes já desparafinizados e hidratados foram: imersas por 8 segundos em solução de hematoxilina, previamente filtrada; lavadas em água corrente até tirar o excesso do corante; mergulhadas rapidamente $2-3$ vezes no diferenciador (álcool $70 \%+1 \%$ de $\mathrm{HCl}$ ); lavadas em água morna por 5 minutos para revelar os núcleos; mergulhadas 2-3 vezes em eosina 1\%, preparada imediatamente antes do uso; imediatamente lavadas em água destilada; mergulhadas 3-5 vezes na sequência de álcool (álcool 70\%, álcool 95\%, álcool absoluto) e xilol.

As lâminas foram montadas com uma gota de resina Permount (Fisher Scientific) e uma lamínula sobre o tecido corado. Após secar em temperatura ambiente os tecidos foram observados ao microscópio de luz branca em vários aumentos. A hematoxilina cora as estruturas em azul e a eosina em vermelho ou rosa.

\subsubsection{Imunohistoquímica}

Imunohistoquímica é uma técnica utilizada para a localização de proteínas, ou antígenos, em cortes histológicos de tecidos, através do uso de anticorpos específicos (reação antígeno-anticorpo). A proteína alvo pode ser visualizada após a reação com marcadores fluorescentes ou cromogênicos, ao microscópio de luz ultravioleta ou luz branca, respectivamente. Ambos os métodos foram aplicados neste estudo. 


\subsubsection{Marcações simples}

Após a desparafinização e hidratação, os cortes histológicos foram submetidos aos seguintes passos:

a) Tratamento para recuperação antigênica:

A fixação do tecido em formalina promove ligações entre grupos aminos e a formação de pontes de metileno entre os aminoácidos de uma proteína, ou de proteínas adjacentes. Estas múltiplas ligações podem impedir o acesso de anticorpos aos epítopos alvo. O desmascaramento dos antígenos, ou recuperação antigênica, pode ser realizado com o uso de calor.

Para a recuperação antigênica, os tecidos foram imersos em solução de Tris-EDTA (Tris 0,01M, EDTA 0,001M, pH 8,0) e submetidos a fervura por 20 minutos em micro-ondas ajustado para 800 Watts de potência. Após o procedimento, os tecidos foram resfriados e lavados em água corrente por 10 minutos.

b) Bloqueio da peroxidase endógena:

Alguns tecidos, como as hemácias, produzem peroxidase endógena, que pode ser detectada, através do método de imunoperoxidase, provocando uma falsa reação antígeno-anticorpo.

Para bloquear a peroxidase endógena, os tecidos foram incubados em peróxido de hidrogênio $\left(\mathrm{H}_{2} \mathrm{O}_{2}\right)$ a $3 \%$, por 15 minutos, em temperatura ambiente e ao abrigo da luz. Após as incubações, os tecidos foram lavados com água corrente e, em seguida, com PBS (tampão salina-fosfato 0,01M $\mathrm{pH} 7,4)$, por 5 minutos, em temperatura ambiente.

c) Bloqueio de sítios de ligações inespecíficas:

A principal causa de reação inespecífica é a ligação, não imunológica, do anticorpo específico por forças eletrostáticas e hidrofóbicas em determinados sítios do corte de tecido.

Para bloquear sítios e evitar ligações inespecíficas do anticorpo, os 
tecidos foram incubados com a solução de bloqueio (PBS-BSA), ou seja, PBS contendo 5\% de albumina bovina (BSA), por 15 minutos, em temperatura ambiente.

d) Incubação com o anticorpo primário:

Após remoção da solução de bloqueio, cada amostra foi incubada com $50 \mu \mathrm{l}$ da solução contendo o anticorpo primário diluído em PBS, por 16-18 horas, a $4{ }^{\circ} \mathrm{C}$, em câmara úmida. As concentrações do s anticorpos foram previamente padronizadas com base inicial nas recomendações dos fabricantes dos anticorpos.

\section{Detecção através do método enzimático de imunoperoxidase}

a) Reação com o sistema de detecção:

Após incubação com o anticorpo primário, os tecidos foram lavados 3 vezes com PBS, por 5 minutos para cada lavagem, em temperatura ambiente. Para a detecção do anticorpo primário ligado ao antígeno no tecido, as amostras foram incubadas com os reagentes do kit "LSAB-HRP Universal" (DakoCytomation, Carpinteria, CA, USA), sendo: 30 minutos em estufa a 37 ${ }^{\circ} \mathrm{C}$ com $50 \mu \mathrm{l}$ do anticorpo secundário biotinilado; 3 vezes de 5 minutos com PBS para lavar, em temperatura ambiente; e mais 30 minutos a $37^{\circ} \mathrm{C}$ com o complexo de estreptavidina conjugada com peroxidase, formando o complexo biotina-estreptavidina-peroxidase. Em seguida, os cortes foram lavados novamente 3 vezes com PBS, por 5 minutos, em temperatura ambiente. Todas as incubações foram feitas em câmara úmida.

b) Revelação:

Os tecidos lavados foram incubados em tampão de revelação contendo $20 \mu \mathrm{l}$ do cromógeno $\mathrm{DAB}$ (3,3' diaminobenzidine) líquido para $1 \mathrm{~mL}$ de solução de substrato (kit Dako), segundo recomendação do fabricante. As marcações foram reveladas após cerca de 1 minuto de reação enzimática. 
Para cessar a reação, os tecidos foram lavados em água corrente por 10 minutos.

c) Montagem e observação das lâminas:

Após as revelações, os tecidos foram contracorados com hematoxilina de Mayer's (Dako) (núcleos corados em azul), lavados em água corrente por 10 minutos, desidratados, secos e, por último, montados com resina Permount (Fisher Scientific) e lamínula. As marcações, visualizadas na cor castanha, foram observadas ao microscópio óptico em vários aumentos e registradas fotograficamente.

\section{Detecção através de imunofluorescência}

a) Incubação com o anticorpo secundário fluorescente:

Para os ensaios de imunofluorescência, os tecidos previamente incubados com o anticorpo primário foram lavados 3 vezes com PBS, sendo 5 minutos para cada lavagem, e em seguida incubados com $50 \mu$ da solução contendo o anticorpo secundário conjugado FITC (Fluorescein isothiocyanate) diluído em PBS, por 45 minutos, ao abrigo da luz, em câmara úmida e temperatura ambiente. Os cortes foram lavados novamente com PBS, 3 vezes de 5 minutos, ao abrigo da luz. Os anticorpos secundários utilizados neste estudo foram: asno anti-coelho e cabra anti-rato, 2,0 $\mu \mathrm{g} / \mathrm{mL}$; asno anticabra, 4,0 $\mu \mathrm{g} / \mathrm{mL}$ (Santa Cruz Biotechnology, Inc., Santa Cruz, CA, USA).

b) Montagem e observação das lâminas:

Os tecidos receberam uma gota da solução contendo $1 \mathrm{~mL}$ de meio de montagem Vectashield (Vector Laboratories, Burlingame, CA, USA) para $1 \mu \mathrm{l}$ de DAPI (4',6 diamidino-2-phenylindole), e lamínula. As marcações foram analisadas e registradas fotograficamente ao microscópio de fluorescência (Leica DM5000 B), em diferentes filtros e aumentos (desde 50 até 650 vezes). 
A FITC emite fluorescência verde clara (excitação com 430-510 nm), e o DAPI marca o núcleo celular em azul (excitação com 320-400nm).

\subsubsection{Marcações duplas}

A técnica de marcação dupla foi utilizada para revelar dois antígenos diferentes em um mesmo corte de tecido.

Assim, resumidamente, após a revelação das marcações simples com 0 cromógeno DAB, os tecidos foram lavados com PBS e incubados com um segundo anticorpo primário. $\mathrm{O}$ anticorpo ligado ao antígeno alvo foi detectado pela técnica de imunofosfatase, através do kit "LSAB-AP Universal" (Dako), contendo um anticorpo secundário ligado a biotina, e um complexo de estreptavidina conjugada com fosfatase alcalina. As incubações foram feitas nas mesmas condições usadas para os ensaios de marcação simples. As revelações foram realizadas adicionando-se o cromógeno do kit "Liquid Permanent Red" (Dako) por cerca de 1-3 minutos. Para interromper a reação, os tecidos foram lavados em água corrente por 10 minutos. Os tecidos foram contracorados e as lâminas montadas. As marcações desta reação são vistas ao microscópio na cor rosa/vermelha.

Em todos os ensaios de imunohistoquímica foram realizados os controles positivo e negativo das reações. O controle positivo é importante para observar a reprodutibilidade das reações - como a presença de marcação ou o número de células positivas -, e se baseia no uso de cortes histológicos, de tecidos tímicos com resultados previamente conhecidos, em ensaios subsequentes com cada anticorpo primário. O controle negativo é necessário para confirmar que a reação observada não é inespecífica, e consiste em completar todos os passos do protocolo de imunohistoquímica, exceto a etapa de incubação com o anticorpo primário. 


\subsubsection{Contagem celular e análises estatísticas}

As contagens de células $\mathrm{AlRE}^{+}$e $\mathrm{Foxp}^{+}$foram feitas ao microscópio, em aumento de 400 vezes, com o auxilio de um gratículo com dimensões conhecidas $\left(0,0625 \mathrm{~mm}^{2}\right)$, permitindo o cálculo das células de interesse por $\mathrm{mm}^{2}$ de medula tímica. Os padrões de contagem foram definidos em 9 campos por corte, sendo somente nas regiões de medula. As contagens seguem movimentos padronizados para todas as amostras, ou seja, a parte superior esquerda de uma região medular é focalizada e a contagem é feita em 3 campo da esquerda para a direita - se a região medular acabar antes de se completar a contagem dos 3 campos, foram feitos movimentos para a contagem do campo abaixo. Este procedimento é repetido em 5 regiões medulares diferentes de cada tecido, até ter contado 9 campos medulares.

As análises estatística foram feitas através do teste t não pareado (MannWhitney $U$ test) e correlação de Pearson ( $r$ ), com o auxílio do programa de computador "GraphPad Prism 5.0" (GraphPad Software, San Diego, CA, USA).

\subsubsection{Espécimes de timo e anticorpos utilizados}

$\mathrm{Na}$ tabela 1 estão apresentados os anticorpos primários utilizados para a marcação de AIRE e Foxp3 no timo humano. Para este estudo, foram utilizados 46 espécimes de timo provenientes de crianças submetidos à cirurgia cardíaca. Dados gerais sobre os pacientes doadores dos timos, como idade, sexo e tipo de cardiopatia, estão descritos na tabela 2.

Tabela 1 - Apresentação dos anticorpos primários utilizados para o estudo de AIRE e Foxp3 no timo humano.

\begin{tabular}{lcccc}
\hline \hline ANTICORPO PRIMÁRIO & HOSPEDEIRO & CONCENTRAÇÃO & FABRICANTE & CÉLULAS ALVO \\
\hline AIRE-1 $(\mathrm{H}-300)$ & coelho $(\mathrm{lgG})$ & $1,0 \mu \mathrm{g} / \mathrm{mL}$ & Santa Cruz Biotech & Em estudo \\
\hline Foxp3 $(14-4776-82)$ & rato $(\mathrm{lgG})$ & $1,0 \mu \mathrm{g} / \mathrm{mL}$ & EBioscience & Treg \\
\hline Pan-cytokeratin $(34 \beta E 12)$ & camundongo $(\mathrm{lgG})$ & $1,0 \mu \mathrm{g} / \mathrm{mL}$ & Dako & Epiteliais \\
\hline S-100 & coelho $(\mathrm{lgG})$ & $2,0 \mu \mathrm{g} / \mathrm{mL}$ & Dako & Dendríticas \\
\hline CD68 & camundongo $(\mathrm{lgG})$ & $4,0 \mu \mathrm{g} / \mathrm{mL}$ & Dako & Macrófagos \\
\hline
\end{tabular}




\subsection{Resultados}

\subsubsection{Coloração dos timos pelo método de HE}

Todos os timos foram corados pelo método de HE e observados ao microscópio em diferentes aumentos. Como exemplificado na figura 1, os timos estudados apresentaram as características morfológicas microscópicas típicas. Os tecidos continham as regiões cortical e medular bem definidas, claramente identificáveis pela marcante diferença de densidade celular e pela presença dos corpúsculos de Hassall exclusivamente na região medular. Foram observados septos, capsula e espaço perivascular. Em maiores aumentos, o endotélio das vênulas pós-capilares, através das quais as células progenitoras hematopoiéticas chegam ao timo, puderam ser claramente visualizadas na região córtico-medular.

2.3.2 Imunohistoquímica para identificação e análise da distribuição de células intratímicas

Foram realizados ensaios de imunohistoquímica com a finalidade de avaliar 0 padrão de distribuição de alguns tipos celulares intratímicos, como células epiteliais, dendríticas, macrófagos e timócitos $\mathrm{CD}^{+}$, em sete timos de pacientes com idades diferentes, selecionados aleatoriamente. Como exemplificado na figura 4, os resultados mostraram as células epiteliais citoqueratina ${ }^{+}$cercando a região subcapsular e subseptal, compondo os corpúsculos de Hassall e distribuídas nas regiões medular e cortical (Figuras 4A e B). As células dendríticas $5100^{+}$ apareceram marcadas, predominantemente, na região medular (Figura 4C), algumas no córtex (Figura 4D) e outras inseridas entre as células epiteliais dos corpúsculos de Hassall. Numerosos macrófagos $\mathrm{CD} 8^{+}$foram encontrados no córtex tímico, na região córtico-medular e menos numerosas na medula (Figuras 4E e F), e alguns na região medular e septos. Timócitos $\mathrm{CD}^{+}$foram observados em abundância em todas as regiões intratímicas (Figuras 4G e H). 

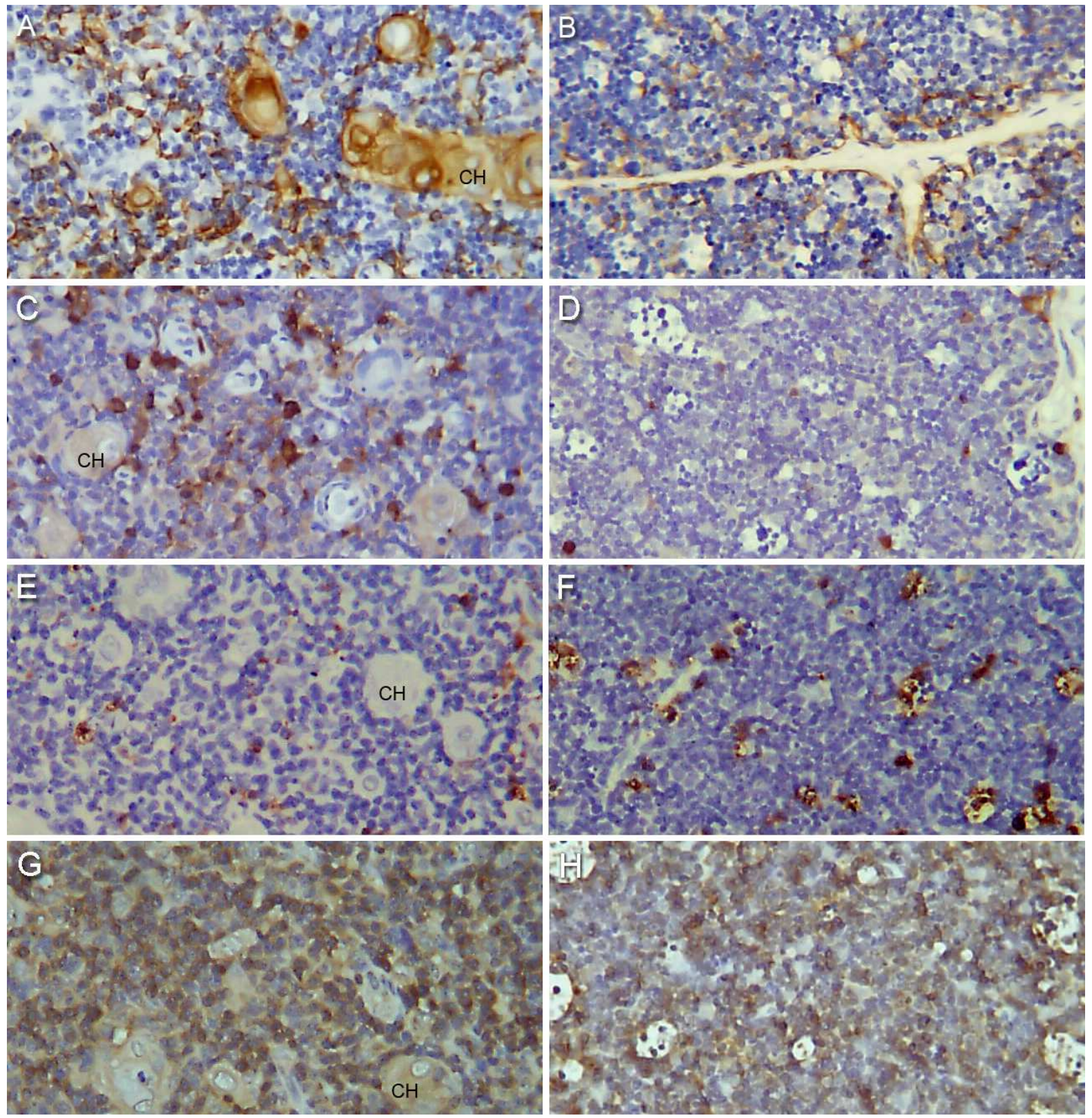

Figura 4. Imunomarcação de diferentes tipos celulares intratímicos. Pode-se observar marcação de: citoqueratina nas células epiteliais da medula $(\mathbf{A})$ e do córtex (B); S100 nas células dendríticas medulares (C) e corticais (D); CD68 em macrófagos da medula (E) e do córtex (F); e CD3 em timócitos localizados na medula $(\mathbf{G})$ e no córtex $(\mathbf{H})$ tímico. Corpúsculo de Hassall $(\mathrm{CH})$. Timo do paciente 3587983. Contracoloração por hematoxilina (núcleos azuis). Aumentos de 200x. 


\subsubsection{Imunohistoquímica para detecção de AIRE e Foxp3 no timo humano}

Ensaios de imunohistoquímica de fluorescência foram realizados com o intuito de analisar o padrão de expressão de AIRE no timo humano. Ao microscópio pudemos observar algumas células, localizadas na região medular, apresentando o núcleo fortemente marcado com anti-AIRE (Figura 5) e presença dos típicos dots nucleares (detalhe da Figura 5).

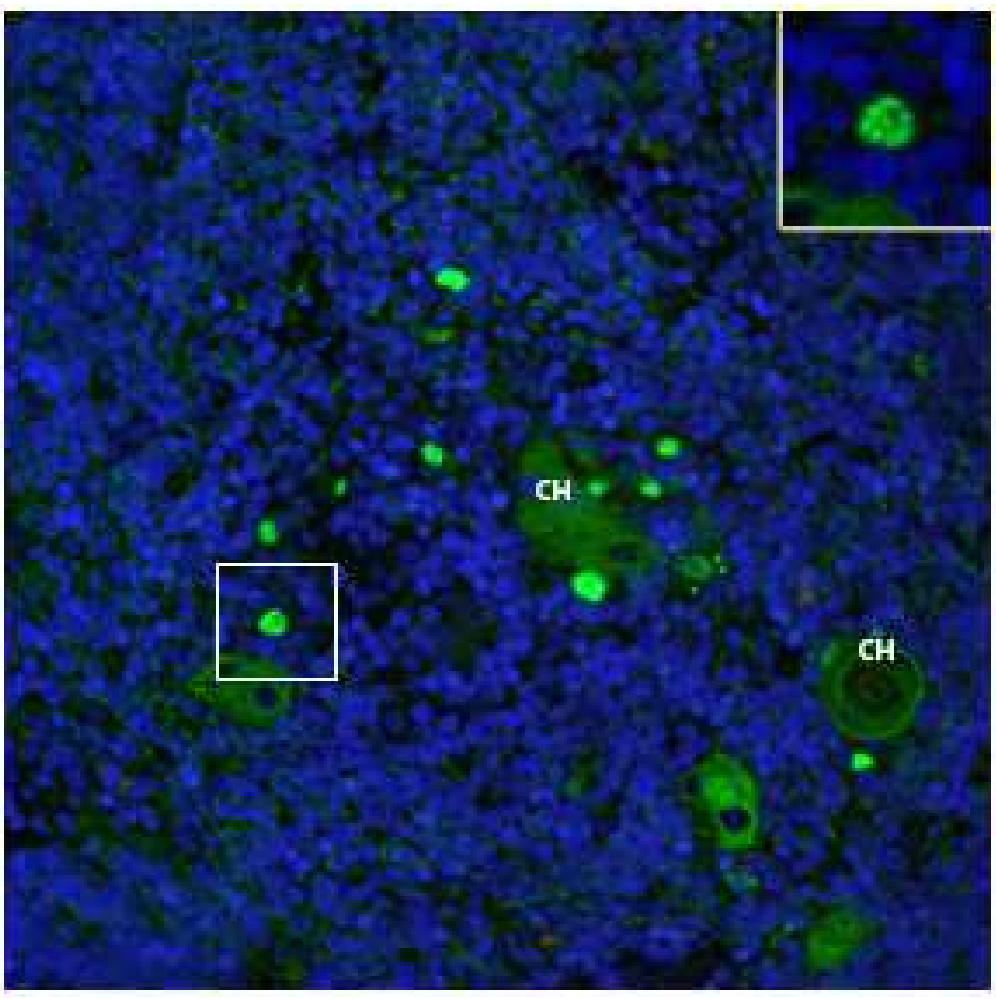

Figura 5. Imunofluorescência de AIRE na região medular do timo. Pode-se observar o padrão normal de expressão de AIRE, caracterizado pela presença de algumas CET com núcleos intensamente marcados (verde). Em azul, núcleos marcados com DAPI. Corpúsculo de Hassall (HC). Timo da paciente 3032434. Aumentos de 200x e 400x no detalhe. 
Para identificar o tipo celular capaz de expressar AIRE na medula tímica, ensaios de imunohistoquímica para dupla marcação cromogênica foram realizados utilizando-se os pares de anticorpos primários: anti-AIRE com anti-pancitoqueratina; e anti-AIRE com anti-S100. Os resultados revelaram que apenas algumas células epiteliais da medula tímica são $\mathrm{AIRE}^{+}$, enquanto nenhuma CET cortical foi encontrada expressando AIRE (Figura 6A e B). Células dendríticas S100+ não apresentaram marcação por anti-AIRE (dado não mostrado).
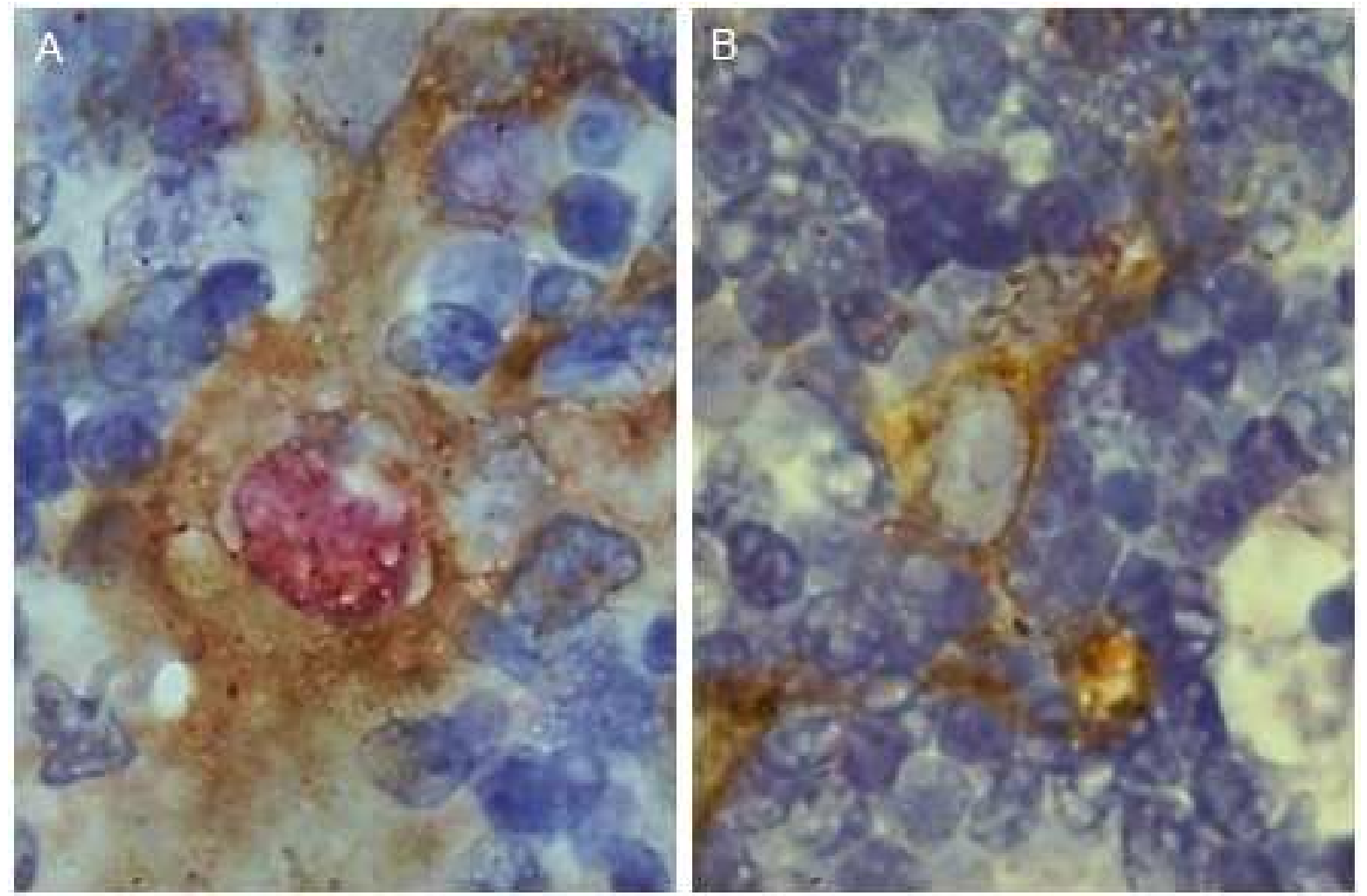

Figura 6. Ensaio de dupla marcação com os anticorpos primários anti-AIRE e anti-pancitoqueratina. Em A. podemos observar uma CET da região medular expressando AIRE (núcleo rosa) e citoqueratina (castanho); e em B. vemos uma CET cortical positiva apenas para citoqueratina (castanho). Timo do paciente 2995727. Contracoloração por hematoxilina. Aumento 1000x. 
A maioria das células epiteliais que compõe os corpúsculos de Hassall apresenta leve marcação de AIRE no citoplasma, como exemplificado na figura 7. Frequentemente, algumas típicas CET expressando AIRE nuclear são encontradas integradas aos corpúsculos de Hassall (Figura 7).

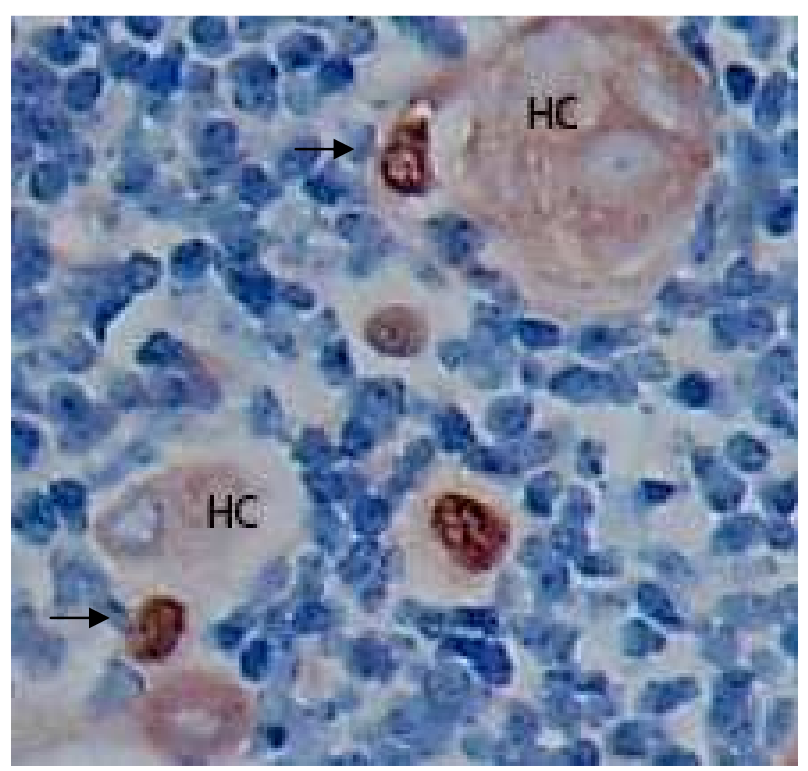

Figura 7. Imunohistoquímica para detecção de AIRE no timo humano. Podemos observar corpúsculos de Hassall (HC) discretamente marcado com anti-AIRE, bem como, algumas CET AIRE' fortemente marcadas na região medular, próximas e integradas (setas) aos corpúsculos de Hassall. Timo da paciente 2995727. Contracoloração por hematoxilina. Aumentos de 400x. 
$\mathrm{Na}$ região medular, em volta dos corpúsculos de Hassall, também estão distribuídos numerosos timócitos expressando Foxp3, ou seja, as células Treg naturais recém diferenciadas no timo humano (Figura 8).

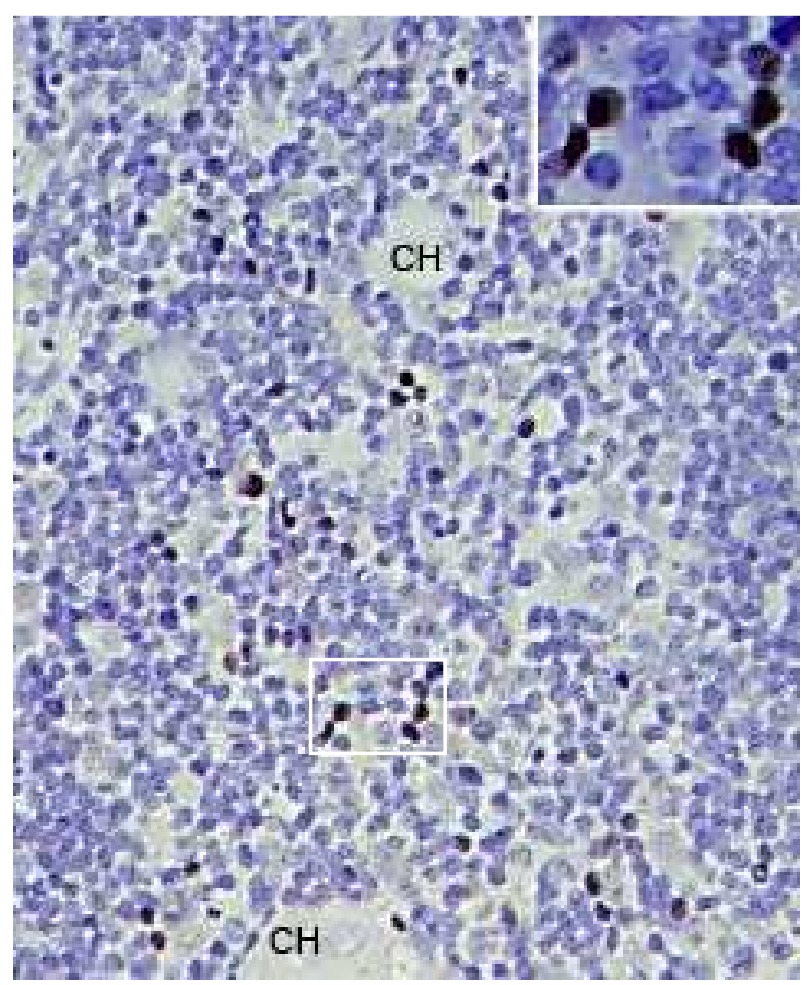

Figura 8. Imunohistoquímica para detecção de Foxp3 em timo humano. Podemos observar células Treg naturais com 0 núcleo fortemente marcado com anti-Foxp3. Corpúsculos de Hassall (CH). Timo da paciente 3032434. Contracoloração por hematoxilina. Aumentos de 200x e 400x no detalhe. 
2.3.4 Contagens de células $\mathrm{AIRE}^{+}$e Foxp3 ${ }^{+}$por $\mathrm{mm}^{2}$ de medula tímica e análises estatísticas dos dados

Com a finalidade de estudar o número de células epiteliais $\mathrm{AIRE}^{+}$e timócitos Foxp3 $3^{+}$por $\mathrm{mm}^{2}$ de medula tímica, cortes histológicos de 46 timos humanos foram marcados com os anticorpos anti-AIRE e anti-Foxp3, respectivamente, e tiveram as células positivas contadas ao microscópio, com o auxílio de um gratículo. Na tabela 2 estão apresentados os resultados do total de células expressando AIRE e Foxp3 por $\mathrm{mm}^{2}$, baseados na média das contagens de 9 campos medulares (Tabelas dos ANEXOS B.1 e B.2) de cada timo estudado.

Tabela 2 - Dados dos pacientes doadores dos timos e resultados das contagens de células $\mathrm{AIRE}^{+}$e Foxp3 ${ }^{+}$na medula tímica. (continua)

\begin{tabular}{|c|c|c|c|c|c|}
\hline REGISTRO & IDADE (DIAS) & SEXO & CARDIOPATIA & AIRE $^{+} / \mathrm{mm}^{2}$ & $\mathrm{FOXP3}^{+} / \mathrm{mm}^{2}$ \\
\hline 3575012 & 1 & - & SCEH & 74,67 & 643,56 \\
\hline 4199189 & 4 & $M$ & CVAD & 119,11 & 826,67 \\
\hline 3932834 & 5 & - & CVAD & 176,00 & 773,33 \\
\hline 3233154 & 6 & $M$ & CIV & 129,78 & 807,11 \\
\hline 3252060 & 7 & $M$ & $\mathrm{CIA}$ & 195,56 & 593,78 \\
\hline 3888010 & 13 & $\mathrm{~F}$ & MFCGA/CIA & 144,00 & 807,11 \\
\hline 3178781 & 16 & $\mathrm{~F}$ & MFCGA & 110,22 & 773,33 \\
\hline 3331792 & 18 & $\mathrm{~F}$ & SCEH & 167,11 & 464,00 \\
\hline 3790169 & 50 & M & SCEH & 48,00 & 232,89 \\
\hline 4427181 & 78 & $M$ & - & 179,56 & 1027,56 \\
\hline 3182274 & 90 & $M$ & TF/CAV/VDDS & 229,33 & 728,89 \\
\hline 3587983 & 103 & $M$ & VDDS & 243,56 & 423,11 \\
\hline 4446518 & 118 & $M$ & - & 241,78 & 922,67 \\
\hline 4664965 & 122 & $\mathrm{~F}$ & - & 218,67 & 720,00 \\
\hline 4565118 & 127 & $M$ & - & 122,67 & 1399,11 \\
\hline 4263685 & 132 & M & TF & 110,22 & 1006,22 \\
\hline 3225755 & 147 & $\mathrm{~F}$ & CAV & 172,44 & 924,44 \\
\hline 3012050 & 151 & $\mathrm{~F}$ & $\mathrm{CIA}$ & 165,33 & 1072,00 \\
\hline 2843757 & 192 & $M$ & AVP & 236,44 & 407,11 \\
\hline 3013014 & 207 & $M$ & CIV & 104,89 & 570,67 \\
\hline 2794640 & 221 & $\mathrm{~F}$ & AVP & 55,11 & 675,56 \\
\hline 3162877 & 225 & $M$ & CIV & 115,56 & 716,44 \\
\hline
\end{tabular}


Tabela 2 - Dados dos pacientes doadores dos timos e resultados das contagens de células $\mathrm{AIRE}^{+}$e Foxp3 ${ }^{+}$na medula tímica.

(conclusão)

\begin{tabular}{|c|c|c|c|c|c|}
\hline REGISTRO & IDADE (DIAS) & SEXO & CARDIOPATIA & $\operatorname{AlRE}^{+} / \mathrm{mm}^{2}$ & $\mathrm{FOXP3}^{+} / \mathrm{mm}^{2}$ \\
\hline 3233855 & 235 & $\mathrm{~F}$ & MFVC & 295,11 & 1111,11 \\
\hline 2995727 & 240 & $\mathrm{~F}$ & CIV & 236,44 & 519,11 \\
\hline 3794083 & 240 & $\mathrm{~F}$ & CIV & 216,89 & 768,00 \\
\hline 4592913 & 244 & $\mathrm{~F}$ & - & 209,78 & 753,78 \\
\hline 4200764 & 268 & $\mathrm{~F}$ & CIV & 119,11 & 620,44 \\
\hline 4059395 & 323 & $\mathrm{~F}$ & CAV & 103,11 & 686,22 \\
\hline 3032434 & 327 & $\mathrm{~F}$ & CIV & 256,00 & 632,89 \\
\hline 3971031 & 330 & M & VEDS & 74,67 & 775,11 \\
\hline 3776549 & 392 & $\mathrm{~F}$ & $\mathrm{CIA}$ & 92,44 & 293,33 \\
\hline 3223990 & 425 & $M$ & AVP & 112,00 & 661,33 \\
\hline 3790452 & 458 & $\mathrm{~F}$ & $\mathrm{CIA}$ & 133,33 & 1173,33 \\
\hline 4200748 & 725 & $M$ & ECVA & 186,67 & 666,67 \\
\hline 3027643 & 1571 & $M$ & $\mathrm{D} / \mathrm{L} / \mathrm{CT}$ & 172,44 & 563,56 \\
\hline 3393534 & 1800 & $\mathrm{~F}$ & CAV & 181,33 & 316,44 \\
\hline 3975940 & 1657 & $\mathrm{~F}$ & TF & 120,89 & 730,67 \\
\hline 3009793 & 1713 & $\mathrm{~F}$ & TF & 149,33 & 755,56 \\
\hline 3082849 & 1855 & $M$ & CIA & 199,11 & 728,89 \\
\hline 3213056 & 1961 & $M$ & CIV & 140,44 & 718,22 \\
\hline 2821826 & 2088 & $\mathrm{~F}$ & CIA & 129,78 & 506,67 \\
\hline 3177858 & 2285 & $\mathrm{~F}$ & $A A$ & 126,22 & 707,56 \\
\hline 2851008 & 2753 & $\mathrm{~F}$ & $\mathrm{CIA}$ & 163,56 & 602,67 \\
\hline 3175472 & 2911 & $M$ & CIA & 124,44 & 663,11 \\
\hline 4510135 & 3589 & $M$ & - & 309,33 & 1008,00 \\
\hline 752240 & 4045 & M & AVP & 104,89 & 599,11 \\
\hline
\end{tabular}

AA - Aneurisma de aorta

AVP - Atresia de valva pulmonar

CAV - Comunicação atrioventricular

CIA - Comunicação interatrial

CIV - Comunicação interventricular

CT - Cor triatriatrum

CVAD - Comunicação ventrículo-átrio discordante

D - Dextrocardia

ECVA - Estenose congênita de valva aórtica $L-$ Levocardia

MFCGA - Má formações congênitas das grandes artérias MFVC - Má formação dos vasos coronários SCEH - Síndrome do coração esquerdo hipoplásico TF - Tetralogia de Fallot/Comunicação aortopulmonar VDDS - Ventrículo direito com dupla via de saída

Os dados obtidos a partir das contagens de células $\mathrm{AIRE}^{+}$e Foxp3 ${ }^{+}$foram submetidos a análises estatísticas para verificar a média e a dispersão do grupo. 
A figura 9 apresenta a média e a dispersão, do número de células expressando AIRE (Figura 9A) e Foxp3 (Figura 9B), do grupo de 46 timos. O coeficiente de variação de AIRE e Foxp3 é de aproximadamente $38 \%$ e $32 \%$, respectivamente.

A

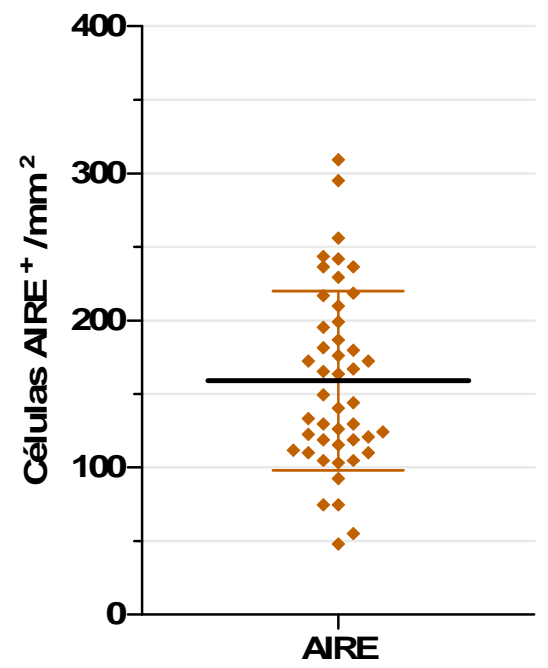

B

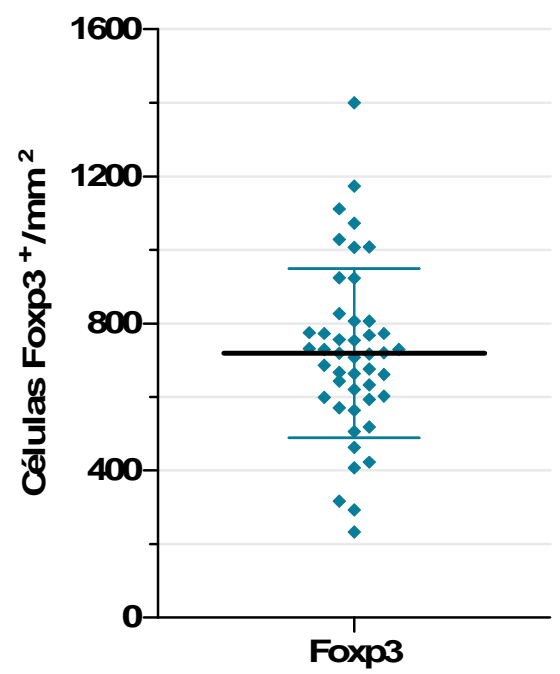

Figura 9. Média e desvio padrão do $n^{\circ}$ de células expressando (A) AIRE $(159,1 \pm 60,96$; $\mathrm{CV}=38 \%)$ e (B) Foxp3 (719,1 $\pm 229,60 ; \mathrm{CV}=32 \%)$ em 46 timos humanos. Coeficiente de variação (CV).

Análise estatística das diferenças de expressão das proteínas AIRE e Foxp3 entre faixas etárias e sexos diferentes

Para investigar possíveis relações entre a expressão de AIRE, bom como de Foxp3, e a idade ou sexo dos pacientes, os dados foram separados por faixa etária (inferior e superior a 1 ano de vida) e sexo, e analisados estatisticamente pelo teste Mann-Whitney. Os resultados mostraram que não há diferenças significantes quanto à expressão de AIRE e de Foxp3 entre lactentes menores de 1 ano e crianças com idade superior a 1 ano de vida (Figura 10), bem como entre os sexos feminino e masculino (Figura 11). 
A

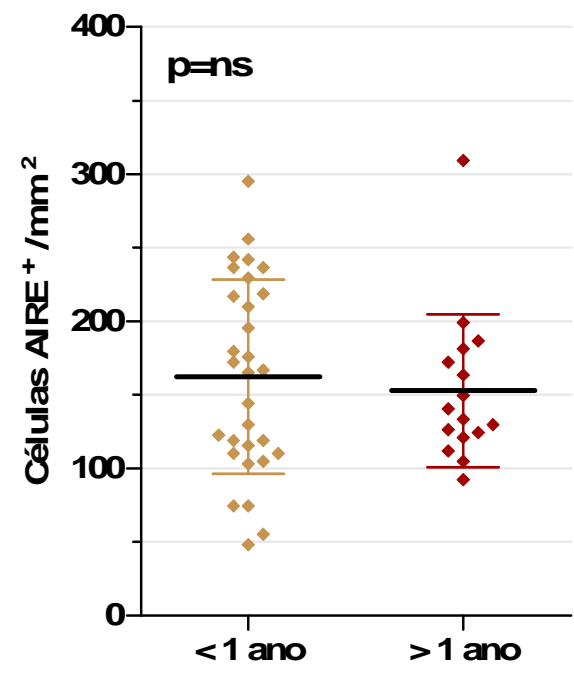

FAIXAETÁPA
B

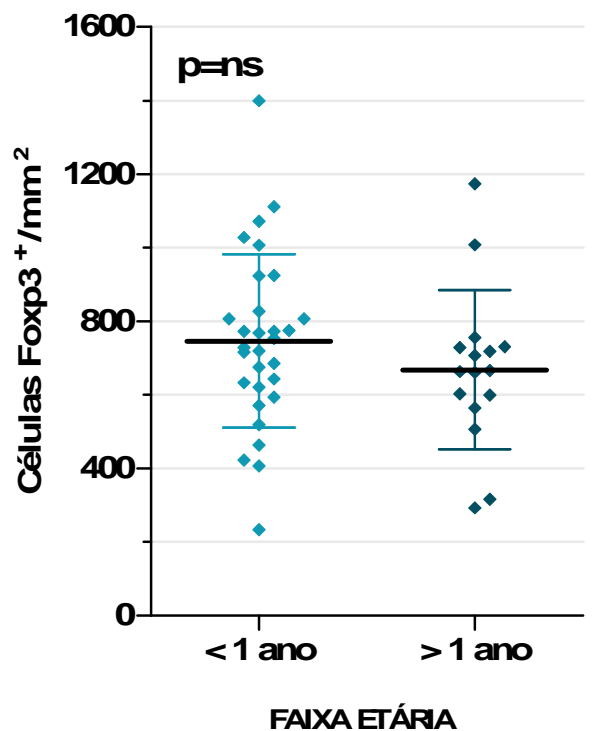

Figura 10. Análises através do teste estatístico de Mann-Whitney mostrando não haver diferenças significantes $(p=n s)$ entre $(\mathbf{A})$ a expressão de AIRE e $(\mathbf{B})$ de Foxp3 e a faixa etária dos pacientes menores $(n=30)$ e maiores $(n=16)$ de um ano de vida.

A

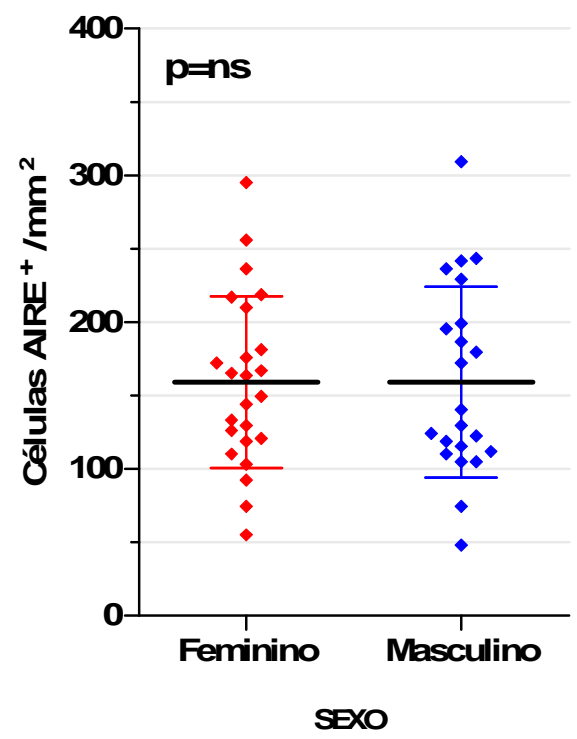

B

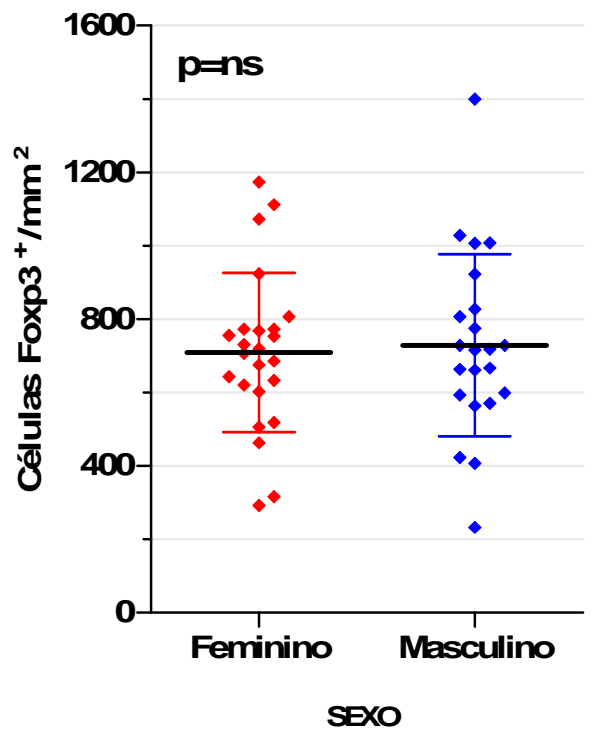

Figura 11. Teste de Mann-Whitney mostrando não haver diferenças significantes entre $(\mathbf{A})$ a expressão de AIRE ou (B) de Foxp3 e o sexo dos pacientes (feminino $n=24$ e masculino $n=22)$. 
Análises de correlação entre a expressão das proteínas AIRE e Foxp3 e a idade dos pacientes

O teste de correlação de Pearson foi utilizado para analisar possíveis relações entre expressão de AIRE e de Foxp3 e a idade dos pacientes estudados. Os resultados, apresentados na figura 12, mostram que não há correlação significante entre a idade do paciente e o número de células AIRE (Figura 12A) e Foxp3 (Figura 12B) positivas.

A

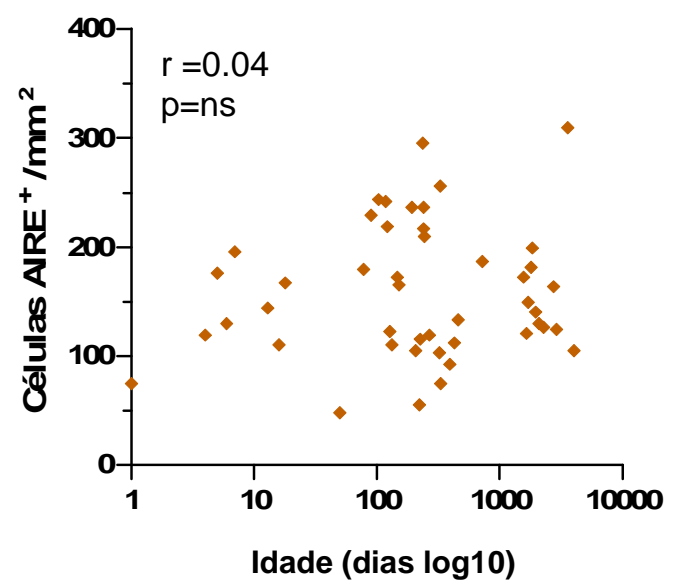

B

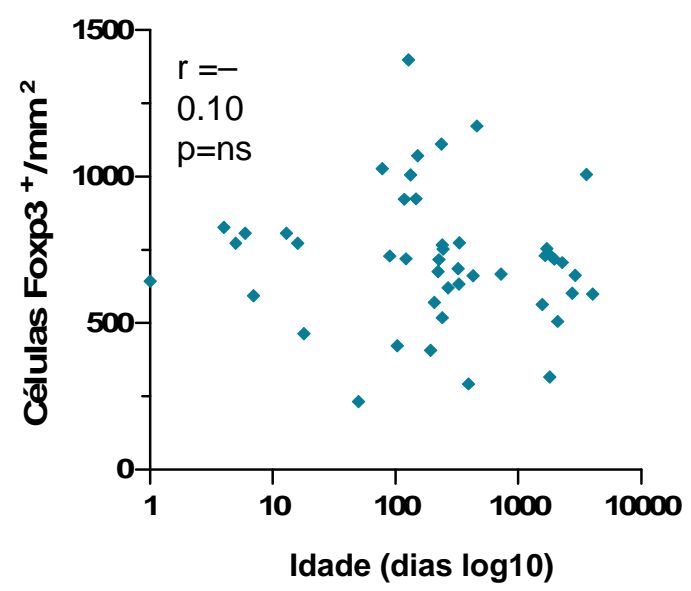

Figura 12. Correlação de Pearson mostrando não haver correlação significante entre a idade dos pacientes e a expressão de (A) AIRE $(r=0.04, p=n s)$ e de (B) Foxp3 $(r=0.10 ; p=n s)$.

\section{Análise de correlação entre a expressão AIRE e de Foxp3 no timo humano}

Para avaliar se há correlação entre o número de células $\mathrm{AIRE}^{+}$e a expressão de Foxp3, os dados foram analisados através do teste de correlação de Pearson. Os resultados mostraram não haver correlação significante entre a expressão destas proteínas (Figura 13). 


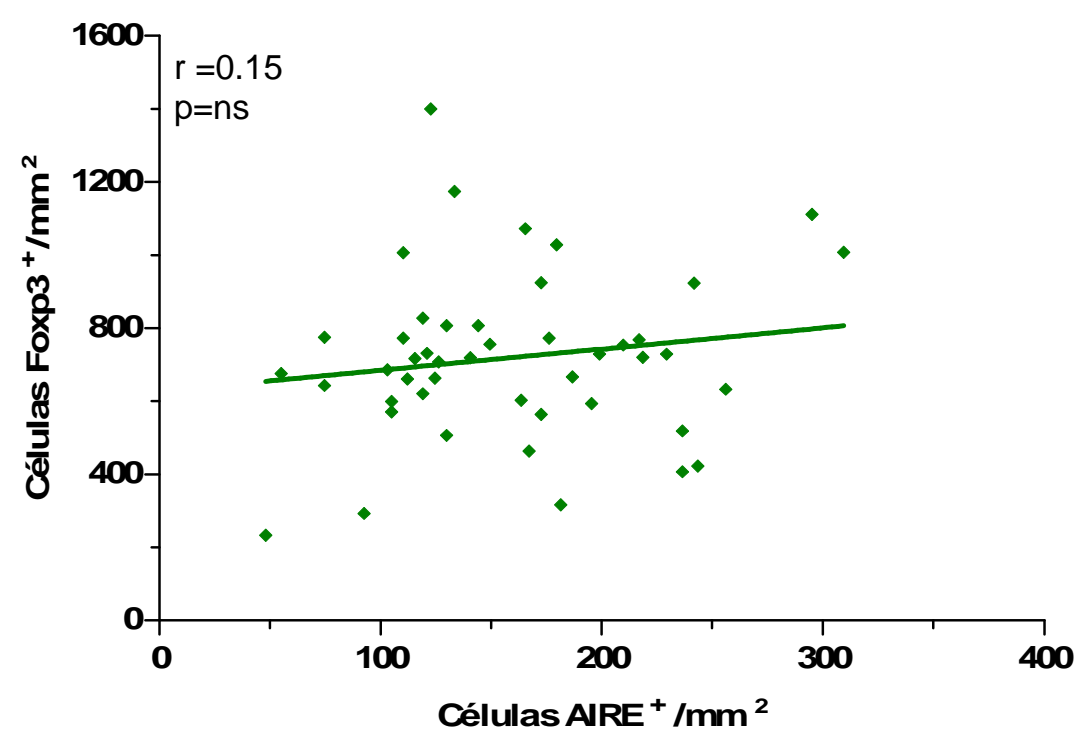

Figura 13. Análise estatística mostrando não haver correlação significante $(r=0.15 ; p=n s)$ entre $o n^{\circ}$ de células epiteliais AIRE ${ }^{+}$e o $n^{\circ}$ de timócitos Foxp3 ${ }^{+}$.

\subsection{Discussão}

Os timos selecionados para este estudo apresentaram características morfológicas consideradas normais (von Gaudecker, 1991; Shuurman et al., 1997; Hale, 2004), com nítida delimitação entre as regiões cortical e medula, presença de cápsula, septos, vasos, além da presença medular de estruturas típicas do timo, os corpúsculos de Hassall (Figura 1). Além disto, todos os timos apresentaram a distribuição celular intratímica bem característica, (von Gaudecker, 1991; Shuurman et al., 1997; Hale, 2004; Raica et al., 2006), com presença de células epiteliais, predominantemente, na medula, corpúsculos de Hassall, regiões subseptal e subcapsular (Figura 4A), e áreas na região cortical isentas de epitélio (Figura 4B) (von Gaudecker, 1991); as células dendríticas foram vistas em maior quantidade na região medular (Figuras 4C e D) e os macrófagos, na região cortical (Figuras 4E e F); timócitos $\mathrm{CD3}^{+}$foram observados em abundância no timo (Figuras 4G e H).

Células $\mathrm{AIRE}^{+}$foram encontradas na região medular dos 46 timos analisados. O padrão de expressão subcelular observado foi semelhante ao descrito pela 
primeira vez por Heino et al. (1999), ou seja, algumas células medulares contendo núcleos repletos de AIRE e apresentando pequenos dots nucleares fortemente marcados (Figura 5).

Após a descoberta de AIRE, houve várias controvérsias significantes sobre o a distribuição desta molécula em diferentes tecidos e tipos celulares. Alguns estudos demonstraram uma ampla distribuição de AIRE em muitos órgãos (Finnish-German APECED Consortium, 1997), enquanto outros apresentaram uma localização completamente restrita a órgãos linfoides, em particular no timo (Nagamine et al., 1997; Heino et al., 1999; Klamp et al., 2006). Certamente, esta discrepância pode refletir diferenças na especificidade dos reagentes e na sensibilidade das técnicas aplicadas. Em nosso estudo, a proteína AIRE foi encontrada apenas em algumas das células epiteliais medulares citoqueratina ${ }^{+}$(Figura 6A). As células epiteliais

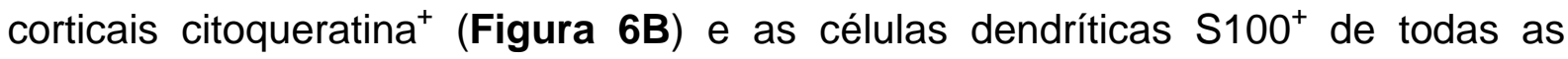
regiões tímicas, não apresentaram expressão de AIRE.

Apesar do padrão de expressão subcelular de AIRE ter se mostrado pouco variável entre todos os timos estudados, observamos um considerável coeficiente de variação (38\%) do número de células $\mathrm{AIRE}^{+}$por $\mathrm{mm}^{2}$ de medula tímica (Figura 9A). Embora exista esta variação moderada, não foram encontradas diferenças significantes do número de células expressando AIRE entre as faixas etárias (menores e maiores de 1 ano de vida) ou sexos dos pacientes (Figuras 10A e 11A). Também não foram encontradas correlações entre expressão de AIRE e a idade dos pacientes (Figura 12A). De fato, os nossos dados estão de acordo com os achados de Taubert et al. (2007), que demonstraram, através de análise quantitativa da expressão de mRNA, não haver correlação entre a idade e/ou o sexo do paciente doador do timo e o nível de expressão de AIRE.

Numerosos timócitos $\mathrm{Foxp}^{+}$foram encontrados na medula tímica dos 46 espécimes analisados (Figura 8). As contagens de células Foxp3 ${ }^{+}$por $\mathrm{mm}^{2}$ de medula mostraram certa variabilidade de expressão ( $C V=32 \%)$ entre indivíduos (Figura 9B). A expressão de Foxp3 não mostrou diferenças significantes entre faixas etárias (menores e maiores de 1 ano de idade) ou sexo dos pacientes (Figuras 10B e 11B). Nenhuma correlação foi evidenciada entre a expressão de Foxp3 e a idade dos pacientes (Figura 12B). 
A maioria das células epiteliais que compõem os corpúsculos tímicos apresenta leve marcação de AIRE no citoplasma, e algumas expressam o típico AIRE nuclear (Figura 7). Estas observações podem sugerir uma possível aproximação e integração das células $\mathrm{AlRE}^{+}$medulares aos corpúsculos, com subsequente perda das funções relacionadas diretamente à regulação da transcrição de genes importantes para o sucesso da seleção negativa.

Apesar das fortes evidências sobre a participação de AIRE na indução de células Treg (Kekalainen et al., 2007), a correlação entre AIRE e Foxp3 dos 46 timos testados não foi significante (Figura 13). 
CApítulo 3 


\section{ESTUDO DA EXPRESSÃO DAS PROTEÍNAS AIRE E FOXP3 EM TIMOS DE CRIANÇAS PORTADORES DA SÍNDROME DE DOWN}

\subsection{Introdução}

Pacientes com trissomia do cromossomo 21 manifestam a síndrome de Down (SD), que é a mais comum (1:1000 nascidos vivos) e a mais conhecida desordem genética. O fenótipo da SD é caracterizado por mais de 80 achados clínicos, incluindo retardo mental, hipotonia muscular, baixa estatura, dismorfismo facial, cardiopatia congênita, risco aumentado de desenvolver leucemia, alta suscetibilidade a infecções e manifestações autoimunes. Estes características clínicas são muito variáveis em número e intensidade.

O timo de portadores da SD apresenta uma proporção diminuída de timócitos, fenotipicamente maduros, expressando TCR $\alpha \beta$ e a molécula de CD3 associada, em comparação com timos de indivíduos sem a SD dentro da mesma faixa etária (Murphy et al., 1990); além disto, no sangue periférico, apresenta uma baixa proporção de linfócitos $T \alpha \beta$ (61\% versus $67 \%$, respectivamente) e uma aumentada proporção de linfócitos expressando TCR $\gamma \delta$ (12\% versus $7 \%$, respectivamente) (Murphy et al., 1990), bem como uma baixa porcentagem de células T naïve CD4 ${ }^{+}$

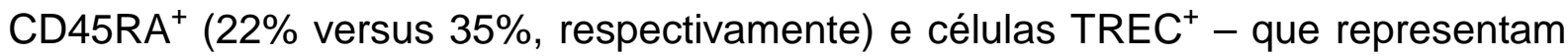
os linfócitos que recém-emigrados do timo -, além de uma alta porcentagem de células T de memória CD29+ (Murphy et al., 1990; Murphy et al., 1992a). Estes achados podem ser interpretados como um sinal de envelhecimento precoce do sistema imune na SD (Murphy et al., 1990; Barrena et al., 1993), uma vez que os linfócitos Th e citotóxicos naïve, bem como células $\mathrm{TREC}^{+}$na periferia, diminuem naturalmente com a idade, enquanto aumentam as células Th efetoras de memória e os linfócitos $T$ citotóxicos terminalmente diferenciados. A superexpressão das citocinas TNF- $\alpha$ (tumour necrosis factor) e interferon- $\gamma$, descrita por Murphy et al. (1992b), sugere uma desregulação tímica da produção destas moléculas, que pode 
ser uma explicação para a anatomia alterada do órgão (Larocca et al., 1990) e a maturação de timócitos prejudicada na SD.

Indivíduos com SD apresentam características autoimunes que se assemelham, em alguns aspectos, às que ocorrem em pacientes com a rara síndrome APECED, como manifestações de tireoidite autoimune (3-28\%), diabetes tipo 1 (1,4-10,6\%), doença celíaca, hipoparatiroidismo e hepatite autoimune crônica, entre outras (Chistiakov, 2007). Alguns estudos mostraram também uma alta prevalência de autoanticorpos contra múltiplos autoantígenos em crianças e adolescentes com SD (Murphy et al. 1995; Karlsson et al., 1998; Södrerbergh et al., 2006; Utiyama et al., 2008).

A localização cromossomal do gene AIRE e o grande espectro de doenças autoimunes manifestadas por pacientes com SD nos alertam para um possível desequilíbrio da expressão do gene AIRE na trissomia do cromossomo 21. Estes dados são interessantes do ponto de vista científico, pois podem auxiliar na compreensão do complexo cenário das manifestações autoimunes relacionados à expressividade de AIRE no timo, bem como a sua influência sobre a indução de células Foxp3 ${ }^{+}$.

Neste prisma, o ponto fundamental que deve ser analisado é o potencial de alterações de expressão do AIRE em indivíduos com defeitos no cromossomo 21 , comparando-se com indivíduos com cardiopatias como malformação isolada sem síndrome de Down. Os achados podem contribuir para a elucidação das relações diretas de AIRE no timo e prováveis consequências periféricas.

\subsubsection{Objetivos}

- Estudar, através de ensaios de imunohistoquímica, a expressão da proteína AIRE em timos provenientes de crianças com SD;

- Estudar a expressão da proteína Foxp3 em timos de pacientes com SD. 


\subsection{Material e métodos}

Timos provenientes de 15 crianças portadoras da síndrome de Down, submetidos a cirurgias cardíacas, foram utilizados para estudar a expressão AIRE e Foxp3. Dados gerais sobre os pacientes doadores dos timos, como idade, sexo e tipo de cardiopatia, estão descritos na tabela 3. O procedimento de coleta de timos, os ensaios de imunohistoquímica, o método de contagens de células positivas e as análises estatísticas foram realizados como descrito no Capítulo 2. Para as reações de marcação simples, foram utilizados os anticorpos primários anti-AIRE e antiFoxp3; e para as marcações duplas, além do anti-AIRE, os anticorpos primários anti-pan-citoqueratina e anti-S100.

\subsection{Resultados}

\subsubsection{Coloração dos timos de pacientes com SD pelo método de HE}

Os timos do grupo SD foram corados pelo método de HE e observados ao microscópio em diferentes aumentos. Como exemplificado na figura 14, a maioria dos espécimes estudados apresentou algumas características morfológicas semelhantes às observadas nos timos do grupo controle, como córtex e medula bem definidos, presença de corpúsculos de Hassall na medula, vasos, septos e cápsula, entretanto, com a celularidade tímica reduzida. Alguns timos apresentaram os corpúsculos de Hassall precocemente aumentados, associados ao estreitamento da região cortical. Dois dos timos estudados (3660729 e 4707745) apresentaram morfologia muito alterada, com pouca distinção entre as regiões medular e cortical, além de uma acentuada redução do número total de células intratímicas e poucos corpúsculos de Hassall. 


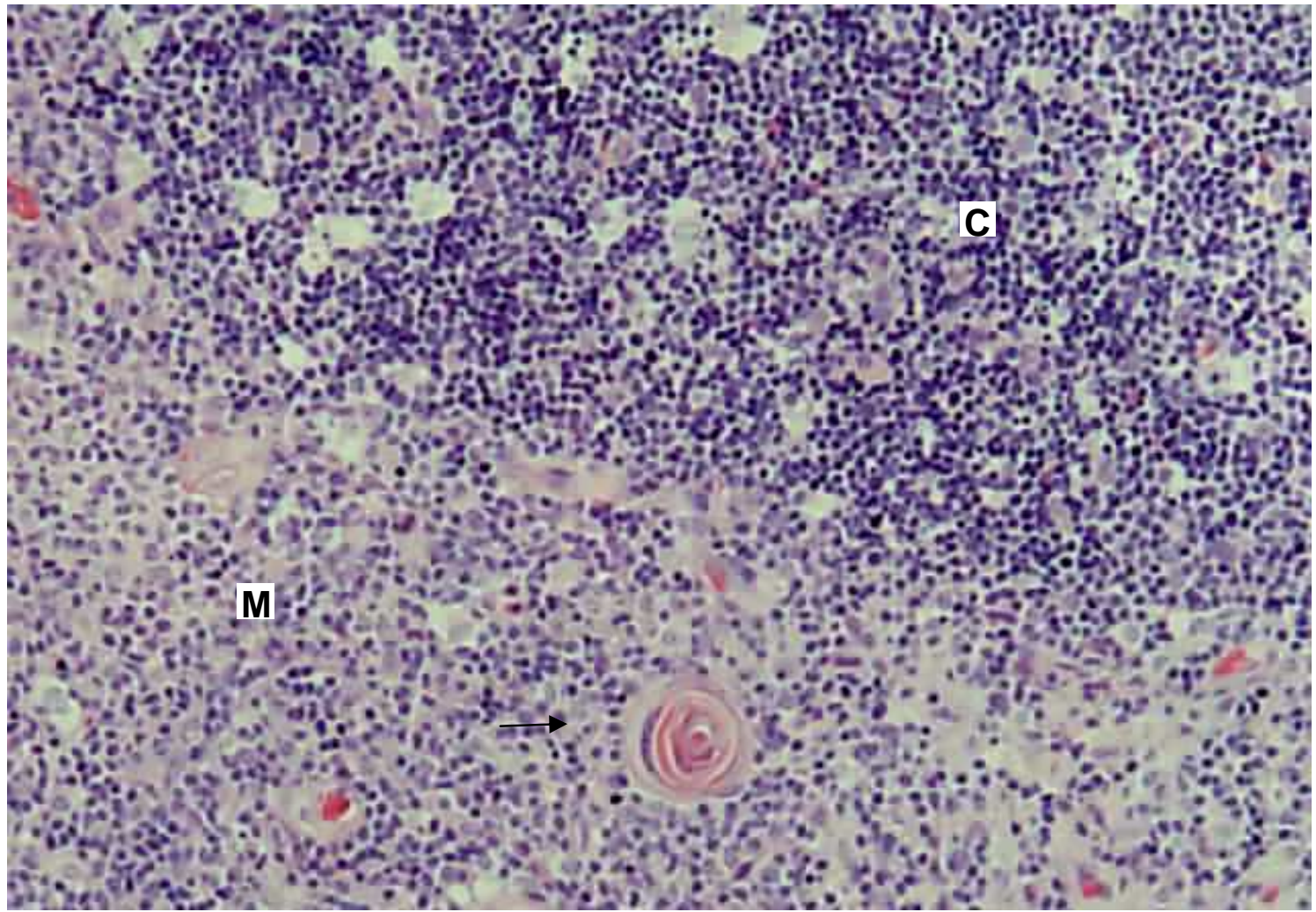

Figura 14. Corte histológico de lóbulo tímico do grupo SD. Corpúsculo de Hassall (seta). Córtex (C); medula (M). Corado pelo método de HE. Aumento de 40x.

3.3.2 Imunohistoquímica para identificação e análise da distribuição de células intratímicas do grupo SD

O padrão de distribuição de células epiteliais, dendríticas, macrófagos e timócitos $\mathrm{CD}^{+}$foi avaliado em três timos de pacientes com SD, selecionados aleatoriamente. Como exemplificado na figura 15, os timos apresentaram um padrão de marcação de células intratímica semelhante ao observado nos timos do grupo controle (Figura 4). 

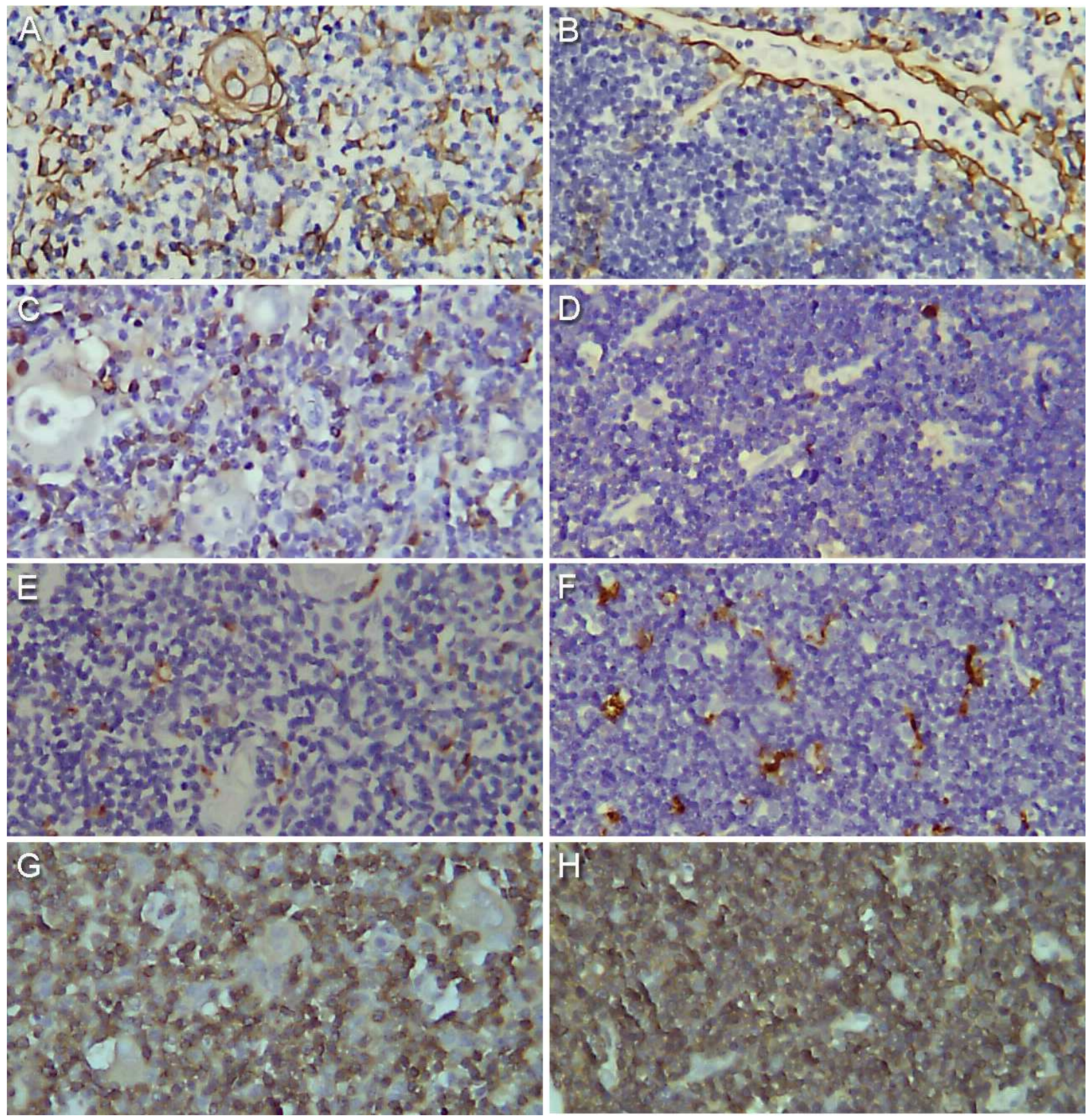

Figura 15. Imunomarcação de diferentes tipos celulares em timo do grupo SD. Pode-se observar marcação de: citoqueratina nas células epiteliais da medula $(\mathbf{A})$ e do córtex (B); S100 nas células dendríticas medulares (C) e corticais (D); CD68 em macrófagos da medula (E) e do córtex (F); e CD3 em timócitos localizados na medula $(\mathbf{G})$ e no córtex $(\mathbf{H})$ tímico. Corpúsculo de Hassall $(\mathrm{CH})$. Contracoloração por hematoxilina. Timo do paciente 4191404. Aumentos de 200x. 


\subsubsection{Imunohistoquímica para detecção de AIRE e Foxp3 em timos do grupo SD}

Ensaios de imunohistoquímica foram realizados com a finalidade de avaliar a expressão de AIRE em 15 timos provenientes de crianças com trissomia do cromossomo 21 (grupo SD). Os tecidos também foram avaliados quando à expressão de Foxp3. Os dados encontrados foram analisados e comparados com os resultados obtidos a partir dos 46 timos de pacientes sem a síndrome de Down (grupo controle), descritos no Capítulo 2.

Ao microscópio foram observadas células epiteliais medulares apresentando menor expressão de AIRE na maioria dos timos do grupo SD. Como exemplificado na figura 16, além da marcação de AIRE se mostrar mais tênue, sugerindo uma menor concentração desta proteína no núcleo, também há um número menor de células positivas na medula tímica, quando comparado com os timos do grupo controle.
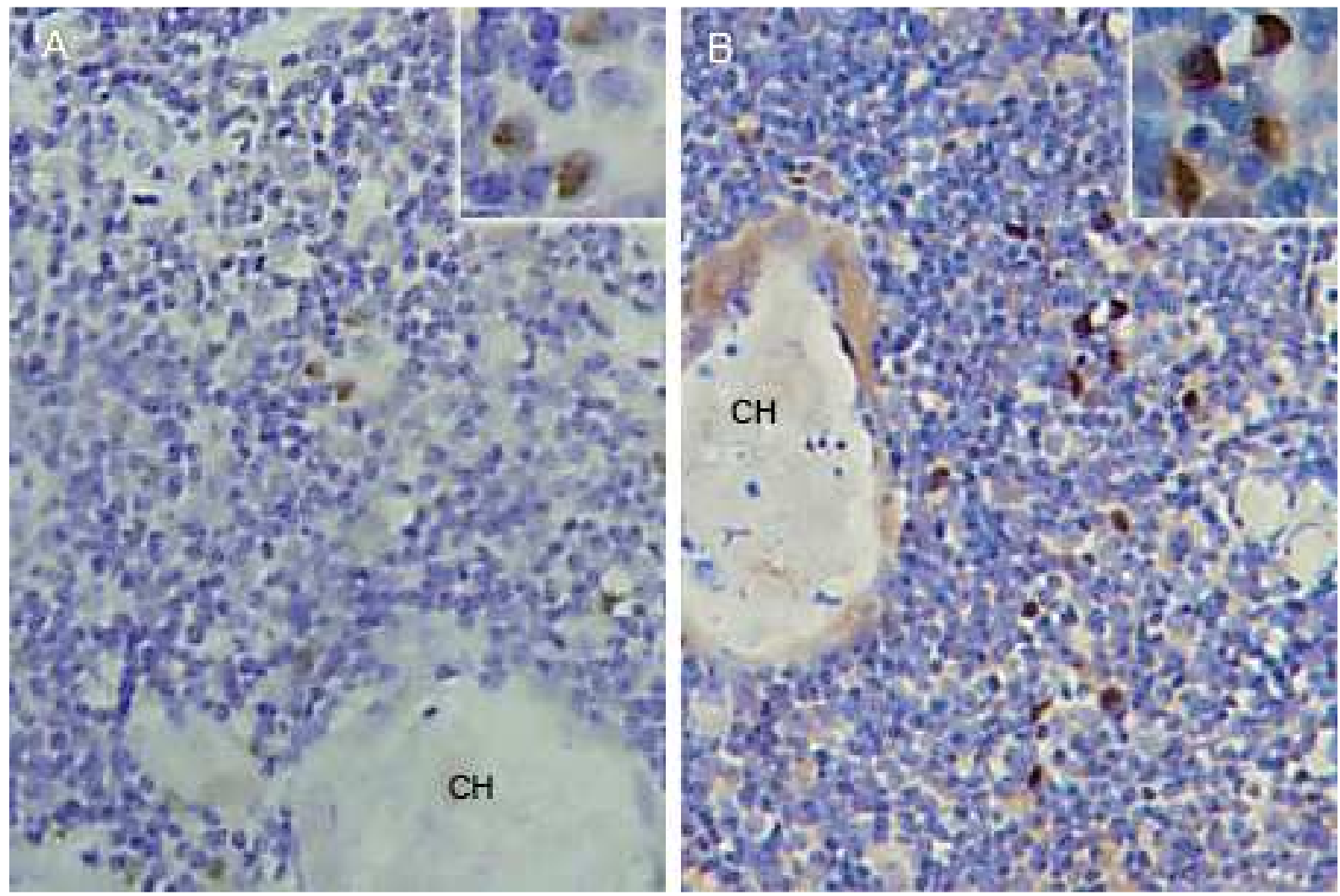

Figura 16. Imunohistoquímica para detecção de AIRE em timos de pacientes dos grupos (A) $\mathrm{SD}$ e (B) controle. Corpúsculos de Hassall $(\mathrm{CH})$. Timos das pacientes $3657361 \mathrm{e}$ 3032434, respectivamente. Contracoloração por hematoxilina. Aumentos de 200x e 400x no detalhe. 
Como pode ser observada na figura 17, a expressão de Foxp3 se mostrou semelhante àquela vista nos timos do grupo controle (Figura 8), ou seja, numerosos timócito Foxp3 ${ }^{+}$na região medular.

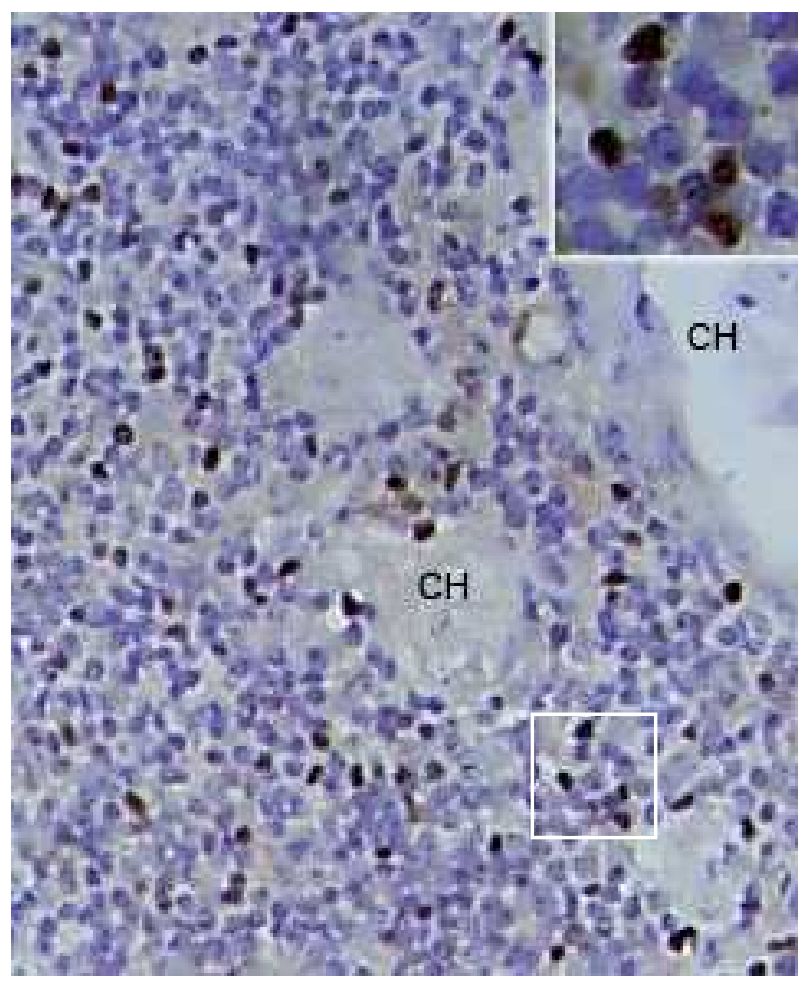

Figura 17. Imunohistoquímica para detecção de Foxp3 em timo de paciente do grupo SD. Podemos observar células Treg naturais, com o núcleo fortemente marcado com anti-Foxp3, por toda a região medular. Corpúsculos de Hassall $(\mathrm{CH})$. Timo do paciente 3314480. Contracoloração com hematoxilina. Aumentos de 200x e $400 x$ no detalhe.

3.3.4 Contagens de células AIRE ${ }^{+}$e Foxp3 $^{+}$nos timos do grupo $S D$ e análises estatísticas dos dados

Visando quantificar a expressão de AIRE e Foxp3 nos timos do grupo SD, foram realizadas contagens do número de células epiteliais $\mathrm{AIRE}^{+}$e de timócitos Foxp3 ${ }^{+}$por $\mathrm{mm}^{2}$ de medula tímica. Na tabela 3 estão apresentados os resultados do 
total de células expressando AIRE e Foxp3, baseados na média das contagens de 9 campos medulares (Tabelas dos ANEXOS B.3 e B.4) de cada timo estudado.

Assim como no grupo controle (Capítulo 2), os dados obtidos com as contagens de células positivas nos timos do grupo SD foram analisados estatisticamente para verificar: a média e a dispersão; diferenças de expressão entre grupos de faixas etárias e sexos distintos; a correlação entre o número de células positivas encontradas e a idade dos pacientes doadores dos timos; e a correlação entre as expressões de AIRE e Foxp3. Além disto, os dados do grupo SD foram comparados com os resultados encontrados nos timos do grupo controle.

Tabela 3 - Dados dos pacientes com síndrome de Down e resultados das contagens de células AIRE ${ }^{+}$e Foxp3 ${ }^{+}$por $\mathrm{mm}^{2}$ de medula tímica.

\begin{tabular}{cccccc}
\hline REGISTRO & IDADE (DIAS) & SEXO & CARDIOPATIA & AIRE $^{+} / \mathbf{m m}^{2}$ & FOXP3 $^{+} / \mathbf{m m}^{2}$ \\
\hline 3888690 & 140 & M & CIV & 28,44 & 471,11 \\
\hline 4191404 & 182 & M & TF & 96,00 & 1088,00 \\
\hline 4707745 & 204 & F & - & 5,33 & 320,00 \\
\hline 3660729 & 213 & F & CAV & 14,22 & 433,78 \\
\hline 3657361 & 326 & F & CIV & 40,89 & 592,00 \\
\hline 3161420 & 330 & F & TF & 24,89 & 407,11 \\
4078608 & 376 & F & TF/CAV & 94,22 & 1290,67 \\
\hline 3886379 & 418 & F & TF & 67,56 & 1125,33 \\
\hline 4564448 & 444 & M & - & 83,56 & 1425,78 \\
\hline 4423666 & 549 & F & - & 151,11 & 1153,78 \\
\hline 3710920 & 565 & F & CAV & 163,56 & 1708,44 \\
\hline 4018427 & 597 & F & - & 183,11 & 1059,56 \\
\hline 3324370 & 2474 & M & CIV & 60,44 & 220,44 \\
\hline 3314480 & 3752 & M & CAV & 117,33 & 812,44 \\
\hline 3461351 & 4753 & M & CIA & 39,11 & 204,44 \\
\hline
\end{tabular}

CAV - Comunicação atrioventricular

CIA - Comunicação interatrial

CIV - Comunicação interventricular

TF - Tetralogia de Fallot/Comunicação aortopulmonar 
A figura 18 mostra a dispersão dos dados obtidos com as contagens de células expressando AIRE (Figura 18A) e Foxp3 (Figura 18B), nos 15 timos estudados. O coeficiente de variação de AIRE e Foxp3 é de aproximadamente $72 \%$ e $58 \%$, respectivamente.

A

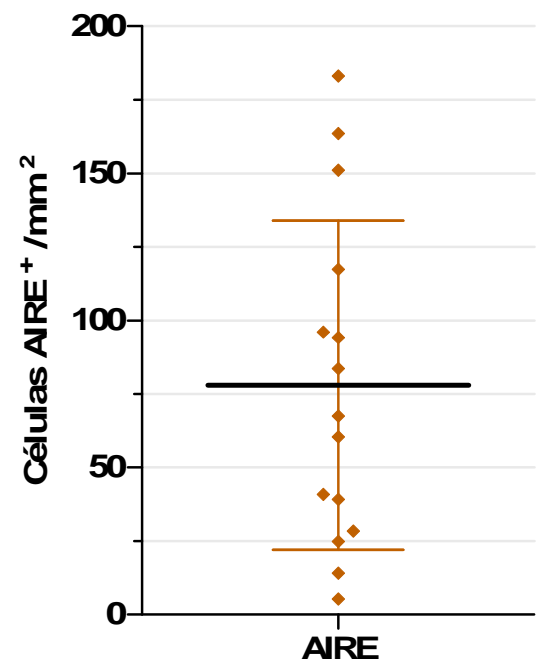

B

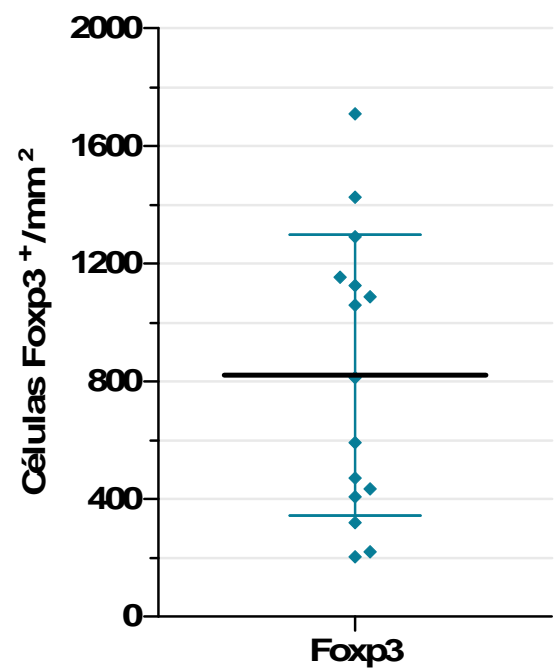

Figura 18. Média e desvio padrão do $n^{\circ}$ de células expressando (A) AIRE $(77,9 \pm 55,94$; CV=72\%) e (B) Foxp3 (820,9 $\pm 477,60$; CV=58\%) em 15 timos provenientes de crianças com síndrome de Down. Coeficiente de variação (CV). 
Análise estatística das diferenças de expressão das proteínas AIRE e Foxp3 entre faixas etárias e sexos diferentes

Para avaliar os níveis de expressão de AIRE e de Foxp3 em pacientes com idades e gêneros diferentes, os dados foram separados por faixa etária e sexo, e analisados estatisticamente pelo teste Mann-Whitney.

Os resultados mostraram que a expressão de AIRE está significativamente diminuída $(p<0.01)$ no grupo $S D$ com idade inferior a 1 ano (Figura 19A), em comparação com crianças maiores de 1 ano. Em relação à expressão de $\mathrm{Foxp}^{+}$, a diferença encontrada entre as faixas etárias não é estatisticamente significante (Figura 19B).

A

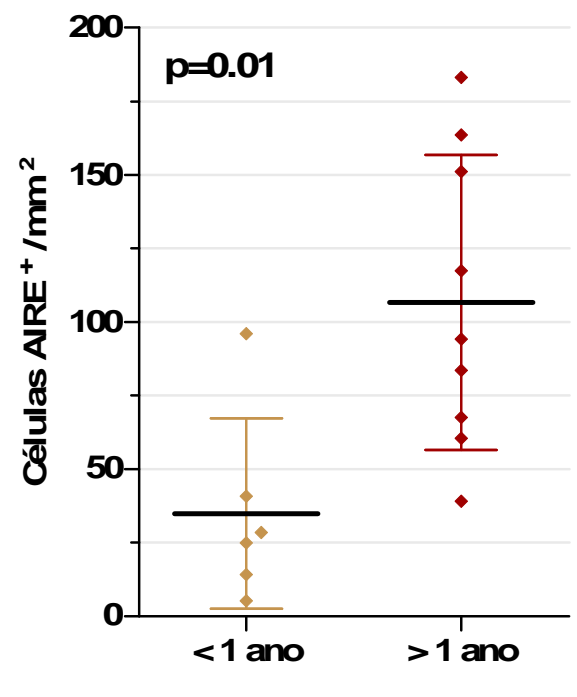

FAIXA ETÁRA
B

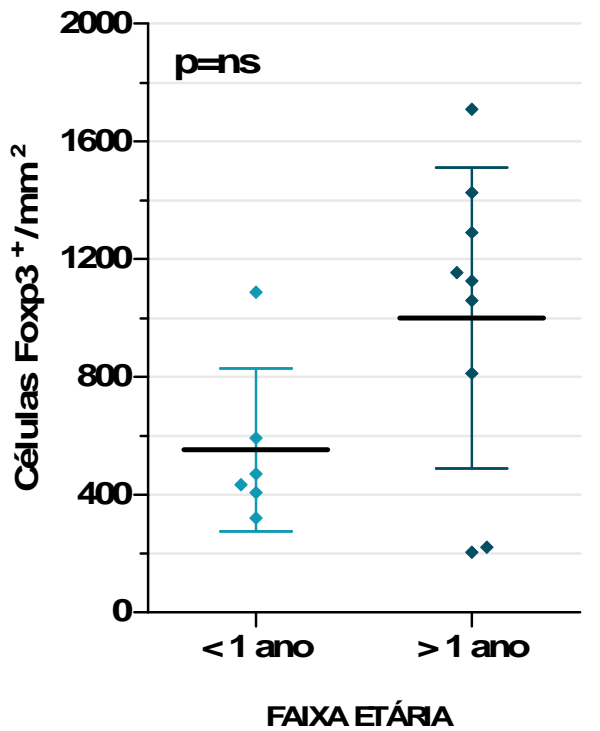

Figura 19. Análises através do teste estatístico de Mann-Whitney mostrando (A) uma diferença significante $(\mathrm{p}=0.01)$ de expressão de AIRE entre os pacientes menores $(n=6)$ e maiores $(n=9)$ de um ano de vida, enquanto (B) não houve diferença significante de expressão de Foxp3 entre as faixas etárias. 
Quando a expressão de AIRE e de Foxp3 foi avaliada em relação ao sexo dos pacientes, também não foram encontradas diferenças significantes entre o grupo feminino e o masculino (Figura 20).

A

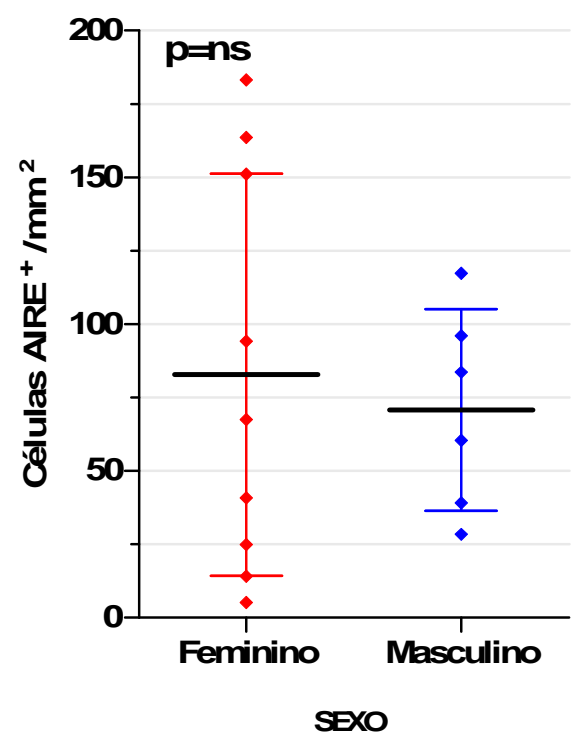

B

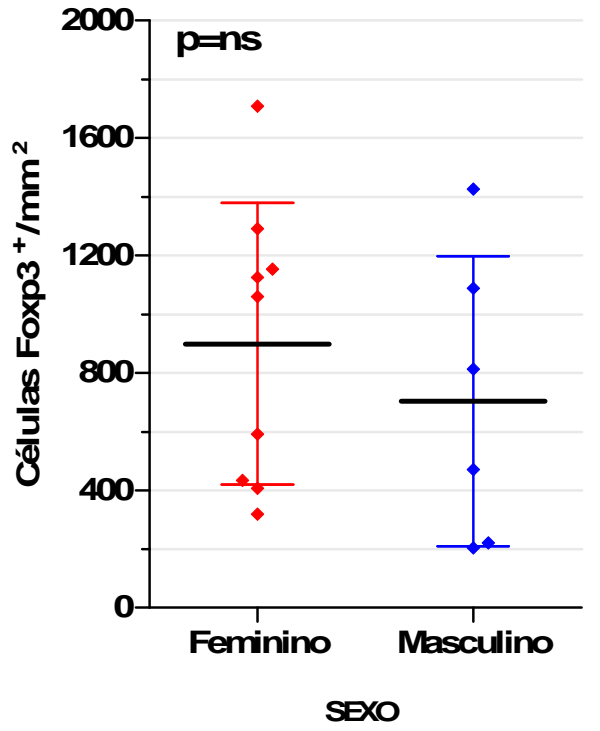

Figura 20. Teste de Mann-Whitney mostrando não haver diferenças significantes entre $(\mathbf{A})$ a expressão de AIRE ou (B) de Foxp3 e o sexo dos pacientes (feminino $n=9$ e masculino $n=6$ ). 
Análises de correlação entre a expressão das proteínas AIRE e Foxp3 e a idade dos pacientes

As análises de correlação de Pearson (intervalo de confiança 95\%) foram realizadas com a finalidade de analisar uma possível ligação entre a idade dos pacientes e a expressão de AIRE ou Foxp3. Os resultados mostraram não haver correlação significante entre a expressão destas proteínas e a idade dos pacientes (Figura 21). Na figura, as idades foram expressas em $\log _{10}$ para melhor visualização dos dados.

A

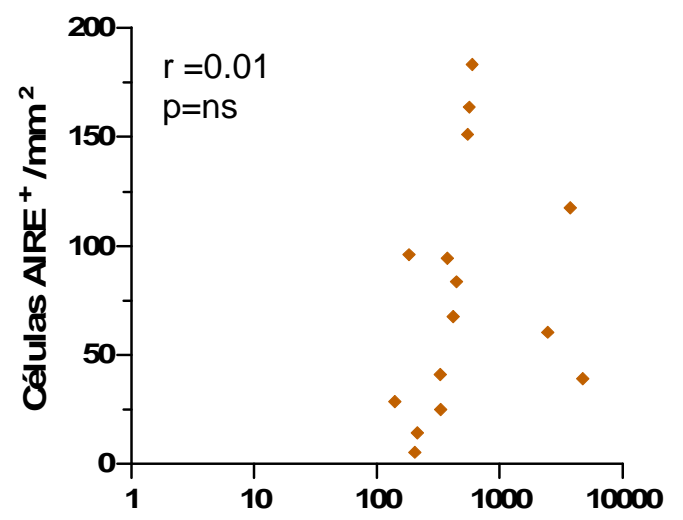

B

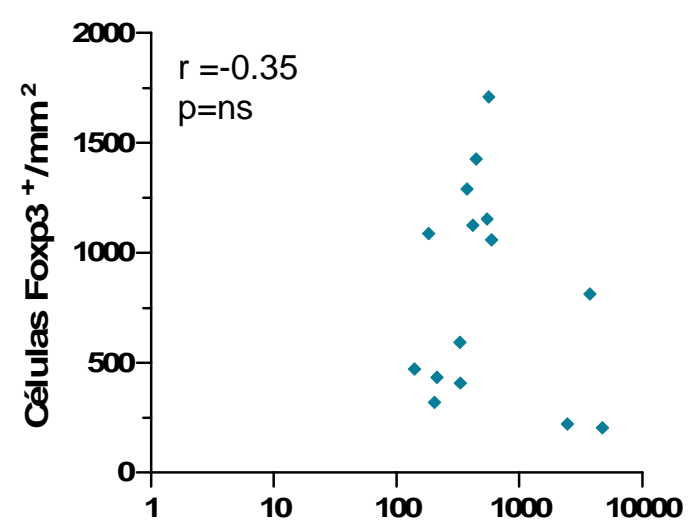

Figura 21. Correlação de Pearson mostrando não haver correlação significante entre a idade dos pacientes e a expressão de (A) AIRE e de (B) Foxp3. 
Análise estatística das diferenças de expressão das proteínas AIRE e Foxp3 entre os grupos SD e controle

Os dados obtidos com as contagens de células $\mathrm{AIRE}^{+}$e $\mathrm{Foxp}^{+}$em timos de pacientes com SD $(n=15)$ foram comparados com os dados dos timos do grupo controle $(n=46)$. Os resultados mostram uma clara e significante diferença $(p<0.0001)$ de número de células expressando AIRE entre os grupos SD e controle (Figura 22A). Em relação à expressão de Foxp3, os resultados mostraram que não há diferença estatisticamente significante entre os grupos (Figura 22B).

A

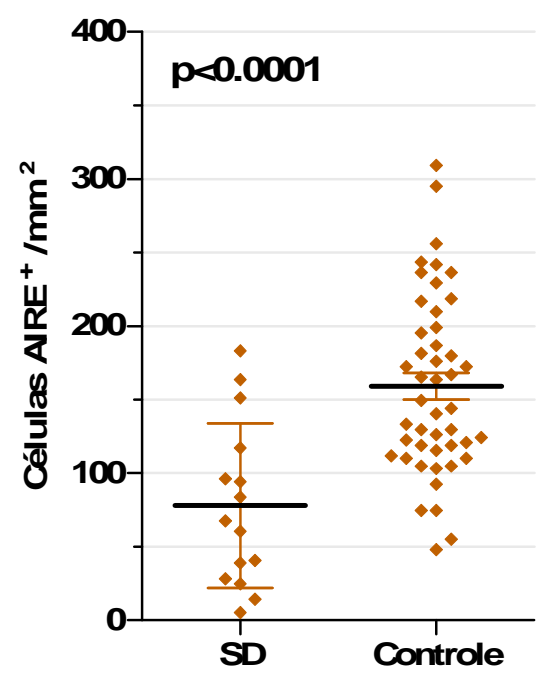

B

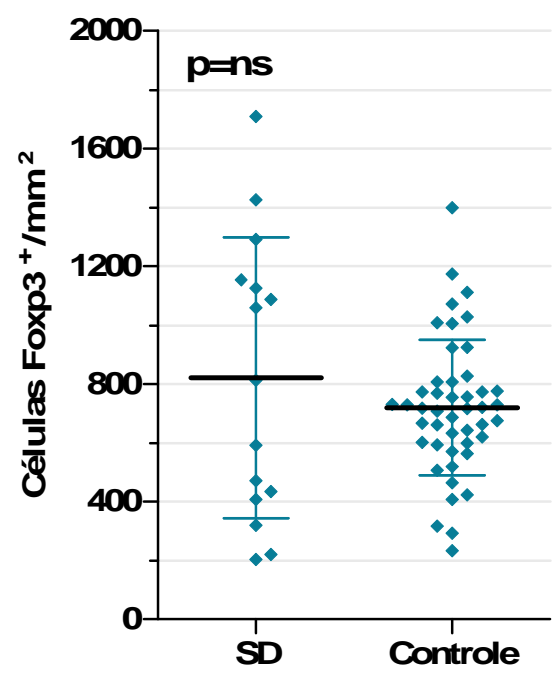

Figura 22. Análise estatística pelo teste de Mann-Whitney. Em (A) observa-se uma diferença significante $(p<0.0001)$ de expressão de AIRE entre os grupos SD e controle, e em (B) não foram encontradas diferenças significantes entre os grupos em relação à expressão de Foxp3. 
Possíveis ligações entre o número de células epiteliais expressando AIRE e de timócitos Foxp $^{+}$foram avaliadas através do teste estatístico de correlação de Pearson. A figura 23 apresenta o resultado da análise, que demonstra haver uma correlação significante entre a expressão destas proteínas $/ \mathrm{mm}^{2}$ de medula no grupo $\operatorname{SD}(r=0.75 ; p=0.001)$.

A análise de correlação entre expressão de AIRE e de Foxp3 nos timos do grupo controle (Capítulo 2, Figura 13) foi inserida na figura 23 para proporcionar uma melhora visualização dos resultados entre os grupos.

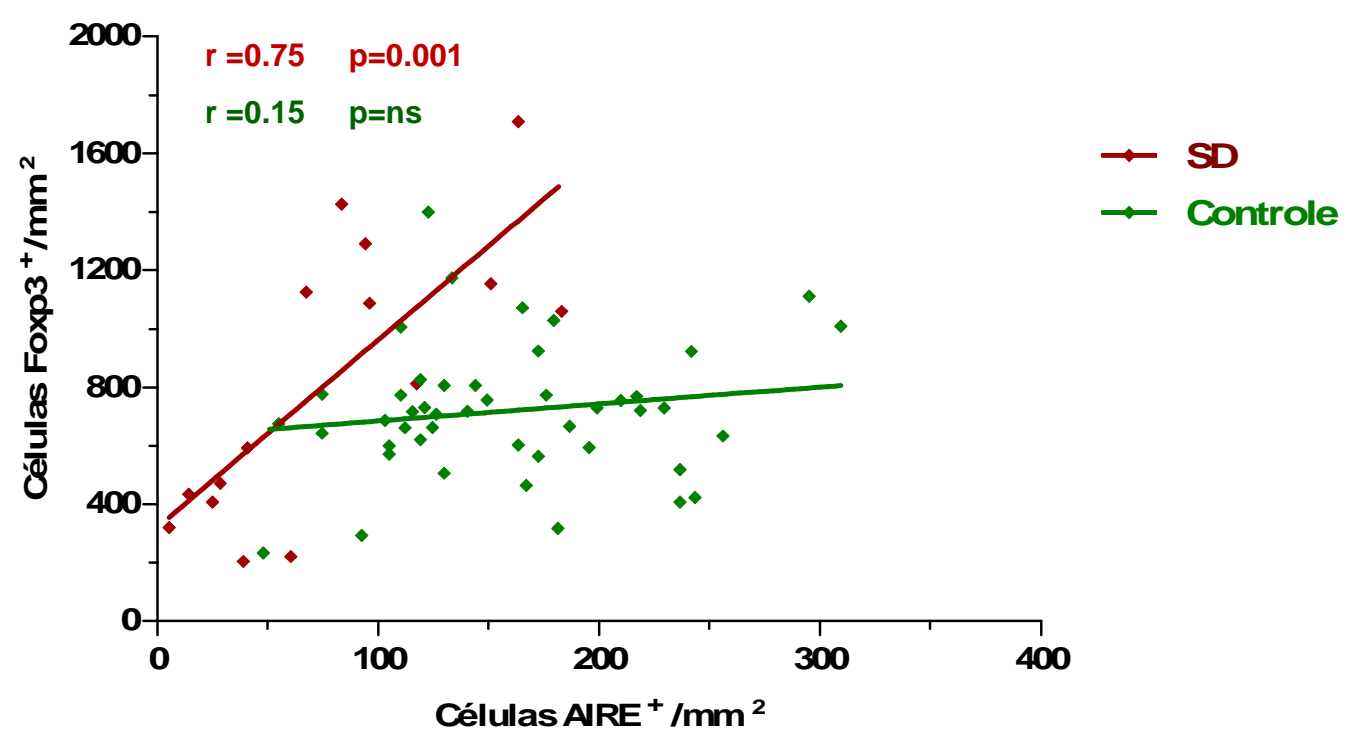

Figura 23. Correlação de Pearson mostrando o aumento significante de Foxp3 concomitante com o aumento do número de células $\mathrm{AIRE}^{+}$nos timos do grupo $\mathrm{SD}(r=0.75 ; p=0.001)$; no grupo controle há um leve aumento não significante $(r=0.15 ; p=n s)$. 


\subsection{Discussão}

Em nosso estudo, observamos ao microscópio algumas alterações morfológicas nos timos do grupo SD corados pelo método de HE (Figura 14), principalmente a redução do número de timócitos, bem evidente nas regiões medular e cortical. O padrão de distribuição de células epiteliais, dendríticas, macrófagos e timócitos $\mathrm{CD}^{+}$foi avaliado em três timos deste grupo, selecionados aleatoriamente. Como exemplificado na figura 15, os timos estudados apresentaram um padrão de marcação de células intratímica semelhante ao observado nos timos do grupo controle (Figura 4). Ao contrario do que foi descrito por Larocca et al. (1990), que observou uma acentuada diminuição de células dendríticas $S 100^{+}$nos timos de indivíduos com SD, observamos uma distribuição semelhante à descrita em timos do grupo controle, apresentando apenas uma leve redução do número total de células positivas. O número de timócitos $\mathrm{CD}^{+}$e macrófagos foi levemente diminuído, aparentemente, proporcional à redução celular total encontrada nesses timos. As células epiteliais dos timos do grupo SD apresentam distribuição e número, aparentemente, semelhante aos timos controle. Os dois timos com maiores alterações morfológicas não foram analisados.

Após marcações dos tecidos com anti-AIRE, observamos ao microscópio que os timos provenientes de crianças com SD apresentaram menor número de células expressando AIRE, bem como, marcação mais tênue de AIRE no núcleo das células positivas (Figura 16A), em comparação com os timos do grupo controle (Figura 16B). Esta diferença de expressão entre os grupos foi confirmada com o procedimento de contagem de células $\mathrm{AIRE}^{+}$por $\mathrm{mm}^{2}$ de medula tímica e análise estatística (Figura 22A).

Dentro do grupo SD foi observado um alto coeficiente de variação ( $C V=72 \%)$ do número de células $\mathrm{AIRE}^{+}$por $\mathrm{mm}^{2}$ de medula tímica (Figura 18A). Quando os timos foram separados por faixa etária (menores e maiores de um ano de vida) e analisados por Mann-Whitney, os resultados mostraram que as crianças com idade inferior a um ano apresentam uma expressão de AIRE significantemente diminuída ( $p=0.01$ ), em comparação com os pacientes maiores de um ano (Figuras 19A). Estes resultados podem sugerir que a expressão normal de AIRE nos primeiros 
meses de vida, fundamental para o estabelecimento da tolerância central, está prejudicada nos pacientes com SD.

Não foram encontradas diferenças significantes entre a expressão de AIRE e o sexo dos pacientes (Figuras 20A). Também não foram encontradas correlações entre expressão de AIRE e a idade dos pacientes (Figura 21A).

Indivíduos com síndrome de Down apresentam aproximadamente 80 fenótipos clínicos com incidência e gravidade altamente variáveis. Desde que a base genética da síndrome de Down foi descrita, entender a relação entre o desequilíbrio de dosagem genética e o fenótipo associado tem sido o principal alvo dos estudos da trissomia do cromossomo 21 humano (HC21). Teoricamente, espera-se que o HC21 produza uma ampliação de transcrição de mRNA proporcional ao número de cópias cromossomais na trissomia, ou seja, um aumento de $50 \%$, entretanto, esta expressão parece ser extremamente variável. Yahya-Graison et al. (2007) estudaram a expressão de 145 genes, 58 ORFs (Open Reading Frame), 118 predições, em células linfoblastóides humanas, provenientes de portadores de SD e controles, e demonstraram esta alta variabilidade de expressão gênica na trissomia do cromossomo 21. Ainda neste estudo, os autores descrevem genes que são expressos dentro do esperado na trissomia (ou seja, 50\% aumentado), genes que são amplificados (acima de 50\%), genes que expressam em níveis similares a amostras controle, e genes compensados (abaixo do expresso pelo controle); segundo os autores, AIRE é um destes genes altamente compensados, ou seja, menos expresso (down regulated). Teoricamente, uma possível explicação para a baixa expressão de AIRE nestes timos seria o bloqueio do promotor do gene AIRE através de metilação, uma vez que há ao menos dois genes que codificam metiltransferases no cromossomo 21 (Yamada et al., 2004). Estes genes podem estar superexpressos na trissomia e metilando gene AIRE que, por sua vez, só é expresso quando tem o promotor completamente desmetilado (Murumagi et al., 2003). Além disto, a proteína AIRE atua como fator transcricional de genes com o DNA desmetilado (Org et al., 2008), a metilação provoca o silenciamento dos genes alvo. Estes dados tornam esta especulação interessante, e apontam para a necessidade de investigação das condições de metilação do promotor de AIRE na trissomia do cromossomo 21 . Os dados destes trabalhos condizem com os nossos 
achados, uma vez que observamos um fenótipo de expressão da proteína AIRE significantemente $(p=0.0001)$ mais baixo, nos timos de pacientes com trissomia do cromossomo 21, em comparação com o grupo controle (Figura 22A). Além disto, sabe-se que pacientes com SD apresentam alta prevalência de autoimunidades, em vários aspectos similares àquelas observadas em pacientes APECED como tireoidite, diabetes tipo I e doença celíaca, entretanto, até o momento nenhum estudo descreveu a deficiência de AIRE como sendo o possível causador do defeito na seleção negativa dos timócitos destes pacientes.

Em relação à diferenciação de células Treg naturais, a expressão de Foxp3 nos timos dos pacientes do grupo SD (Figura 17) foi semelhante à observada em timos do grupo controle (Figura 8), ou seja, foram vistos numerosos timócitos expressando Foxp3 na medula de todos os timos do grupo SD estudados. O número de células Foxp3 $3^{+}$por $\mathrm{mm}^{2}$, encontrado no timo de cada indivíduo, tem uma alta variação $(C V=58 \%)$ dentro do grupo SD (Figura 18B), entretanto, não houve diferença significativa de expressão de Foxp3 entre os grupos SD e controle (Figura 22B).

Assim como observado em relação à expressão de AIRE no grupo SD, foi encontrado menor número de células Foxp ${ }^{+}$nos timos de crianças com idade inferior a um ano $(n=6)$, entretanto, esta diferença não foi estatisticamente significante entre os grupos etários (menores e maiores de um ano de idade) (Figuras 19B). As médias da expressão de Foxp3 entre os sexos dos pacientes não teve diferença significativa (Figuras 20B). Nenhuma correlação foi evidenciada entre a expressão de Foxp3 e a idade dos pacientes (Figura 21B).

O papel de AIRE sobre a diferenciação de células Treg naturais ainda não está claro. Alguns achados sugerem que AIRE influencia apenas no repertório do TCR, mas não no número total de células, embora Kekalainen et al. (2007) tenham encontrado baixas proporções de células Treg em pacientes com APECED. Por outro lado, pacientes com IPEX (immune dysregulation polyendocrinopathyenteropathy-X-linked inheritance), desordem causada por mutações no gene Foxp3, apresentam fenótipos autoimunes com natureza e agressividade diferentes das características observadas em pacientes com APECED, sugerindo mecanismos de controle independentes. Os nossos achados confirmam que a deficiência de AIRE 
não prejudica a produção de células Treg naturais no timo humano, uma vez que foram encontrados números de células Foxp $3^{+}$em níveis normais nos timos de pacientes com SD (Figura 22B), mesmo naqueles que apresentam raras células $\mathrm{AIRE}^{+}$(dado não mostrado). Entretanto, observamos uma correlação muito significante $(r=0.75 ; p=0.001)$ entre a expressão de AIRE e de Foxp3 nos timos do grupo SD (Figura 23), sugerindo uma compensação positiva a favor da diferenciação de células Treg naturais, possivelmente relacionada à AIRE e/ou à trissomia do cromossomo 21. Em teoria, uma possível explicação para esta correlação entre AIRE e Foxp3 - sem prejuízo no número total de células Foxp3 ${ }^{+}$, mesmo nos timos com menos células $\mathrm{AIRE}^{+}$, e podendo-se observar um aumento diretamente proporcional a expressão de AIRE - pode ser atribuída à presença do microRNA (miRNA) miR-155 no cromossomo 21, pois além de ser essencial para a produção de células Treg narurais (Kohlhaas et al., 2009; Zhou et al., 2009), o miR155 foi encontrado superexpresso (up regulated) em cérebro e coração de pacientes com trissomia do 21 (Kuhn et al., 2008), podendo apresentar esse aumento também em outros órgãos como o timo. Neste prisma, a superexpressão miR-155 pode estar compensando a possível perda de Treg causada pela diminuição de AIRE nos timos do grupo SD. 
CAPítulo 4 


\section{ESTUDO DA DISTRIBUIÇÃO DE LIGANTES E RECEPTORES NOTCH NO TIMO HUMANO}

\subsection{Introdução}

Notch é uma via de sinalização celular altamente conservada, composta por ligantes e receptores, essencial para a regulação de uma variedade de eventos em diversos aspectos da diferenciação celular - como o direcionamento do desenvolvimento, a localização e o número de células, através dos mecanismos de proliferação e sobrevivência - durante o desenvolvimento de organismos multicelulares (Maillard et al., 2005).

Em mamíferos são encontrados quatro receptores Notch (N1, N2, N3 e N4), compostos por domínios proteicos conservados, e dois grupos de ligantes, um homólogo ao Serrate (Jagged1 e jagged2; em humanos, Jag1 e Jag2) e outro homólogo ao Delta (DIl1, DII3 e DII4). Serrate e Delta são os dois ligantes Notch encontrados em Drosophila, onde a via Notch foi descrita pela primeira vez.

Receptores e ligantes Notch são complexos proteicos inseridos na membrana celular (Figura 24).Os receptores Notch são formados por uma porção extracelular que consiste de 29 a 36 moléculas de EGF-like (epidermal growth factor-like), repetidas em sequência, capazes de interagir com a região DSL (Delta, Serrate e Lag-2) dos ligantes; e três repetições de LIN12 (lineage defective-12), que impedem a sinalização independente de ligante. A porção intracelular NICD (Notch intracellular domain), que medeia a transdução de sinais, é composta por: domínios RAM (RBP-JK-associated module) e repetições subsequentes de ANK (ankyrin), os quais interagem com proteínas efetoras, como as CSL (em humanos, CBF1; Drosophila, Suppressor of Hairless; C. elegans, Lag-1); um domínio de transativação (TAD); e um domínio C-terminal denominado PEST, que regula a estabilidade da proteína. Os receptores diferem entre si, principalmente, em número de repetições de EGF-like e na sequência localizada entre as regiões ANK e PEST (Maillard et al., 2005). 
Receptores Notch

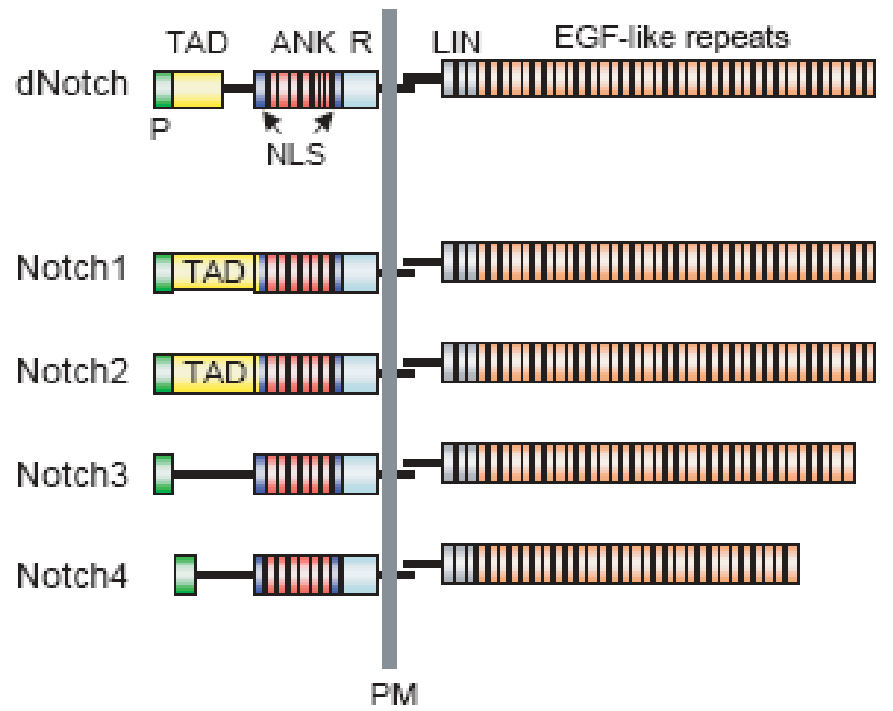

Ligantes Notch

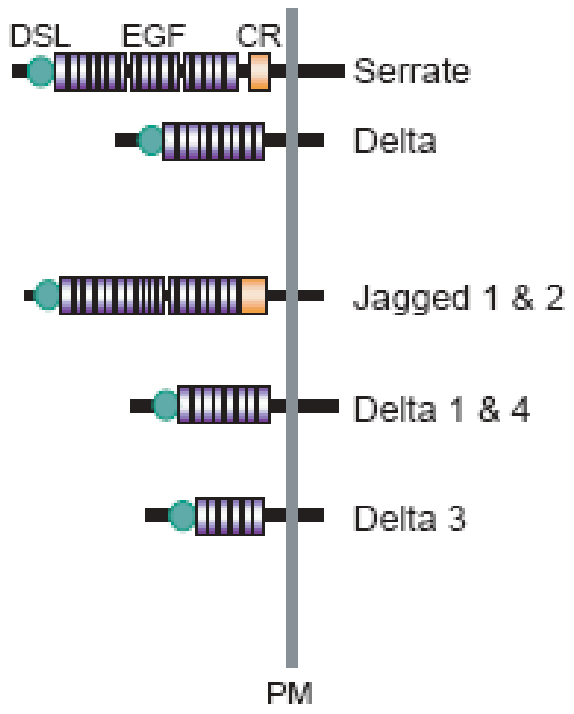

Figura 24. Esquema estrutural dos ligantes e receptores Notch. Receptor Notch de Dosophila (dNotch); Membrana plasmática (PM); domínio RAM (R); PEST (P). FONTE: Radtke et al. (2004).

Os ligantes Notch são proteínas transmembrânicas, contendo o domínio extracelular composto por uma região rica em cisteína $(C R)$, repetições sequenciais do EGF-like, um domínio DSL e um peptídeo sinal. O domínio intracelular é pouco conservado, porém, exerce um papel importante, pois a sua deleção conduz à perda de função.

A sinalização mediada por Notch é iniciada após interação entre ligante e receptor expressos na superfície de células adjacentes (Figura 25). Esta ligação induz a uma série de clivagens, resultando na translocação do NICD para o núcleo, onde ativa a transcrição dos genes alvo, como HES (Hairy/Enhancer of Split) e HERP (HES-related repressor protein), responsáveis pela inibição da expressão e/ou função de outros genes (Le Borgne et al., 2005; Maillard et al., 2005; Fiuza e Arias, 2007; Tien et al., 2009). Os determinantes de especificidade entre ligantes e receptores são pouco compreendidos. Sabe-se que diferentes receptores são capazes de interagir com o mesmo ligante, entretanto, há uma questão que 
permanece: os receptores Notch apresentam, intrinsecamente, respostas distintas para o mesmo ligante, ou o resultado final da ativação de um receptor em particular depende apenas do ligante que o estimulou?

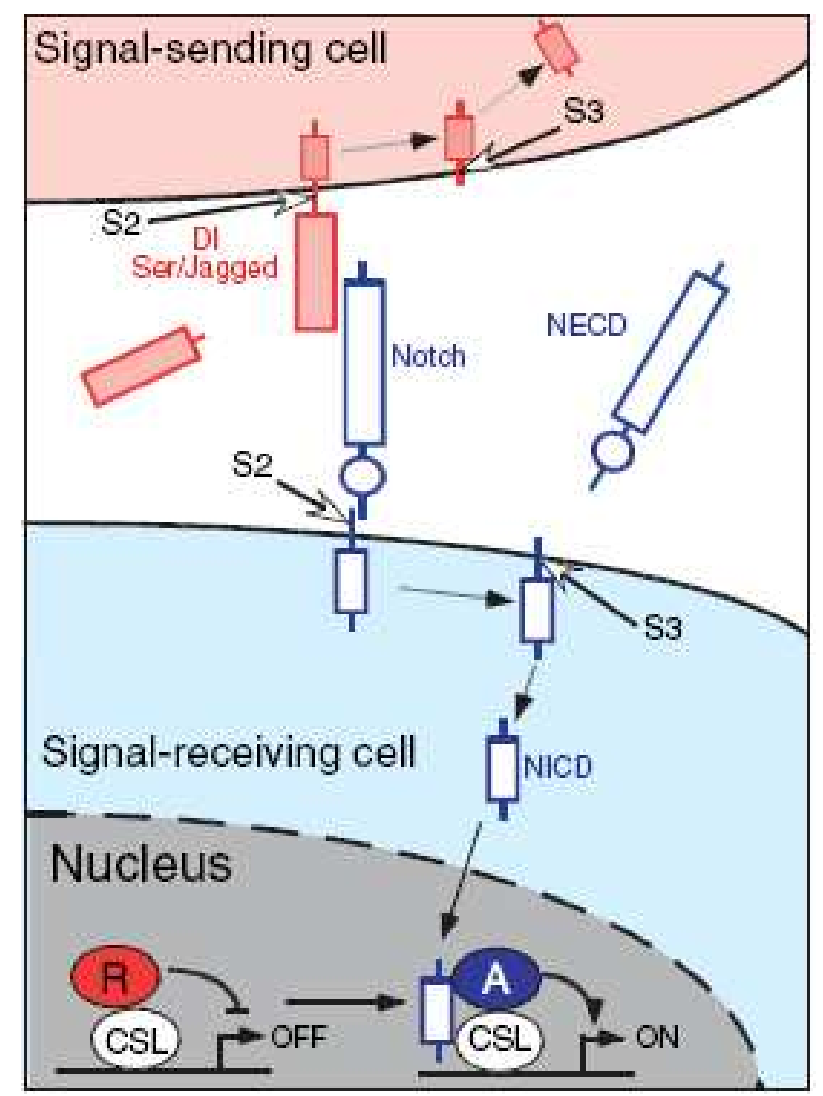

Figura 25. Representação esquemática da sinalização mediada por Notch. Sítios de clivagem (S1, 2 e 3).

FONTE: Le Borgne et al. (2005).

Receptores e ligantes Notch são amplamente expressos em embriões de mamíferos durante a organogênese. Os sinais Notch regulam o comprometimento celular de tecidos derivados das três camadas germinativas (ectoderma, mesoderma e endoderma). Deleções ou mutações nos genes que codificam ligantes e/ou receptores Notch podem levar a defeitos na somitogênese, vasculogênese, neurogênese e, geralmente, são letais ainda no início do desenvolvimento embrionário. A desregulação destes genes conduz ao surgimento de doenças 
graves como câncer, e/ou mesmo à letalidade (Harper et al., 2003; Radtke et al., 2010).

Na última década, tornou-se evidente que sinais Notch têm um importante papel no desenvolvimento e na manutenção dos sistemas hematopoiético e imunológico. Várias evidências sugerem que Notch é um importante modulador da resposta imune mediada por linfócitos $T$ (Radtke et al., 2010). No timo, as sinalizações mediadas por Notch são essenciais para o direcionamento do desenvolvimento de células progenitoras linfoides, assim como para a expansão e autorrenovação celular. Timócitos e células estromais coexpressam amplamente receptores e ligantes Notch, bem como os seus moduladores, entretanto, a localização e identidade precisas das células que recebem os sinais são ainda conflitantes (Harper et al., 2003; Maillard et al., 2005). Durante a ontogenia de linfócitos T, a função de Notch melhor estabelecida refere-se ao comprometimento celular. Assim, as CTH pluripotentes (com potencial para se tornar células T, B, dendríticas, NK, macrófago), provenientes da medula óssea, recebem sinais Notch e se tornam comprometidas a originar linfócitos T. Além do comprometimento, outros eventos de diferenciação são mediados pela via de sinalização Notch, como a regulação do rearranjo do gene TCR- $\beta$, a decisão entre as linhagens de linfócitos T $\alpha \beta$ sobre $\gamma \delta$, CD4 versus CD8 e Th2 versus Th1 (Robey et al., 1996; Washburn et al., 1997; Wolfer et al., 2002; Maillard et al., 2005; Kappes et al., 2005; De La Coste et al., 2006; Tanigaki e Honjo, 2007; Plum et al., 2008; Amsen et al., 2009; Radtke et al., 2010).

O receptor $\mathrm{N} 1$ regula vários estágios do desenvolvimento de células $\mathrm{T}$ no timo (Guidos, 2002), enquanto N2 regula a maturação de células B no baço (Saito et al., 2003).Vários estudos demonstram que o receptor N1 é essencial para o sucesso da timopoiese. A inativação de $\mathrm{N} 1$ provoca um completo bloqueio do desenvolvimento de células $T$ no timo, indicando que outros membros da família Notch não são capazes de compensar a perda de N1 in vivo (Radtke, et al., 1999). Esta exigência única de N1 durante a timopoiese não é bem compreendida, uma vez que N2 e N4 são capazes de induzir o desenvolvimento de linfócitos T in vitro, na ausência de N1, fato que descarta a inabilidade intrínseca destas moléculas. A ativação dos receptores N1 e N3 é crucial para a regulação da expressão e função dos sinais 
pré-TCR nos timócitos em estágio de desenvolvimento DN3 (Bellavia et al., 2003). O receptor N4 parece estar envolvido na diferenciação de linfócitos T regulatórios ( $\mathrm{Ng}$ et al., 2001).

O ligante Notch mais estudado na timopoiese é o Dll1. Em camundongo, este ligante é expresso amplamente no estroma tímico, em particular na região córticomedular, entretanto, a sua inativação não bloqueia o desenvolvimento de células $T$, sugerindo um papel redundante entre Dll1 e outro ligante Notch, como o Dll4 (Maillard et al., 2005). O ligante DII3 não é capaz de se ligar aos receptores Notch, mas atuam na modulação da sinalização (Ladi et al., 2005). Os ligantes Jagged parecem estar envolvidos na diferenciação intratímica de células $T \gamma \delta$ e Th2 na periferia (Amsen et al., 2009; Radtke et al., 2010).

Muitos dos mecanismos de regulação, interações e ação dos sinais Notch permanecem pouco conhecidos, bem como a localização e identidade precisa das células que recebem os sinais e seus possíveis efeitos. Grande parte dos estudos sobre o papel dos sinais Notch no desenvolvimento de linfócitos $T$ foram desenvolvidos em modelo animal ou cultivo celular. Até o momento, não está descrita a distribuição de Notch no timo humano.

Tendo-se em vista a importância dos sinais Notch para o desenvolvimento de timócitos, bem como a falta de dados sobre a expressão de Notch no timo humano, propomos o estudo inédito da distribuição de ligantes e receptores Notch nas diferentes regiões tímicas e nas distintas subpopulações celulares do timo humano.

\subsubsection{Objetivos}

- Estudar, através de ensaios de imunohistoquímica, a expressão dos ligantes e receptores Notch em timos provenientes de crianças portadoras de cardiopatias com malformações isoladas (grupo controle) e de crianças com síndrome de Down. 


\subsection{Material e métodos}

Para marcar os receptores e ligantes Notch no timo humano, foram realizados ensaios de imunohistoquímica de fluorescência (marcações simples) e cromogênica (marcações simples de duplas). Todo o procedimento, desde a preparação dos cortes histológicos, os ensaios de imunomarcação, até a montagem das lâminas foi realizado como descrito detalhadamente no Capítulo 2 (ver 2.2).

Sete espécimes de timo do grupo controle e três do grupo SD (Síndrome de Down), apresentados na tabela 4, foram estudados por imunomarcações simples utilizando os diferentes antissoros anti-Notch (Tabela 5). Dentre os timos estudados, três do grupo controle e um do grupo SD foram avaliados também por marcações duplas, com a finalidade de identificar os diferentes tipos celulares intratímicos capazes de expressar Notch, como: células dendríticas, epiteliais, macrófagos e células-tronco. Os cortes tímicos imunomarcados foram analisados ao microscópio, em vários aumentos, e registrados fotograficamente.

Tabela 4 - Identificação dos timos estudados quanto à expressão de Notch.

\begin{tabular}{lcccc}
\hline REGISTRO & IDADE (DIAS) & SEXO & CARDIOPATIA & GRUPO \\
\hline $3233154^{*}$ & 6 & M & CIV & Controle \\
\hline 3182274 & 90 & M & TF/CAV/VDDS & Controle \\
\hline $3225755^{*}$ & 147 & F & CAV & Controle \\
\hline 3660729 & 213 & F & CAV & SD \\
\hline $3162877^{*}$ & 225 & M & CIV & Controle \\
$3657361^{*}$ & 326 & F & CIV & SD \\
3081443 & 735 & M & CIV & Controle \\
3082849 & 1855 & M & CIA & Controle \\
\hline 3324370 & 2474 & M & CIV & SD \\
3175472 & 2911 & $M$ & CIA & Controle \\
\hline
\end{tabular}

* Timos estudados por imunomarcações duplas

CAV - Comunicação atrioventricular

TF - Tetralogia de Fallot/Comunicação aortopulmonar

CIA - Comunicação interatrial

VDDS - Ventrículo direito com dupla via de saída

CIV - Comunicação interventricular 
$\mathrm{Na}$ tabela 5 estão descritos os anticorpos utilizados para a marcação de ligantes e receptores Notch, bem como os marcadores específicos para identificar os tipos celulares intratímicos.

Tabela 5. - Anticorpos primários utilizados para estudar a distribuição de Notch no timo humano.

\begin{tabular}{|c|c|c|c|c|}
\hline ANTICORPO PRIMÁRIO & HOSPEDEIRO & CONCENTRAÇÃO & FABRICANTE & CÉLULAS ALVO \\
\hline N1 (C-20) & coelho (IgG) & $2,0 \mu \mathrm{g} / \mathrm{mL}$ & Santa Cruz Biotech & - \\
\hline N2 (C651.6DbHN) & rato $(\lg G)$ & $1,0 \mu \mathrm{g} / \mathrm{mL}$ & Hybrid. Bank & - \\
\hline N3 (M-20) & cabra (lgG) & $4,0 \mu \mathrm{g} / \mathrm{mL}$ & Santa Cruz Biotech & - \\
\hline 1N4 (C-19) & cabra (lgG) & $4,0 \mu \mathrm{g} / \mathrm{mL}$ & Santa Cruz Biotech & - \\
\hline Jag1 $(H-114)$ & coelho (IgG) & $2,0 \mu \mathrm{g} / \mathrm{mL}$ & Santa Cruz Biotech & - \\
\hline Jag2 $(H-143)$ & cabra (lgG) & $4,0 \mu \mathrm{g} / \mathrm{mL}$ & Santa Cruz Biotech & - \\
\hline DIl1 (C-20) & cabra (lgG) & $8,0 \mu \mathrm{g} / \mathrm{mL}$ & Santa Cruz Biotech & - \\
\hline DII4 (ab-7280) & coelho (IgG) & $1,0 \mu \mathrm{g} / \mathrm{mL}$ & Abcam & - \\
\hline CD117 (117-R14) & coelho (lgG) & $2,0 \mu \mathrm{g} / \mathrm{mL}$ & Cell Marque & Tronco \\
\hline Pan-cytokeratin (34ßE12) & camundongo (IgG) & $1,0 \mu \mathrm{g} / \mathrm{mL}$ & Dako & Epiteliais \\
\hline CD68 & camundongo (lgG) & $4,0 \mu \mathrm{g} / \mathrm{mL}$ & Dako & Macrófagos \\
\hline$S-100$ & coelho (lgG) & $2,0 \mu \mathrm{g} / \mathrm{mL}$ & Dako & Dendríticas \\
\hline
\end{tabular}

\subsection{Resultados}

Cortes histológicos, de todos os timos utilizados neste estudo, foram submetidos a imunomarcações simples com os antissoros específicos para cada receptor e ligante Notch. Entretanto, para a identificação dos tipos celulares que expressam os distintos Notch, nas diferentes regiões do timo, foram realizadas marcações duplas em quatro dos dez espécimes estudados (sendo um do grupo SD e três do controle).

Ao microscópio, pudemos observar a marcação da maioria das células intratímicas com o anti-N1 (Figura 26A), incluindo as CET tipo VI dos corpúsculos de Hassall, o endotélio dos vasos situados na região córtico-medular e alguns vasos da região septal (Figura 26B). No córtex foram observados macrófagos com o 
citoplasma apresentando pequenas vesículas contendo N1 em abundância (Figura 26C).
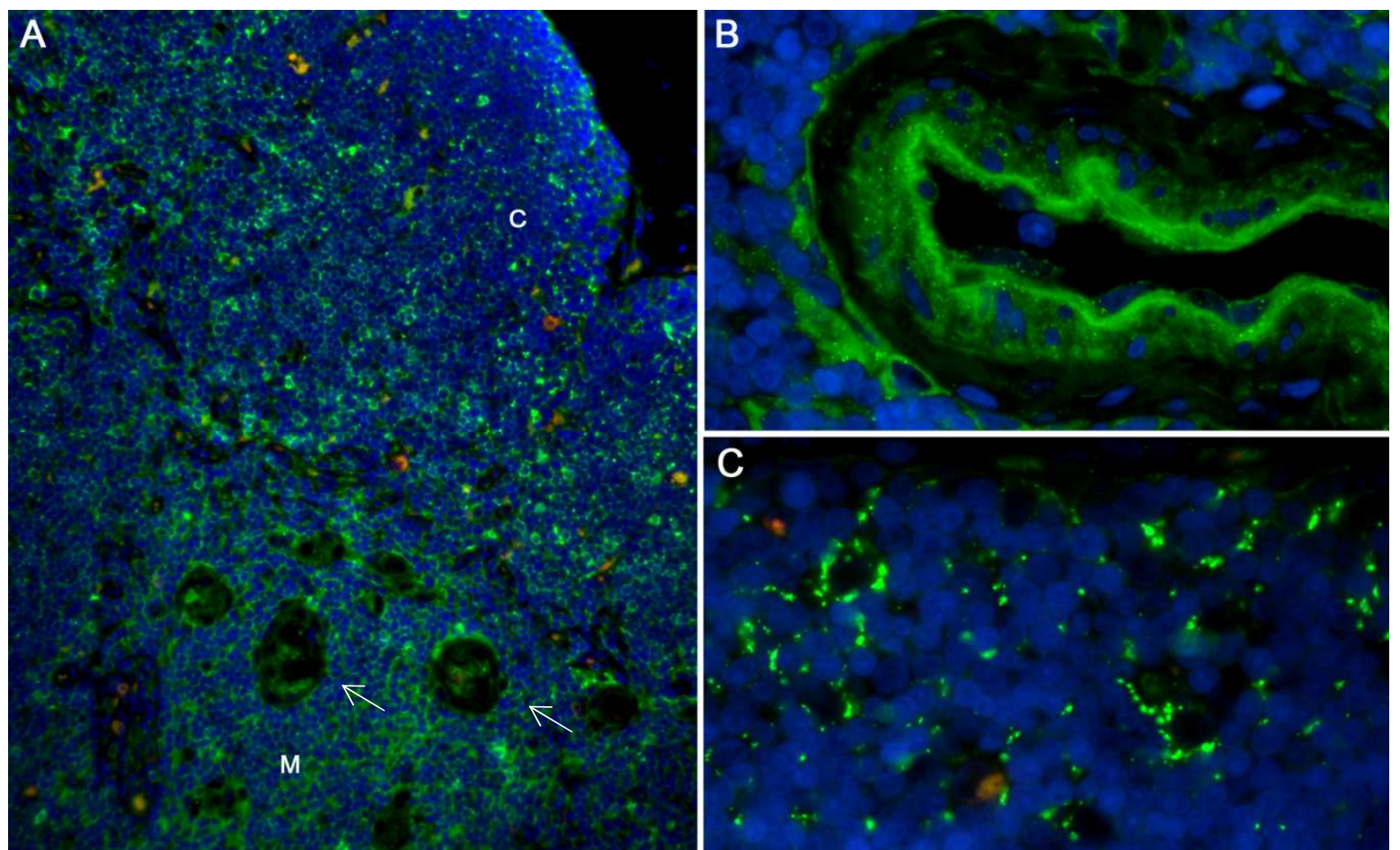

Figura 26. Imunohistoquímica de fluorescência para detecção de N1. Em A. observa-se a marcação (verde) de células intratímicas das regiões cortical $(C)$, medular $(M)$ e corpúsculos de Hassall (setas). Em B. está evidenciada a marcação de N1 no endotélio de um vaso sanguíneo. Em C. podemos observar macrófagos da região cortical do timo com marcação puntiforme. Em azul aparecem os núcleos marcados com DAPI. Aumentos de 200x e 630x em B e C.

Entretanto, o principal destaque da marcação de $\mathrm{N} 1$ foi a presença profusa desta proteína em algumas células com morfologia semelhante à de células jovens indiferenciadas, localizadas principalmente nas proximidades dos vasos septais, na periferia subseptal e subcapsular, abundantes nas adjacencias dos vasos da região córtico-medular (Figura 27A), e algumas raras espalhada pelo córtex e medula. Para identificar o tipo celular apresentando esta acentuada expressão de N1, foram realizadas marcações duplas. Os resultados mostraram uma clara colocalização das 
moléculas de N1 e CD117 (Figura 27B), confirmando os indícios morfológicos de que se trata de $\mathrm{CTH}$ expressando $\mathrm{N} 1$.
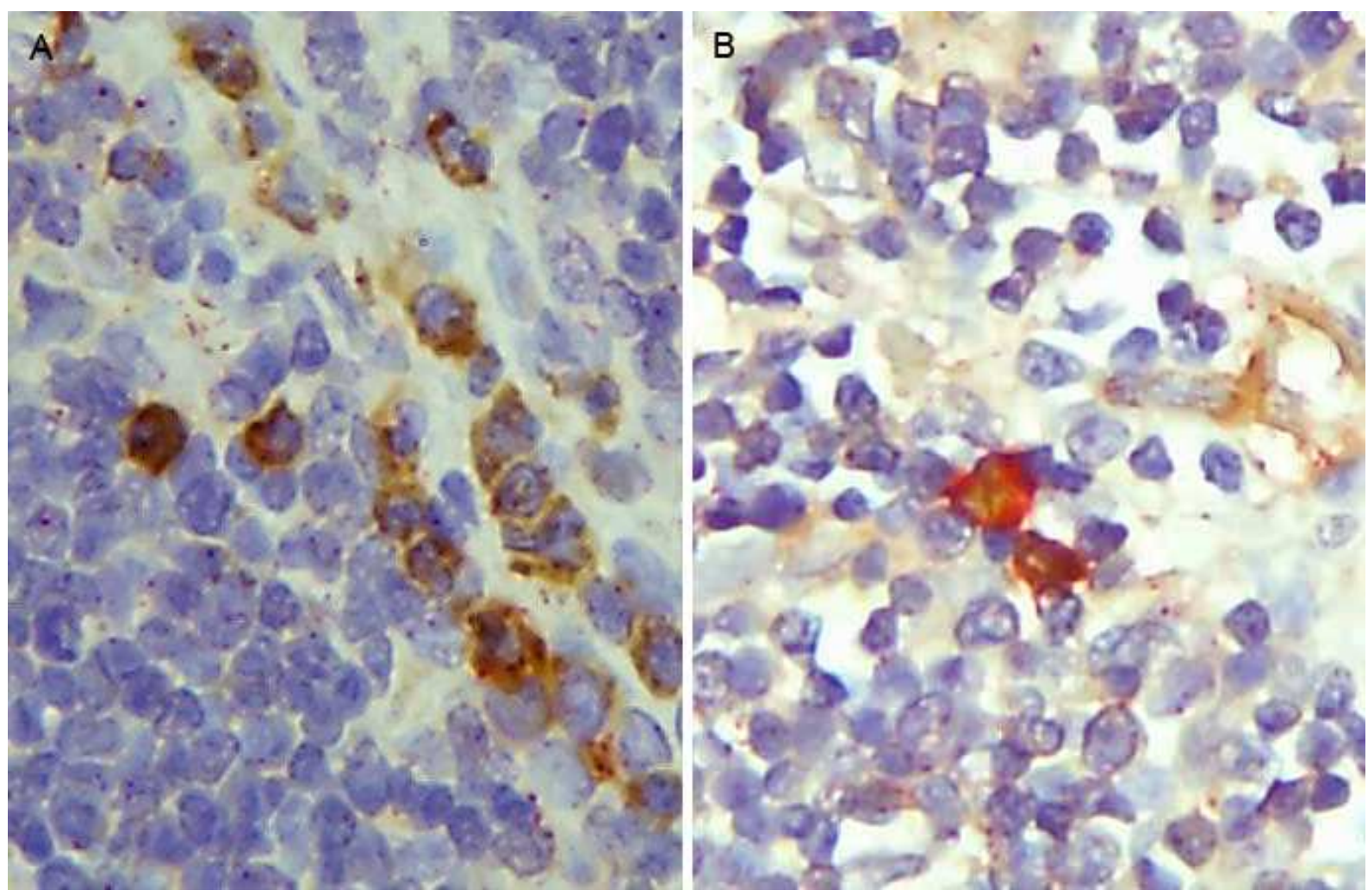

Figura 27. Imunohistoquímica para detecção de N1 em tecido tímico. Em A., marcação simples com anti-N1 mostrando células intensamente marcadas (castanho) na região cortico-medular. Em B., dupla marcação evidenciando a colocalização da expressão de N1 (castanha) e CD117 (rosa). Contracoloração por hematoxilina. Aumento de 400x.

Os timos tratados com anti-N2 apresentaram marcação muito específica e acentuada da membrana celular de CET como: as CET tipo I, que cercam toda a periferia dos lóbulos e septos (Figura 28A), bem como o espaço perivascular dos vasos sanguíneos localizados na região córtico-medulares (Figura 28B); algumas CET medulares; e as CET tipo VI, componentes dos corpúsculos de Hassall (dados não mostrados). Nenhum outro tipo celular foi observado expressando N2 no timo humano. 


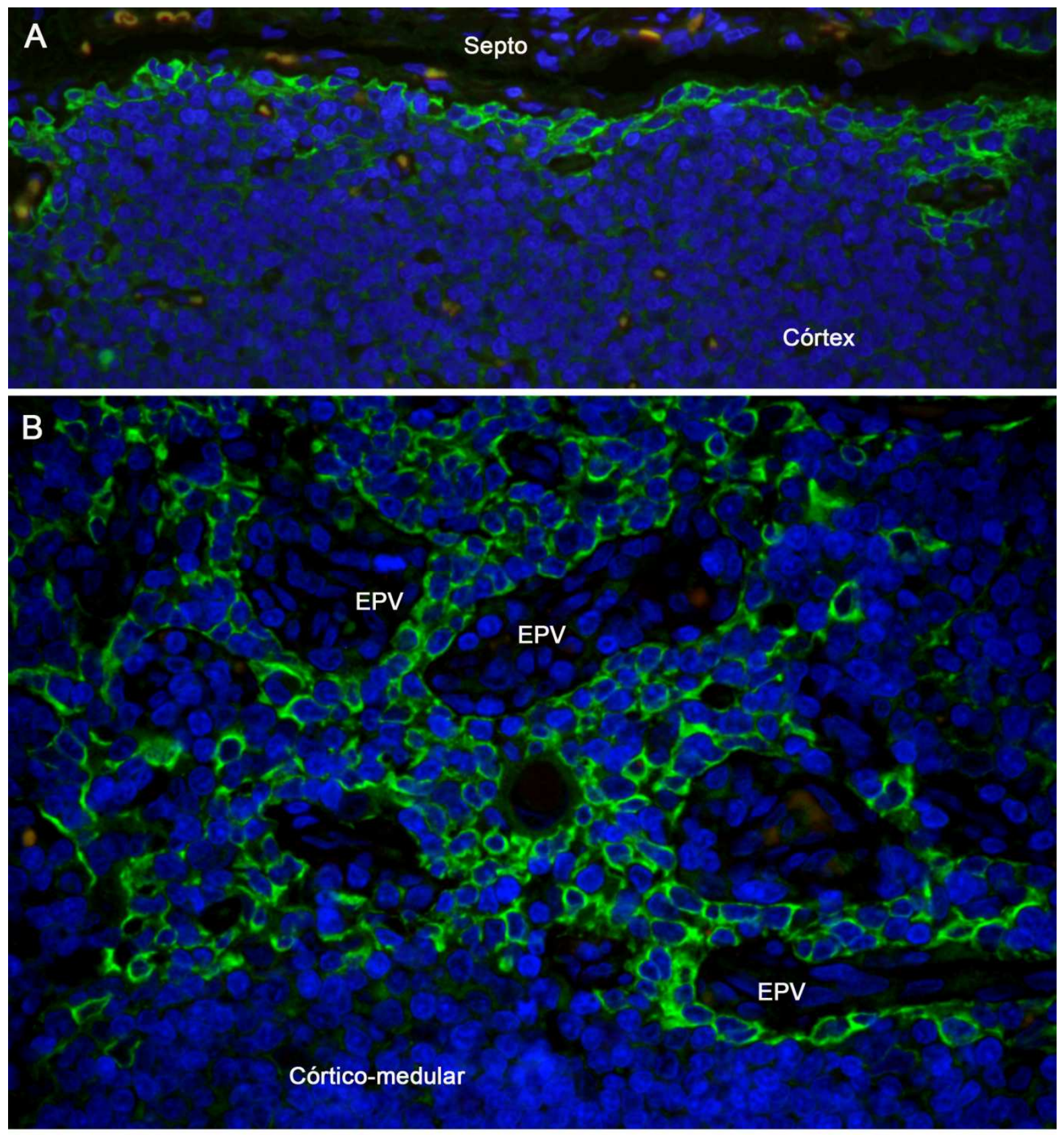

Figura 28. Imunofluorescência (FITC) de tecido tímico tratado com anti-N2, evidenciando a marcação (verde) das células epiteliais das regiões (A) subseptal e (B) perivascular dos vasos córtico-medulares. Espaço prerivascular (EPV). Aumentos de 400x e 630x, respectivamente. 
Nos cortes tímicos submetidos à reação com o antissoro anti-N3 foram observadas marcações apenas das CET tipo VI, componentes dos corpúsculos de Hassall (Figura 29). A marcação foi vista predominantemente no citoplasma celular. Os ensaios de marcação dupla, com anti-pan-citoqueratina e anti-S100, confirmaram que somente CET, e não células dendríticas, expressam N3 nos corpúsculos de Hassall. Em alguns dos timos estudados, foram observados raros timócitos da região medular expressando N3 (dado não mostrado).

Uma tênue marcação do receptor N4 foi evidenciada apenas em alguns timócitos das regiões cortical e medular, e nas CET que compõem os corpúsculos de Hassall (dados não mostrados).

Os cortes tímicos tratados com o antissoro anti-Dll1 apresentaram uma marcação muito tênue de timócitos da região cortical, e de células dendríticas e epiteliais de ambas as regiões, cortical e medular (dados não mostrados).

Os resultados dos ensaios de imunofluorescência utilizando o anti-Dll4 mostraram uma acentuada marcação de timócitos, células epiteliais, dendríticas, endoteliais e macrófagos nas regiões medular e cortical, como exemplificado na figura 30. Na região cortical, muitos macrófagos Dll4 ${ }^{+}$apresentam marcação citoplasmática puntiforme, semelhante ao observado na reação com o N1.

O ligante Jag1 foi evidenciado em ambas as regiões, cortical e medular. Entretanto, a marcação se mostrou predominante em células epiteliais medulares, principalmente na região que circunda os corpúsculos de Hassall (Figura 31). As CET que formam os corpúsculos também aparecem marcadas. Por outro lado, o ligante Jag2 foi encontrado no endotélio de raros vasos pequenos localizados na região septal (Figura 32).

Após ensaios de marcações duplas, foi possível organizar um painel de distribuição de Notch nas regiões e tipos celulares intratímicos (Tabela 6). 


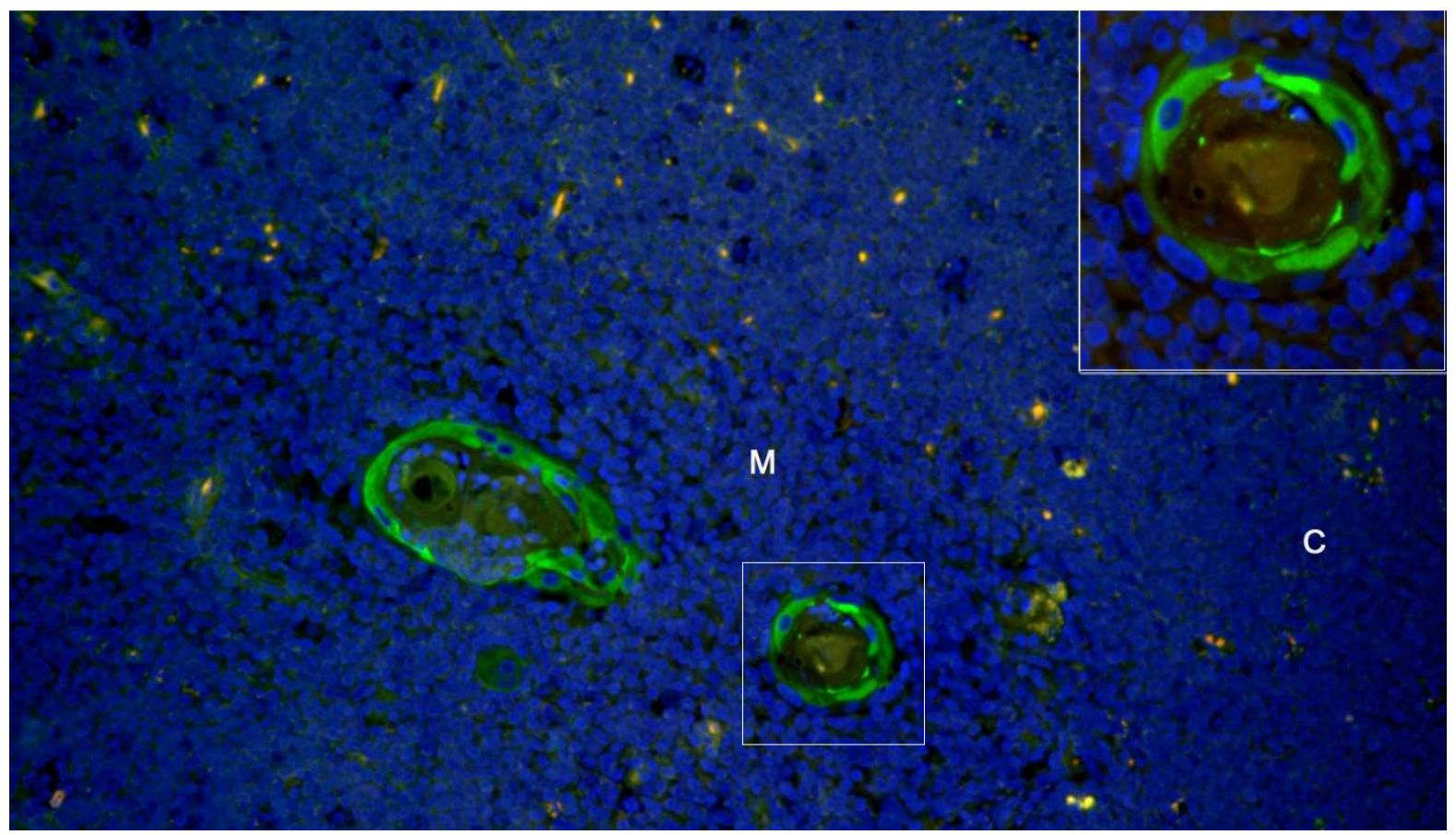

Figura 29. Imunofluorescência (FITC) de corte tímico tratado com anti-N3, evidenciando a marcação das células epiteliais da periferia de dois corpúsculos de Hassall. Ausência de marcações nas demais células das regiões cortical $(C)$ e medular (M) do timo. Aumentos de 200x e 400x (destaque).

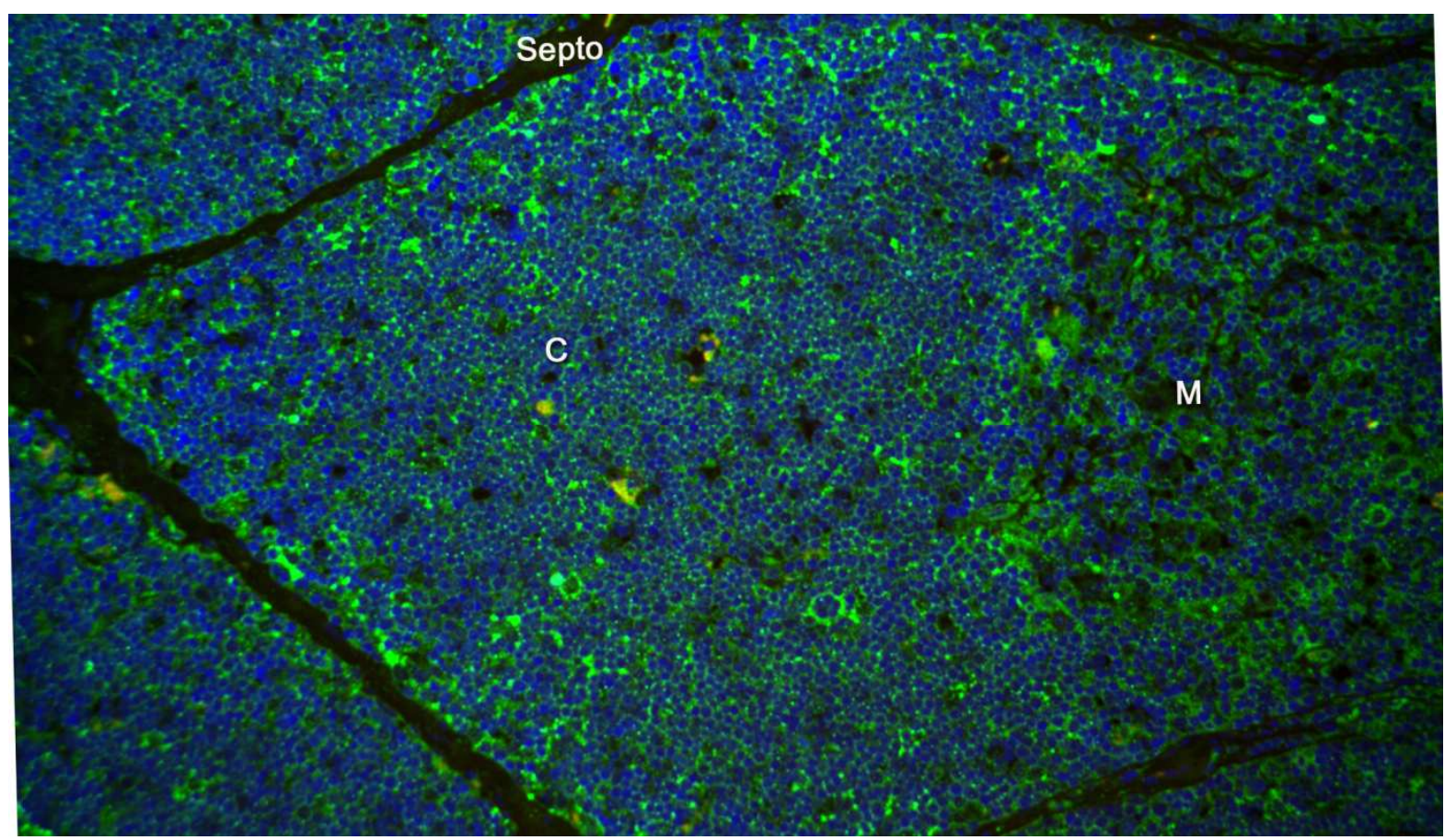

Figura 30. Imunofluorescência (FITC) de corte tímico tratado com anti-Dll4, evidenciado a marcação nas regiões cortical $(C)$ e medular $(M)$ do timo humano. Aumento de $200 x$. 


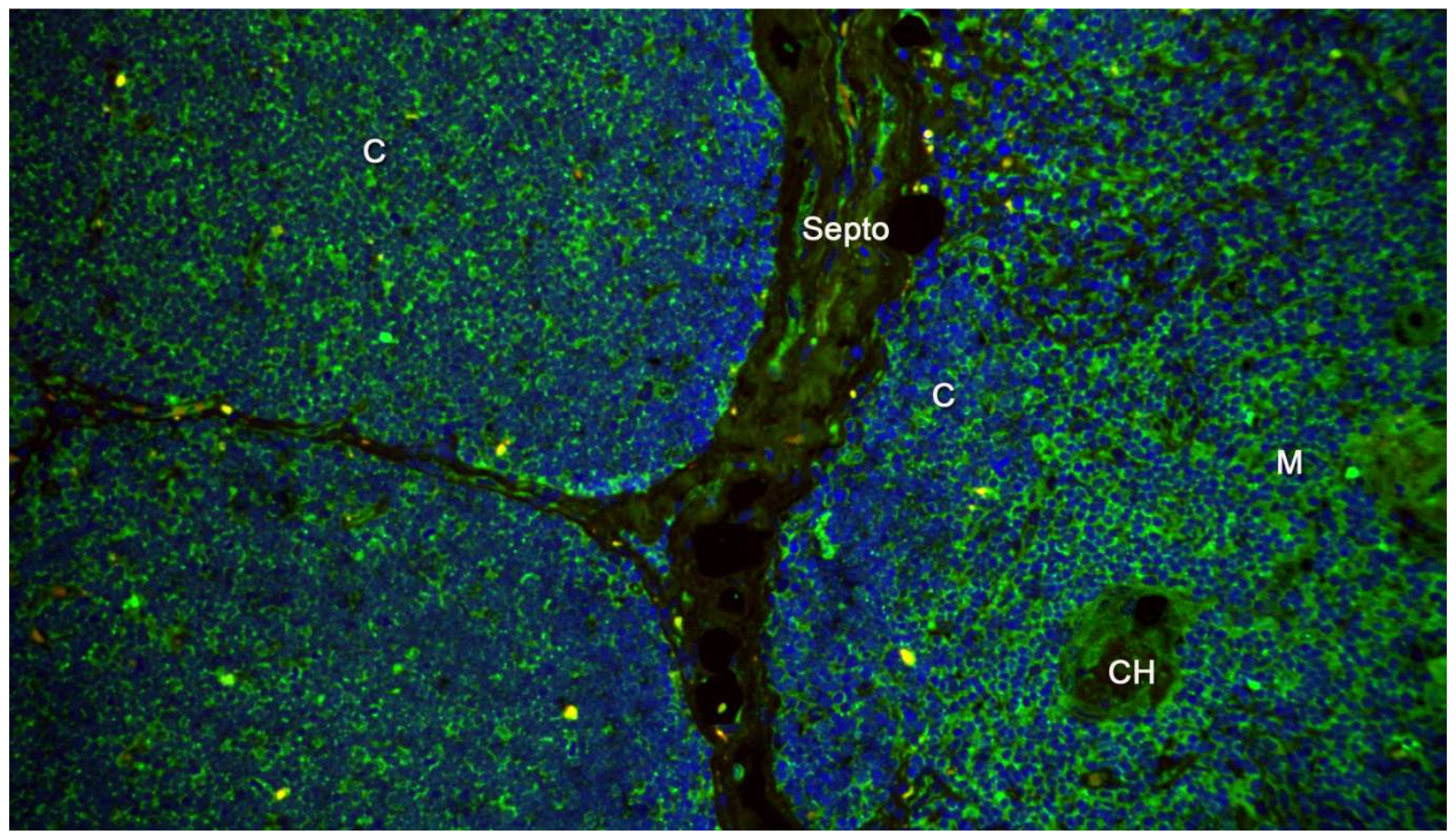

Figura 31. Imunofluorescência (FITC) de tecido tímico incubado com anti-Jag1, evidenciado a marcação de células das regiões cortical e medular, e de CET que formam os corpúsculos de Hassall (CH). Aumento de 200x.

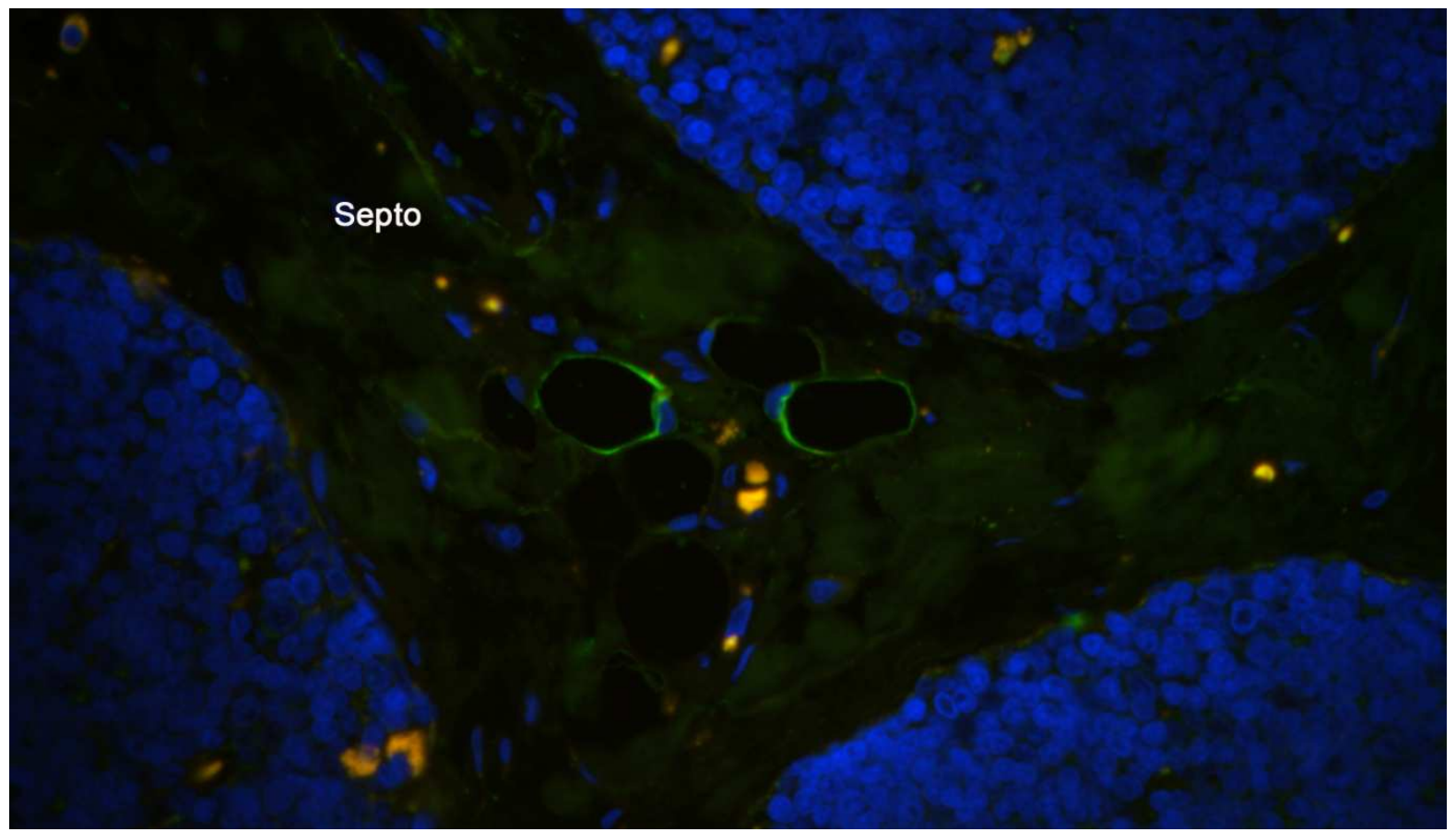

Figura 32. Imunofluorescência (FITC) de corte tímico tratado com anti-Jag2, evidenciado a marcação do endotélio de pequenos vasos localizados na região septal do timo. Aumento de 400x. 
Tabela 6 - Resumo da distribuição de receptores e ligantes Notch no timo humano.

\begin{tabular}{|c|c|c|c|c|c|c|c|c|c|c|c|c|}
\hline & \multicolumn{3}{|c|}{ Timócitos } & \multicolumn{5}{|c|}{ Epitélio } & \multicolumn{2}{|c|}{ Endotélio } & \multirow{2}{*}{ Dendrit } & \multirow{2}{*}{ Macrof } \\
\hline & Córtex & Medula & Subcap & Córtex & Medula & Subcap & Perivasc & Hassall & Septal & Cor-Med & & \\
\hline Notch 1 & +++ & +++ & ++ & ++ & +++ & +++ & ++ & ++ & +++ & +++ & + & ++ \\
\hline Notch 2 & - & - & - & - & +++ & +++ & +++ & ++ & - & - & - & - \\
\hline Notch 3 & - & Raras + & - & - & - & - & - & +++ & - & - & - & - \\
\hline Notch 4 & + & + & + & - & - & - & - & + & - & - & - & - \\
\hline $\operatorname{Jag} 1$ & ++ & +++ & ++ & ++ & +++ & ++ & ++ & +++ & - & - & ++ & ++ \\
\hline Jag 2 & - & - & - & - & - & - & - & - & Raras ++ & - & - & - \\
\hline Delta 1 & + & - & + & + & + & + & - & + & - & - & + & - \\
\hline Delta 4 & ++ & +++ & ++ & +++ & +++ & ++ & + & +++ & +++ & +++ & ++ & ++ \\
\hline
\end{tabular}

Dendrit = Células dendríticas; Macrof = Macrófagos; Subcap = subcapsular; Perivasc = perivascular; Cor-Med = córtico-medular.

- sem evidência de marcação

+ marcação leve

++ marcação intermediária

+++ marcação acentuada 


\subsection{Discussão}

O estudo da via de sinalização Notch é um campo recente e, dada a sua importância como um regulador essencial para a homeostasia da diferenciação, sobrevivência, direcionamento e desenvolvimento de células-tronco embrionárias, células-tronco hematopoiéticas e linhagens celulares derivadas, está em franco crescimento. Os mecanismos de interações, distribuição, ação e regulação dos sinais Notch são ainda pouco conhecidos.

Com o objetivo de caracterizar a localização e o tipo celular capaz de expressar cada ligante e receptor Notch no timo humano, dez espécimes tímicos, provenientes de crianças com cardiopatias congênitas submetidas a cirurgias cardíacas (Tabela 4), foram estudados por imunohistoquímica. Dentre os timos estudados, três foram doados por pacientes portadores da síndrome de Down (grupo SD).

Todos os espécimes tímicos foram avaliados por marcações simples utilizando-se os antissoros específicos para cada ligante e receptor Notch (Tabela 5). Os resultados mostram um padrão semelhante de expressão de Notch entre todos os timos estudados, em ambos os grupos - controle e SD.

Para identificar o tipo celular capaz de expressar Notch, quatro timos foram submetidos a marcações duplas utilizando-se antissoros específicos (Tabela 5) para o reconhecimento de proteínas caracteristicamente expressas por células dendríticas (S100), macrófagos (CD68) e células epiteliais (citoqueratina). Após os ensaios, foi possível identificar e descrever o tipo celular apresentando cada Notch.

Ao microscópio, observamos a marcação da maioria das células intratímicas com o anti-N1 (Figura 26). Alguns estudos demonstraram, em timos de modelos murinos, o bloqueio total do desenvolvimento de linfócitos $T$ após a inativação do $\mathrm{N} 1$, indicando que nenhum outro receptor da família Notch é capaz de compensar a sua falta (Radtke et al., 1999; Maillard et al., 2005). Além de células epiteliais, endoteliais, dendríticas e macrófagos, vimos que timócitos corticais e medulares recebem sinais $\mathrm{N} 1$, confirmando que esta molécula está envolvida no desenvolvimento de linfócitos T no timo humano. Além disto, sabe-se que N1 exerce funções de autorrenovação de células-tronco progenitoras intratímicas em 
camundongos (Maillard et al., 2005). Nós observamos uma acentuada marcação de N1 no citoplasma e na membrana de grupos de células apresentando uma clara colocalização de N1 e CD117 (Figura 27), confirmando que se trata de células progenitoras hematopoiéticas recém chegadas ao timo. Os nossos achados reforçam a ideia de que os sinais $\mathrm{N} 1$ são importantes para a autorrenovação de CTH, bem como para o comprometimento e a diferenciação de célula $T$ no timo humano.

Observamos a expressão de N2 apenas em células epiteliais específicas, as CET tipo I, que cercam toda a região subcapsular, subseptal e região perivascular dos vasos córtico-medulares (Figura 28). As CET tipo VI de alguns corpúsculos de Hassall também apareceram marcadas. De fato, alguns autores demonstraram, em modelos murinos, o envolvimento do receptor $\mathrm{N} 2$ no comprometimento e desenvolvimento de linfócitos B (Saito et al., 2003; Maillard et al., 2005), assim, os nossos resultados evidenciando a ausência de N2 em timócitos são coerentes com informações prévias sobre o papel de N2 na linfopoiese. Entretanto, até o memento, nada está descrito sobre a presença ou o possível papel de N2 em células epiteliais do timo.

Em relação ao receptor N3, alguns estudos descreveram, em modelo murino, que esta molécula tem um padrão de expressão semelhante ao N1 nos timócitos em desenvolvimento (Saito et al., 2003). Sabe-se também que N3 é amplamente expresso em timócitos nos estágios DN2 até DN4 e tem um papel fundamental na diferenciação e controle do crescimento celular (Bellavia et al., 2003). Como um fraco ativador transcricional, N3 atuaria como repressor de N1 por competir pelo sítio de ligação nos genes alvo (De La Coste et al., 2006). Entretanto, no timo humano, encontramos o receptor N3, predominantemente, no citoplasma e membrana de CET tipo VI na maioria dos corpúsculos de Hassall (Figura 29) e em raros timócitos medulares. Estes achados sugerem que N3 tem papeis distintos na timopoiese de camundongos e humanos.

Os nossos resultados mostraram uma marcação muito tênue de N4 nas CET dos corpúsculos de Hassall e nos timócitos corticais e medulares. Estes dados condizem com os achados de Saito et al. (2003), que observaram uma expressão muito pobre de N4 em timócitos de camundongos. Por outro lado, a marcação que 
observamos pode ser uma reação inespecífica, caracterizada pela ausência total de células apresentando uma marcação realçada.

Entre os ligantes Notch, o Jag1 se destacou por estar marcado em quase todas as células intratímicas, com diferenças apenas na acentuação da marcação (Figura 31). Timócitos, células dendríticas e macrófagos se mostraram bem marcados, enquanto as células epiteliais da região medular e dos corpúsculos de Hassall apareceram fortemente marcadas. Este ligante não foi visualizado no endotélio dos vasos intratímicos. Curiosamente, Jaleco et al. (2001) observaram que o ligante Jag1 parece não interferir no desenvolvimento linfoide a partir de célulastronco de cordão umbilical humano. Em timos de camundongos, a expressão de Jag1 foi descrita apenas em células do estroma (Felii et al., 1999); e a indução de expressão deste ligante em timócitos parece promover a apoptose, com consequente involução do estroma tímico, diminuição do número de timócitos e do órgão (Beverly et al., 2003).

Em nosso estudo, observamos o ligante Jag2 expresso apenas em células endoteliais de raros vasos da região saptal, com ausência de células, como hemácias, no seu interior (Figura 32). Em camundongos, o ligante Jag2 foi observado distribuído em timócitos e no estroma tímico (Felii et al., 1999), e a mutação no gene Jag2 promove uma discreta diminuição do número de células $T$ da linhagem $\gamma \delta$, além da morfologia tímica alterada (Jiang et al., 1998).

O principal papel atribuído ao ligante Dll1, na timopoiese, é o comprometimento de células hematopoiéticas indiferenciadas em linhagem $\mathrm{T}$ e $\mathrm{O}$ completo bloqueio da diferenciação em linhagem B (Jaleco et al., 2001). Por outro lado, a inativação deste ligante não bloqueia o desenvolvimento de células $T$, sugerindo um papel redundante entre Dll1 e outro ligante Notch, como o Dll4 (Maillard et al., 2005). Em camundongo, o Dll1 é amplamente expresso no estroma tímico, em particular na região córtico-medular (Schmitt et al., 2004), onde as células-tronco hematopoiéticas multipotentes recebem os primeiros sinais Notch após sua chegada no ambiente tímico. Entretanto, em nosso estudo, observamos apenas uma leve marcação de timócitos e células estromais em todas as regiões do timo. Algumas características da marcação observada, como a ausência de células 
bem marcadas, podem representar uma reação inespecífica do anti-DIl1 com o tecido tímico.

O endotélio de vasos córtico-medulares e septais, as células epiteliais e timócitos de todas as regiões do timo humano apresentaram uma acentuada expressão do ligante DII4. Células dendríticas e macrófagos também apareceram bem marcados. O padrão de expressão do Dll4, amplamente distribuído nas regiões cortical e medular do timo (Figura 30), se mostrou semelhante ao encontrado nos timos marcados com o anti-Jag1, diferindo apenas na marcação do endotélio, onde Jag1 está ausente. No timo de camundongos, o ligante Dll4 é caracteristicamente expresso nas células endoteliais e, recentemente, Hozumi et al. (2008) descreveram a expressão desta molécula em células epiteliais, especialmente naquelas localizadas na região cortical. A principal função atribuída ao ligante DII4, na timopoiese, se refere à ativação do receptor N1 expresso na superfície de células indiferenciadas multipotentes, fazendo com que estas células percam o potencial de se tornarem células B e se comprometam a originar apenas linfócitos T (Koch et al., 2008).

Os ligantes DIl4 e Jag1 se mostraram amplamente expressos em timócitos e células do estroma tímico. Entretanto, a origem da expressão destes ligantes não pode ser confirmada através da pesquisa de proteína por imunohistoquímica, pois a transendocitose do ligante é um fenômeno necessário para a regulação da sinalização Notch (Le Borgne, 2006; Fortini e Bilder, 2009), assim, a proteína detectada pode ter sido expressa por uma célula e aparecer marcada também na célula adjacente que está recebendo o sinal Notch.

Há grandes perspectivas acerca de novos achados que darão subsídio à expansão do conhecimento e suporte ao grande potencial de aplicabilidade experimental e terapêutica em várias áreas da Medicina (Embriologia, Imunologia, Neurologia, Oncologia, entre outras). A descrição da distribuição de ligantes e receptores Notch no timo humano representa mais um passo em direção à compreensão da dinâmica que rege a diferenciação de linfócitos $T$. 
CONCLUSÕES 


\section{CONCLUSÕES}

A investigação de moléculas importantes para o desenvolvimento (Notch) e seleção negativa (AIRE) de linfócitos $T$ no timo humano, proveniente de crianças com cardiopatias congênitas, algumas das quais com a síndrome de Down, nos permitiu concluir que:

1 - O receptor N1 é expresso abundantemente por células-tronco hematopoiéticas $\mathrm{CD}_{117^{+}}$, bem como por timócitos e células do estroma tímico das regiões cortical e medular. Esta molécula pode exercer um papel fundamental na autorrenovação de $\mathrm{CTH}$, bem como no comprometimento e diferenciação de célula T no timo humano.

2 - Os ligantes DII4 e Jag1 são amplamente expressos por timócitos e células do estroma tímico de ambas as regiões, cortical e medular, e podem estar diretamente envolvidos no desenvolvimento de linfócitos $T$.

3 - Os receptores N2 e N3 são expressos apenas por CET tipo II e CET tipo VI, respectivamente, sendo assim, não estariam diretamente relacionados à diferenciação de timócitos no timo humano.

4 - Aparentemente, o receptor N4 e os ligantes DIl1 e Jag2 não teriam um papel importante na diferenciação de timócitos em humanos, uma vez que apresentam expressão muito tênue.

5 - Timos de crianças com a SD apresentaram um número significativamente reduzido $(p<0.0001)$ de células epiteliais medulares expressando AIRE. As manifestações autoimunes frequentemente observadas na SD podem ser conseqüência da baixa expressão de AIRE nos portadores da trissomia. 


\section{REFERÊNCIAS*}

Aasland R, Gibson TJ, Stewart AF. The PHD finger: implications for chromatinmediated transcriptional regulation. Trends Biochem Sci. 1995;20:56-9.

Ahonen P, Myllarniemi S, Sipila I, Perheentupa J. Clinical variation of autoimmune polyendocrinopathy-candidiasis-ectodermal dystrophy (APECED) in a series of 68 patients. N Engl J Med. 1990;322:1829-36.

Amsen D, Antov A, Flavell RA. The different faces of Notch in T-helper-cell differentiation. Nat Rev Immunol. 2009;9:116-24.

Anderson MS, Venanzi ES, Chen Z, Berzins SP, Benoist C, Mathis D. The cellular mechanism of Aire control of T cell tolerance. Immunity. 2005;23:227-39.

Anderson MS, Venanzi ES, Klein L, Chen Z, Berzins SP, Turley SJ, et al. Projection of an immunological self shadow within the thymus by the aire protein. Science. 2002;298:1395-401.

Apostolou I, Sarukhan A, Klein L, von Boehmer H. Origin of regulatory T cells with known specificity for antigen. Nat Immunol. 2002;3:756-63.

Appay V, Sauce D, Prelog M. The role of the thymus in immunosenescence: lessons from the study of thymectomized individuals. Aging (Albany NY). 2010;2:78-81.

Aschenbrenner K, D'Cruz LM, Vollmann EH, Hinterberger M, Emmerich J, Swee LK, Rolink A, Klein L. Selection of Foxp3+ regulatory $T$ cells specific for self antigen expressed and presented by Aire+ medullary thymic epithelial cells. Nat Immunol. 2007;8:351-8.

Barrena M, Echaniz P, Garcia-Serrano C, Cuadrado E. Imbalance of the CD4+ subpopulations expressing CD45RA and CD29 antigens in the peripheral blood of adults and children with Down syndrome. Scand J Immunol. 1993;38:323-6.

Bellavia D, Campese AF, Vacca A, Gulino A, Screpanti I. Notch3, another Notch in T cell development. Semin Immunol. 2003;15:107-12. 
Betterle C, Greggio NA, Volpato M. Autoimmune polyglandular syndrome type 1. J Clin Endocrinol Metab. 1998;83:1049-55.

Beverly LJ, Ascano JM, Capobianco AJ. Expression of JAGGED1 in T-lymphocytes results in thymic involution by inducing apoptosis of thymic stromal epithelial cells. Genes Immun. 2006;7:476-86.

Billingham RE, Brent L, Medawar PB. Quantitative studies on tissue transplantation immunity. III. Actively acquired tolerance. Philos Trans R Soc Lond. 1956;239B:357412.

Botto L, May K, Fernhoff PM, Correa A, Coleman K, Rasmussen SA, et al. A population-based study of the $22 q 11.2$ deletion: phenotype, incidence, and contribution to major birth defects in the population. Pediatrics. 2003;112:101-7.

Bottomley MJ, Collard MW, Huggenvik JI, Liu Z, Gibson TJ, Sattler M. The SAND domain structure defines a novel DNA-binding fold in transcriptional regulation. Nat Struct Biol. 2001;8:626-33.

Chistiakov D. Down syndrome and coexistent autoimmune diseases. J Appl Biomed. 2007;5:71-76.

Ciofani M, Zúñiga-Pflücker JC. A Survival Guide to Early T Cell Development. Immunol Res. 2006;34:117-32.

Cooper MD, Alder MN. The Evolution of Adaptive Immune Systems. Cell. 2006;124:815-22.

Cordier AC, Haumont SM. Development of thymus, parathyroids, and ultimobranchial bodies in NMRI and Nude mice. Am J Anat. 1980;157:227-63.

Cordier AC, Heremans JF. Nude mouse embryo: ectodermal nature of the primordial thymic defect. Scand J Immunol. 1975;4:193-6.

De La Coste A, Freitas AA. Notch signaling: Distinct ligands induce specific signals during lymphocyte development and maturation. Immunol Lett. 2006;112:1-9. 
Felli MP, Maroder M, Mitsiadis TA, Campese AF, Bellavia D, Vacca A, et al. Expression pattern of notch1, 2 and 3 and Jagged 1 and 2 in lymphoid and stromal thymus components: distinct ligand-receptor interactions in intrathymic $\mathrm{T}$ cell development. Int Immunol. 1999;11:1017-25.

Ferguson BJ, Alexander C, Rossi SW, Liiv I, Rebane A, Worth CL, et al. AIRE's CARD revealed, a new structure for central tolerance provokes transcriptional plasticity. J Biol Chem. 2008;283:1723-31.

Finnish-German APECED Consortium. An autoimmune disease, APECED, caused by mutations in a novel gene featuring two PHD-type zinc-finger domains. Nature Genet. 1997;17:399-403.

Fiuza UM, Arias AM. Cell and molecular biology of Notch. J Endocrinol. 2007;94:459-74.

Fortini ME, Bilder D. Endocytic regulation of Notch signaling. Curr Opin Genet Dev. 2009;19:323-8.

Gill J, Malin M, Sutherland J, Gray D, Hollander G, Boyd R. Thymic generation and regeneration. Immunol Rev. 2003;195:28-50.

Glick B, Chang TS, Japp RG. The bursa of Fabricius and antibody production. Poultry Sci. 1956;35:224-5.

Godfrey DI, Kennedy J, Suda T, Zlotnik A. A developmental pathway involving four phenotypically and functionally distinct subsets of CD3-CD4-CD8-triple-negative adult mouse thymocytes defined by CD44 and CD25 expression. J Immunol. 1993;150:4244-52.

Gordon J, Wilson VA, Blair NF, Sheridan J, Farley A, Wilson L, et al. Functional evidence for a single endodermal origin for the thymic epithelium. Nat Immunol. 2004;5:546-53.

Gotter J, Brors B, Hergenhahn M, Kyewski B.Medullary epithelial cells of the human thymus express a highly diverse selection of tissue-specific genes colocalized in chromosomal clusters. J Exp Med. 2004;199:155-66. 
Gowans IL, Gesner BM, McGregor DD. The immunological activities of lymphocytes. In: Wolstenholme GEW, O'Connor M, eds. Biological activity of leucocyte. Ciba Foundation Study Group. London: Churchill. 1961;32-34.

Guidos CJ. Notch signaling in lymphocyte development. Semin Immunol. 2002;14:395-404.

Hale LP. Histologic and Molecular Assessment of Human Thymus. Ann Diagn Pathol. 2004;8:50-60.

Harper JA, Yuan JS, Tan JB, Visan I, Guidos CJ. Notch signaling in development and disease. Clin Genet. 2003;64:461-72.

Haynes BF, Sempowski GD, Wells AF, Hale LP. The human thymus during aging. Immunol Res. 2000;22:253-61.

Heino M, Peterson P, Kudoh J, Nagamine K, Lagerstedt A, Ovod V, et al. Autoimmune regulator is expressed in the cells regulating immune tolerance in thymus medulla. Biochem Biophys Res Commun. 1999;257:821-5.

Hoffman JI, Kaplan S. The incidence of congenital heart disease. J Am Coll Cardiol. 2002;39:1890-1900.

Hozumi K, Mailhos C, Negishi N, Hirano K, Yahata T, Ando K, Zuklys S, Holländer GA, Shima DT, Habu S. Delta-like 4 is indispensable in thymic environment specific for T cell development. J Exp Med. 2008;205:2507-13.

Hudson LL, Louise Markert M, Devlin BH, Haynes BF, Sempowski GD. Human T cell reconstitution in DiGeorge syndrome and HIV-1 infection. Semin Immunol. 2007;19:297-309.

Husebye ES, Kappler JW, Marrack P. Thymic selection stifles TCR reactivity with the main chain structure of $\mathrm{MHC}$ and forces interactions with the peptide side chains. Mol Immunol. 2008;45:599-606.

Husebye ES, Perheentupa J, Rautemaa R, Kämpe O. Clinical manifestations and management of patients with autoimmune polyendocrine syndrome type I. J Intern Med. 2009;265:514-29. 
Jaleco AC, Neves H, Hooijberg E, Gameiro P, Clode N, Haury M, et al. Differential effects of Notch ligands Delta-1 and Jagged-1 in human lymphoid differentiation. J Exp Med. 2001;194:991-1002.

Jawad AF, McDonald-McGinn DM, Zackai E, Sullivan K. Immunologic features of chromosome 22q11.2 deletion syndrome (DiGeorge and velocardiofacial syndromes). J Pediatr. 2001;139:715-23.

Jiang R, Lan Y, Chapman HD, Shawber C, Norton CR, Serreze DV, et al. Defects in limb, craniofacial, and thymic development in Jagged2 mutant mice. Genes Dev. 1998;12:1046-57.

Jordan MS, Boesteanu A, Reed AJ, Petrone AL, Holenbeck AE, Lerman MA, et al. Thymic selection of CD4+CD25+ regulatory $T$ cells induced by an agonist selfpeptide. Nat Immunol. 2001;2:283-4.

Kappes DJ, He X, He X. CD4-CD8 lineage commitment: an inside view. Nat Immunol. 2005;6:761-7.

Karlsson B, Gustafsson J, Hedov G, Ivarsson S-A, Annerén G. Thyroid dysfunction in Down's syndrome: relation to age and thyroid autoimmunity. Arch. Dis Child. 1998;79:242-5.

Kekalainen E, Tuovinen $\mathrm{H}$, Joensuu J, Gylling M, Franssila R, Pöntynen N, et al. A defect of regulatory $T$ cells in patients with autoimmune polyendocrinopathycandidiasis-ectodermal dystrophy. J Immunol. 2007;178:1208-15.

Klamp T, Sahin U, Kyewski B, Schwendemann J, Dhaene K, Türeci O. Expression profiling of autoimmune regulator AIRE mRNA in a comprehensive set of human normal and neoplastic tissues. Immunol Lett. 2006;106:172-9.

Koch U, Fiorini E, Benedito R, Besseyrias V, Schuster-Gossler K, Pierres M, et al. Delta-like 4 is the essential, nonredundant ligand for Notch1 during thymic $\mathrm{T}$ cell lineage commitment. J Exp Med. 2008;205:2515-23.

Kohlhaas S, Garden OA, Scudamore C, Turner M, Okkenhaug K, Vigorito E. Cutting Edge: The Foxp3 Target miR-155 Contributes to the Development of Regulatory T Cells. J Immunol. 2009;182:2578-82. 
Kuhn DE, Nuovo GJ, Martin MM, Malana GE, Pleister AP, Jiang J, et al. Human Chromosome 21-derived miRNAs are Over-expressed in Down Syndrome Brains and Hearts. Biochem Biophys Res Commun. 2008;370:473-7.

Ladi E, Nichols JT, Ge W, Miyamoto A, Yao C, Yang LT, et al. The divergent DSL ligand DII3 does not activate Notch signaling but cell autonomously attenuates signaling induced by other DSL ligands. J Cell Biol. 2005;170:983-92.

Larocca LM, Lauriola L, Ranelletti FO, Piantelli M, Maggiano N, Ricci R, Capelli A. Morphological and immunohistochemical study of Down syndrome thymus. Am J Med Genet Suppl. 1990;7:225-30.

Le Borgne $R$, Bardin A, Schweisguth $F$. The roles of receptor and ligand endocytosis in regulating Notch Signaling. Development. 2005;132:1751-62.

Le Borgne R. Regulation of Notch signalling by endocytosis and endosomal sorting. Curr. Opin. Cell Biol. 2006;18:213-22.

Levelt CN, Carsetti R, Eichmann K. Regulation of thymocyte development through CD3. II. Expression of T cell receptor $\beta$ CD3 $\varepsilon$ and maturation to the CD4+8+ stage are highly correlated in individual thymocytes. J Exp Med. 1993a;6:1867-75.

Levelt CN, Ehrfeld A, Eichmann K. Regulation of thymocyte development through CD3. I. Timepoint of ligation of CD3 $\varepsilon$ determines clonal deletion or induction of developmental program. J Exp Med. 1993b;177:707-16.

Liston A, Gray DH, Lesage S, Fletcher AL, Wilson J, Webster KE, et al. Gene dosage-limiting role of Aire in thymic expression, clonal deletion, and organ-specific autoimmunity. J Exp Med. 2004;200:1015-26.

Liston A, Lesage S, Wilson J, Peltonen L, Goodnow CC. Aire regulates negative selection of organ-specific T cells. Nat Immunol. 2003;4:350-4.

Litman GW, Cannon JP, Dishaw LJ. Reconstructing immune phylogeny: new perspectives. Nat Rev Immunol. 2005;5:866-79.

Lynch HE, Goldberg GL, Chidgey A, Van den Brink MRM, Boyd R, Sempowski GD. Thymic involution and immune reconstitution. Trends Immunol. 2009;30:366-73. 
Maillard I, Fang T, Pear WS. Regulation of Lymphoid Development, Differentiation, and Function by the Notch Pathway. Annu Rev Immunol. 2005;23:945-74.

Manley NR, Blackburn CC. A developmental look at thymus organogenesis: where do the non-hematopoietic cells in the thymus come from? Curr Opin Immunol. 2003,15:225-32.

Markert ML, Devlin BH, McCarthy EA. Thymus transplantation. Clin Immunl. 2010;135:236-46.

Markert ML, Kostyu DD, Ward FE, McLaughlin TM, Watson TJ, Buckley RH, et al. Successful formation of a chimeric human thymus allograft following transplantation of cultured postnatal human thymus. Journal of Immunology. 1997;158:998-1005.

Mathis D, Benoist C. A decade of AIRE. Nat Rev Immunol. 2007;7:645-50.

Mathis D, Benoist C. AIRE. Annu Rev Immunol. 2009;27:287-312.

Miller JFAP. Immunological function of the thymus. Lancet. 1961;ii:748-9.

Murphy M, Epstein L. Down syndrome peripheral blood contains phenotypically mature CD3 TCRalphabeta cells but abnormal proportions of TCRgammadelta, TCRalphabeta and CD4+45RA+ cells: evidence for an inefficient release of mature $T$ cells by DS thymus. Clin Immunol Immunopathol. 1992a;62:245-51.

Murphy M, Friend D, Pike-Nobile L Epstein LB. Tumor necrosis factoralpha and IFNgamma expression in human thymus. J Immunol. 1992b;149:2506-12.

Murphy M, Insoft RM, Pike-Nobile L, Epstein LB. A hypothesis to explain the immune defects in Down syndrome. Prog Clin Biol Res. 1995;393:147-67.

Murphy M, Lempert M, Epstein L. Decreased level of $\mathrm{T}$ cell receptor expression by Down syndrome (trisomy 21) thymocytes. Am J Med Genet. 1990;7:234-7.

Murumagi A, Vahamurto P, Peterson P. Characterization of Regulatory Elements and Methylation Pattern of the Autoimmune Regulator (AIRE) Promoter. J Biol Chem. 2003;278:19784-90. 
Nagamine K, Peterson P, Scott HS, Kudoh J, Minoshima S, Heino M, et al. Positional cloning of the APECED gene. Nat Genet. 1997;17:393-8.

Ng WF, Duggan FJ, Ponchel F, Matarese G, Lombardi G, Edwards AD, et al. Human CD41CD251 cells: a naturally occurring population of regulatory T cells. Immunology. 2001;98:2736-44.

Nishino M, Ashiku SK, Kocher ON, Thurer RL, Boiselle PM, Hatabu H. The thymus: a comprehensive review. Radiographics. 2006;26:335-48.

Oettinger MA, Schatz DG, Gorka C, Baltimore D. RAG-1 and RAG-2, adjacent genes that synergistically activate $V(D) J$ recombination. Science. 1990;248:1517-23.

Org T, Chignola F, Hetényi C, Gaetani M, Rebane A, Liiv I, et al. The autoimmune regulator PHD finger binds to non-methylated histone $\mathrm{H} 3 \mathrm{~K} 4$ to activate gene expression. EMBO Rep. 2008;9:370-6.

Öskarsdóttir S, Vujic M, Fasth A. Incidence and prevalence of the $22 q 11$ deletion syndrome: a population-based study in Western Sweden. Arch Dis Child. $2004 ; 89: 148-51$.

Owen JJ, McLoughlin DE, Suniara RK, Jenkinson EJ. The role of mesenchyme in thymus development. Curr Top Microbiol Immunol. 2000;251:133-7.

Perheentupa J. Autoimmune polyendocrinopathy-candidiasis-ectodermal dystrophy. J Clin Endocrinol Metab. 2006;91:2843-50.

Peterson P, Nagamine K, Scott H, Heino M, Kudoh J, Shimizu N, et al. APECED: a monogenic autoimmune disease providing new clues to self-tolerance. Immunol Today. 1998;19:384-6.

Plum J, De Smedt M, Leclercq G, Taghon T, Kerre T, Vandekerckhove B. Human intrathymic development: a selective approach. Semin Immunopathol. 2008;30:41123.

Powell BR, Buist NRM, Stenzel P. An X-linked syndrome of diarrhea polyendocrinopathy, and fatal infection in infancy. J Pediatr. 1982;100:731-7. 
Radtke F, Fasnacht N, MacDonald HR. Notch Signaling in the Immune System. Immunity. 2010;32:14-27.

Radtke F, Wilson A, Mancini SJ, MacDonald HR. Notch regulation of lymphocyte development and function. Nat Immunol. 2004;5:247-53.

Radtke F, Wilson A, Stark G, Bauer M, Van Meerwijk J, MacDonald HR, Aguet M. Deficient $T$ cell fate specification in mice whit an induced inactivation of Notch1. Immunity. 1999;10:547-58.

Raica M, Encica S, Motoc A, Cîmpean AM, Scridon T, Bârsan M. Structural heterogeneity and immunohistochemical profile of Hassall corpuscles in normal human thymus. Ann Anat. 2006;188:345-52.

Rezzani R, Bonomini F, Rodella LF. Histochemical and molecular overview of the thymus as site for T-cells development. Prog Histochem Cytochem. 2008;43:73120.

Rizzi M, Ferrera F, Filaci G, Indiveri F. Disruption of immunological tolerance: Role of AIRE gene in autoimmunity. Autoimmun Rev. 2006;5:145-7.

Robey E, Chang D, Itano A, Cado D, Alexander H, Lans D, et al. An activated form of Notch influences the choice between CD4 and CD8 $T$ cell lineages. Cell. 1996;87:483-92.

Rodewald HR. Thymus organogenesis. Annu Rev Immunol. 2008;26:355-88.

Rubinstein A, Pelet B, Schweizer V. Immunological decay in thymectomized infants. Helv Paediatr Acta. 1976;30:425-33.

Ryan AK, Goodship JA, Wilson DI, Philip N, Levy A, Seidel H, et al. Spectrum of clinical features associated with interstitial chromosome 22q11 deletions: a European collaborative study. J Med Genet. 1997;34:798-804.

Saito T, Chiba S, Ichikawa M, Kunisato A, Asai T, Shimisu K, et al. Notch2 is preferentially expressed in mature $B$ cells and indispensable for marginal zone $B$ lineage development. Immunity. 2003;18:675-85. 
Sauce D, Larsen M, Fastenackels S, Duperrier A, Keller M, Grubeck-Loebenstein B, et al. Evidence of premature immune aging in patients thymectomized during early childhood. J Clin Invest. 2009;119:3070-8.

Schmitt TM, Ciofani M, Petrie HT, Zúñiga-Pflücker JC. Maintenance of $T$ cell specification and differentiation requires recurrent notch receptor-ligand interactions. J Exp Med. 2004;200:469-79.

Schuurman HJ, Kuper CF, Kendall MD. Thymic microenvironment at the light microscopic level. Microsc Res Tech. 1997;38:216-26.

Södrerbergh A, Gustafsson J, Ekwall O, Hallgren A, Nilsson T, Kämpe O, et al. Autoantibodies linked to autoimmune polyendocrine syndrome type I are prevalent in Down syndrome. Acta Paediatr. 2006;95:1657-60.

Steinmann GG, Klaus B, Müller-Hermelink HK. The involution of the ageing human thymic epithelium is independent of puberty. A morphometric study. Scand J Immunol. 1985;22:563-75.

Sullivan KE. The clinical, immunological, and molecular spectrum of chromosome 22q11.2 deletion syndrome and DiGeorge syndrome. Curr Opin Allergy Clin Immunol. 2004;4:505-12.

Takahama Y. Journey through the thymus: stromal guides for T-cell development and selection. Nat Rev Immunol. 2006;6:127-35.

Tanigaki K, Honjo T. Regulation of lymphocyte development by Notch signaling. Nat immunol. 2007;8:451-6.

Taubert R, Schwendemann J, Kyewski B. Highly variable expression of tissuerestricted self-antigens in human thymus: implications for self-tolerance and autoimmunity. Eur J Immunol. 2007;37:838-48.

Tien AC, Rajan A, Bellen HJ. A Notch updated. J Cell Biol. 2009;184:621-9.

Uchida D, Hatakeyama S, Matsushima A, Han $H$, Ishido $S$, Hotta $H$, et al. AIRE functions as an E3 ubiquitin ligase. J Exp Med. 2004;199:167-72. 
Utiyama SRR, Nisihara RM, Nass FR, Oliveira NP, Fiedler PT, Messias-Reason IT. Autoantibodies in patients with Down Syndrome: Early senescence of the immune system or precocious markers for immunological diseases? J Paediatr Child Health. 2008;44:182-6.

van der Vliet HJJ, Nieuwenhuis EE. Clin Dev Immuno. 2007;2007:89017.

van de Wijngaert FP, Kendall MD, Schuurman HJ, Rademakers LH, Kater L. Heterogeneity of epithelial cells in the human thymus. An ultrastructural study. Cell Tissue Res. 1984;237:227-37.

von Gaudecker B. Functional histology of the human thymus. Anat Embryol (Berl). 1991;183:1-15.

Wang J, Xing F. Human TSLP-educated DCs. Cell Mol Immunol. 2008;5:99-106.

Washburn T, Schweighoffer E, Gridley T, Chang D, Fowlkes BJ, Cado D, et al. Notch activity influences the $\alpha \beta$ versus $\gamma \delta$ T cell lineage decision. Cell. 1997;88:833-43.

Watanabe N, Wang $\mathrm{YH}$, Lee HK, Ito T, Wang YH, Cao W, Liu YJ. Hassall's corpuscles instruct dendritic cells to induce CD4+CD25+ regulatory $T$ cells in human thymus. Nature. 2005;436:1181-5.

Wolfer A, Wilson A, Nemir M, MacDonald HR, Radtke F. Inactivation of Notch1 impairs VDJ $\beta$ rearrangement and allows pre-TCR-independent survival of early $\alpha \beta$ lineage thymocytes. Immunity. 2002;16:869-79.

Yahya-Graison EA, Aubert J, Dauphinot L, Rivals I, Prieur M, Golfier G, et al. Classification of human chromosome 21 gene-expression variations in Down syndrome: Impact on disease phenotypes. Am J Hum Genet. 2007;81:475-91.

Yamada $Y$, Watanabe $H$, Miura $F$, Soejima $H$, Uchiyama $M$, Iwasaka $T$, et al. A Comprehensive Analysis of Allelic Methylation Status of $\mathrm{CpG}$ Islands on Human Chromosome 21q. Genome Res. 2004;14:247-66.

Zhou L, Seo KH, Wong HK, Mi QS. MicroRNAs and immune regulatory T cells. Int Immunopharmacol. 2009;9:524-7. 
Zlamy M, Prelog M. Thymectomy in early childhood: a model for premature T cell immunosenescence? Rejuvenation Res. 2009;12:249-58.

Zuklys S, Balciunaite G, Agarwal A, Fasler-Kan E, Palmer E, Hollander GA. Normal thymic architecture and negative selection are associated with Aire expression, the gene defective in the autoimmunepolyendocrinopathy-candidiasis-ectodermal dystrophy (APECED). J Immunol. 2000;165:1976-83 
ANEXOS 
ANEXO A - Modelo do termo de consentimento

\section{TERMO DE CONSENTIMENTO}

I - DADOS DE IDENTIFICAÇÃO DO SUJEITO DA PESQUISA

NOME DO PACIENTE:

DOC. DE IDENTIDADE № :

SEXO: MAS [ ] $\quad$ FEM [ ]

DATA DE NASCIMENTO:

$/ \ldots \ldots .$.

\section{DADOS DO RESPONSÁVEL LEGAL}

NOME COMPLETO:

PARENTESCO: DOC. DE IDENTIDADE № :

ENDEREÇO:

№

APTO:

BAIRRO:

CIDADE:

UF:

CEP:

TELEFONE: (......)

\section{II - REGISTRO DAS EXPLICAÇÕES DO PESQUISADOR AO RESPONSÁVEL LEGAL DO PACIENTE, SOBRE A PESQUISA CIENTÍFICA QUE SERÁ DESENVOLVIDA}

\section{Justificativa e objetivos da pesquisa}

O timo é um dos órgãos responsáveis pelo desenvolvimento de células de defesa do organismo. Durante a cirurgia cardíaca de crianças, o timo é normalmente retirado para facilitar a visualização e o manuseio do coração e estruturas associadas. A retirada do timo é realizada rotineiramente em crianças nos primeiros anos de vida, pois nesta idade o timo é muito grande e está localizado à frente do coração, dificultando o acesso cirúrgico. O timo removido não é re-implantado, pois durante a cicatrização ocorre um grande processo de fibrose nesse órgão, o que dificulta o manuseio em caso de necessidade de nova cirurgia. $O$ timo retirado é então descartado. Entretanto, a utilização deste órgão, para fins de pesquisa, pode ajudar no entendimento de algumas funções do sistema imunológico, como a defesa do organismo contra bactérias, vírus, fungos e células cancerosas; e a prevenção de reações do próprio organismo contra ele mesmo.

Desta forma, é muito importante entender como as células de defesa se formam dentro do timo humano. 


\section{Procedimentos que serão utilizados, incluindo a identificação dos procedimentos experimentais}

O cirurgião removerá o timo, como de rotina, no momento da cirurgia de correção do coração ou estruturas associadas. O timo retirado será conservado e levado ao laboratório, onde será realizada a análise do órgão. Este estudo engloba uma análise histológica, e uma análise da expressão de proteínas responsáveis pelo funcionamento normal do timo.

Todos os timos serão identificados por um código e pelo número do IH do paciente. Os dados clínicos serão mantidos sob sigilo, em armário dedicado, trancado à chave.

\section{Desconfortos e riscos esperados}

Não há desconfortos ou riscos adicionais associados ao projeto, uma vez que o procedimento será feito necessariamente para acesso cirúrgico ao coração e/ou vasos da base do coração e não por necessidade experimental.

\section{Benefícios que poderão ser obtidos}

O principal benefício na participação deste projeto é permitir o avanço do conhecimento científico sobre o funcionamento do sistema imune que poderá, no futuro, beneficiar e até salvar a vida de outras pessoas.

\section{III - CONSENTIMENTO PÓS-ESCLARECIMENTO}

Declaro que, após todos os esclarecimentos sobre a pesquisa, apresentados pelo pesquisador responsável, entendi o que me foi explicado e ciente, concordo em doar o órgão (Timo) removido da criança de minha responsabilidade para fins de pesquisa científica.

São Paulo, de de 20 
ANEXO B.1 - Contagens de células epiteliais $\mathrm{AlRE}^{+}$, por campo, na medula tímica de 46 timos humanos.

\begin{tabular}{|c|c|c|c|c|c|c|c|c|c|}
\hline \multirow{2}{*}{ Registro } & \multicolumn{9}{|c|}{ Células AIRE ${ }^{+}$por campo } \\
\hline & 1 & 2 & 3 & 4 & 5 & 6 & 7 & 8 & 9 \\
\hline 3575012 & 4 & 12 & 3 & 4 & 2 & 4 & 3 & 4 & 6 \\
\hline 4199189 & 9 & 12 & 9 & 5 & 4 & 7 & 5 & 10 & 6 \\
\hline 3932834 & 14 & 7 & 17 & 5 & 10 & 13 & 8 & 10 & 15 \\
\hline 3233154 & 10 & 13 & 8 & 6 & 3 & 10 & 13 & 3 & 7 \\
\hline 3252060 & 13 & 7 & 15 & 6 & 8 & 9 & 16 & 18 & 18 \\
\hline 3888010 & 12 & 7 & 18 & 18 & 8 & 4 & 3 & 9 & 2 \\
\hline 3178781 & 11 & 5 & 11 & 10 & 2 & 8 & 6 & 7 & 2 \\
\hline 3331792 & 18 & 2 & 6 & 2 & 1 & 33 & 18 & 5 & 9 \\
\hline 3790169 & 4 & 4 & 1 & 3 & 4 & 5 & 2 & 1 & 3 \\
\hline 4427181 & 9 & 15 & 14 & 7 & 10 & 6 & 10 & 14 & 16 \\
\hline 3182274 & 16 & 19 & 5 & 23 & 10 & 14 & 13 & 22 & 7 \\
\hline 3587983 & 21 & 17 & 24 & 17 & 12 & 19 & 5 & 17 & 5 \\
\hline 4446518 & 14 & 16 & 12 & 17 & 19 & 15 & 12 & 17 & 14 \\
\hline 4664965 & 20 & 10 & 12 & 8 & 20 & 13 & 17 & 11 & 12 \\
\hline 4565118 & 10 & 5 & 6 & 8 & 9 & 4 & 12 & 10 & 5 \\
\hline 4263685 & 8 & 7 & 4 & 10 & 9 & 4 & 8 & 2 & 10 \\
\hline 3225755 & 7 & 8 & 2 & 22 & 6 & 10 & 24 & 10 & 8 \\
\hline 3012050 & 11 & 12 & 5 & 22 & 8 & 4 & 11 & 9 & 11 \\
\hline 2843757 & 14 & 11 & 10 & 17 & 17 & 15 & 10 & 17 & 22 \\
\hline 3013014 & 3 & 14 & 3 & 7 & 7 & 7 & 7 & 6 & 5 \\
\hline 2794640 & 1 & 0 & 1 & 7 & 9 & 4 & 7 & 0 & 2 \\
\hline 3162877 & 8 & 8 & 12 & 9 & 6 & 6 & 10 & 4 & 2 \\
\hline 3233855 & 17 & 20 & 9 & 28 & 6 & 24 & 30 & 23 & 9 \\
\hline 2995727 & 13 & 25 & 26 & 18 & 13 & 12 & 6 & 11 & 9 \\
\hline 3794083 & 13 & 15 & 16 & 12 & 10 & 15 & 8 & 15 & 18 \\
\hline 4592913 & 8 & 26 & 13 & 21 & 6 & 7 & 16 & 5 & 16 \\
\hline 4200764 & 10 & 7 & 4 & 14 & 8 & 6 & 5 & 8 & 5 \\
\hline 4059395 & 6 & 3 & 11 & 9 & 5 & 7 & 6 & 5 & 6 \\
\hline 3032434 & 14 & 14 & 29 & 12 & 12 & 12 & 21 & 17 & 13 \\
\hline 3971031 & 8 & 8 & 6 & 2 & 1 & 4 & 3 & 2 & 8 \\
\hline 3776549 & 6 & 8 & 6 & 10 & 7 & 7 & 5 & 0 & 3 \\
\hline 3223990 & 8 & 3 & 20 & 1 & 11 & 2 & 5 & 2 & 11 \\
\hline 3790452 & 7 & 13 & 6 & 15 & 6 & 6 & 6 & 6 & 10 \\
\hline 4200748 & 14 & 10 & 10 & 10 & 17 & 12 & 10 & 16 & 6 \\
\hline 3027643 & 8 & 14 & 22 & 7 & 8 & 5 & 10 & 14 & 9 \\
\hline 3975940 & 4 & 10 & 9 & 6 & 2 & 12 & 13 & 4 & 8 \\
\hline 3009793 & 23 & 7 & 7 & 17 & 5 & 13 & 6 & 2 & 4 \\
\hline
\end{tabular}


Contagens de células epiteliais $\mathrm{AIRE}^{+}$, por campo, na medula tímica de 46 timos humanos.

(conclusão)

\begin{tabular}{|r|r|r|r|r|r|r|r|r|r|}
\hline \multirow{2}{*}{ Registro } & \multicolumn{10}{|c|}{ Células AlRE+ por campo $^{+1}$} \\
\cline { 2 - 11 } & $\mathbf{1}$ & $\mathbf{2}$ & $\mathbf{3}$ & $\mathbf{4}$ & $\mathbf{5}$ & $\mathbf{6}$ & $\mathbf{7}$ & $\mathbf{8}$ & \multicolumn{1}{c|}{$\mathbf{9}$} \\
\hline 3393534 & 7 & 8 & 12 & 17 & 9 & 12 & 14 & 18 & 5 \\
\hline 3082849 & 16 & 20 & 7 & 9 & 15 & 12 & 13 & 5 & 15 \\
\hline 3213056 & 1 & 7 & 1 & 19 & 11 & 7 & 17 & 8 & 8 \\
\hline 2821826 & 7 & 11 & 4 & 11 & 7 & 10 & 5 & 11 & 7 \\
\hline 3177858 & 10 & 4 & 8 & 5 & 12 & 11 & 8 & 4 & 9 \\
\hline 2851008 & 11 & 6 & 6 & 20 & 5 & 13 & 12 & 8 & 11 \\
\hline 3175472 & 7 & 3 & 3 & 11 & 7 & 16 & 6 & 7 & 10 \\
\hline 4510135 & 18 & 10 & 19 & 12 & 31 & 26 & 27 & 18 & 13 \\
\hline 752240 & 16 & 3 & 9 & 3 & 6 & 4 & 4 & 7 & 7 \\
\hline
\end{tabular}


ANEXO B.2 - Contagens de timócitos Foxp3 ${ }^{+}$, por campo, na medula tímica de 46 timos humanos.

\begin{tabular}{|c|c|c|c|c|c|c|c|c|c|}
\hline \multirow{2}{*}{ Registro } & \multicolumn{9}{|c|}{ Células Foxp $3^{+}$por campo } \\
\hline & 1 & 2 & 3 & 4 & 5 & 6 & 7 & 8 & 9 \\
\hline 3575012 & 42 & 29 & 36 & 44 & 46 & 51 & 32 & 41 & 41 \\
\hline 4199189 & 49 & 66 & 38 & 40 & 48 & 42 & 57 & 67 & 58 \\
\hline 3932834 & 52 & 35 & 42 & 39 & 52 & 42 & 61 & 53 & 59 \\
\hline 3233154 & 58 & 35 & 51 & 64 & 37 & 57 & 48 & 60 & 44 \\
\hline 3252060 & 33 & 38 & 27 & 42 & 44 & 36 & 49 & 29 & 36 \\
\hline 3888010 & 62 & 74 & 55 & 31 & 48 & 34 & 49 & 48 & 53 \\
\hline 3178781 & 44 & 49 & 52 & 39 & 38 & 60 & 61 & 48 & 44 \\
\hline 3331792 & 28 & 23 & 27 & 27 & 22 & 36 & 33 & 16 & 49 \\
\hline 3790169 & 9 & 12 & 20 & 15 & 11 & 17 & 12 & 18 & 17 \\
\hline 4427181 & 56 & 58 & 70 & 58 & 61 & 55 & 83 & 58 & 79 \\
\hline 3182274 & 78 & 38 & 36 & 42 & 32 & 48 & 54 & 42 & 40 \\
\hline 3587983 & 25 & 22 & 24 & 23 & 19 & 26 & 36 & 34 & 29 \\
\hline 4446518 & 46 & 76 & 45 & 65 & 49 & 54 & 56 & 74 & 54 \\
\hline 4664965 & 55 & 45 & 46 & 35 & 41 & 42 & 34 & 45 & 62 \\
\hline 4565118 & 96 & 121 & 73 & 98 & 64 & 116 & 65 & 74 & 80 \\
\hline 4263685 & 72 & 62 & 35 & 47 & 90 & 74 & 72 & 57 & 57 \\
\hline 3225755 & 63 & 49 & 70 & 71 & 61 & 48 & 38 & 59 & 61 \\
\hline 3012050 & 81 & 85 & 78 & 64 & 52 & 78 & 54 & 62 & 49 \\
\hline 2843757 & 32 & 31 & 31 & 26 & 17 & 18 & 24 & 27 & 23 \\
\hline 3013014 & 32 & 41 & 19 & 28 & 38 & 36 & 37 & 49 & 41 \\
\hline 2794640 & 30 & 46 & 57 & 42 & 31 & 34 & 41 & 59 & 40 \\
\hline 3162877 & 45 & 60 & 42 & 47 & 59 & 43 & 31 & 44 & 32 \\
\hline 3233855 & 65 & 62 & 61 & 87 & 61 & 68 & 98 & 46 & 77 \\
\hline 2995727 & 26 & 28 & 35 & 37 & 38 & 27 & 41 & 29 & 31 \\
\hline 3794083 & 33 & 69 & 52 & 55 & 42 & 41 & 51 & 49 & 40 \\
\hline 4592913 & 42 & 35 & 66 & 47 & 56 & 43 & 36 & 45 & 54 \\
\hline 4200764 & 34 & 41 & 31 & 38 & 43 & 24 & 41 & 50 & 47 \\
\hline 4059395 & 39 & 48 & 27 & 52 & 43 & 45 & 41 & 42 & 49 \\
\hline 3032434 & 47 & 32 & 49 & 36 & 39 & 41 & 34 & 40 & 38 \\
\hline 3971031 & 62 & 58 & 40 & 39 & 51 & 33 & 54 & 55 & 44 \\
\hline 3776549 & 21 & 15 & 21 & 16 & 27 & 16 & 18 & 15 & 16 \\
\hline 3223990 & 50 & 44 & 37 & 42 & 37 & 38 & 44 & 38 & 42 \\
\hline 3790452 & 84 & 63 & 96 & 55 & 74 & 78 & 49 & 83 & 78 \\
\hline 4200748 & 28 & 38 & 50 & 42 & 46 & 42 & 54 & 34 & 41 \\
\hline 3027643 & 29 & 36 & 38 & 45 & 31 & 28 & 34 & 46 & 30 \\
\hline 3975940 & 47 & 43 & 70 & 27 & 45 & 45 & 42 & 56 & 36 \\
\hline 3009793 & 47 & 66 & 74 & 38 & 42 & 44 & 39 & 27 & 48 \\
\hline
\end{tabular}


Contagens de timócitos Foxp3 ${ }^{+}$, por campo, na medula tímica de 46 timos humanos.

(conclusão)

\begin{tabular}{|r|r|r|r|r|r|r|r|r|r|}
\hline \multirow{2}{*}{ Registro } & \multicolumn{10}{|c|}{ Células Foxp3 $^{+}$por campo } \\
\cline { 2 - 11 } & \multicolumn{1}{|c|}{$\mathbf{1}$} & $\mathbf{2}$ & $\mathbf{3}$ & $\mathbf{4}$ & $\mathbf{5}$ & $\mathbf{6}$ & $\mathbf{7}$ & $\mathbf{8}$ & \multicolumn{1}{c|}{$\mathbf{9}$} \\
\hline 3393534 & 12 & 18 & 12 & 21 & 22 & 12 & 18 & 29 & 34 \\
\hline 3082849 & 50 & 46 & 35 & 41 & 57 & 37 & 51 & 48 & 45 \\
\hline 3213056 & 41 & 47 & 45 & 33 & 59 & 47 & 43 & 51 & 38 \\
\hline 2821826 & 39 & 31 & 26 & 42 & 22 & 30 & 25 & 40 & 30 \\
\hline 3177858 & 32 & 39 & 41 & 46 & 52 & 35 & 40 & 53 & 60 \\
\hline 2851008 & 37 & 29 & 40 & 42 & 51 & 38 & 38 & 28 & 36 \\
\hline 3175472 & 38 & 38 & 48 & 55 & 51 & 42 & 39 & 31 & 31 \\
\hline 4510135 & 113 & 70 & 65 & 66 & 62 & 48 & 48 & 38 & 57 \\
\hline 752240 & 34 & 42 & 24 & 41 & 38 & 25 & 66 & 37 & 30 \\
\hline
\end{tabular}


ANEXO B.3 - Contagens de células epiteliais $\mathrm{AIRE}^{+}$, por campo, na medula tímica de 15 timos provenientes de crianças com síndrome de Down.

\begin{tabular}{|r|r|r|r|r|r|r|r|r|r|}
\hline \multirow{2}{*}{ Registro } & \multicolumn{8}{|c|}{ Células AIRE+ por campo } \\
\cline { 2 - 10 } & $\mathbf{1}$ & $\mathbf{2}$ & $\mathbf{3}$ & $\mathbf{4}$ & $\mathbf{5}$ & $\mathbf{6}$ & $\mathbf{7}$ & $\mathbf{8}$ & \multicolumn{1}{|c|}{$\mathbf{9}$} \\
\hline 3888690 & 0 & 0 & 3 & 3 & 1 & 2 & 3 & 0 & 4 \\
\hline 4191404 & 9 & 10 & 2 & 7 & 5 & 4 & 4 & 4 & 9 \\
\hline 4707745 & 0 & 1 & 0 & 0 & 1 & 0 & 0 & 0 & 1 \\
\hline 3660729 & 1 & 1 & 0 & 1 & 0 & 1 & 1 & 1 & 2 \\
\hline 3657361 & 4 & 7 & 1 & 1 & 3 & 1 & 3 & 1 & 2 \\
\hline 3161420 & 2 & 3 & 1 & 2 & 1 & 1 & 3 & 1 & 0 \\
\hline 4078608 & 11 & 5 & 10 & 3 & 4 & 7 & 2 & 7 & 4 \\
\hline 3886379 & 1 & 3 & 1 & 5 & 6 & 5 & 2 & 7 & 8 \\
\hline 4564448 & 8 & 6 & 2 & 4 & 2 & 5 & 7 & 6 & 7 \\
\hline 4423666 & 5 & 9 & 3 & 10 & 6 & 14 & 20 & 12 & 6 \\
\hline 3710920 & 15 & 7 & 15 & 12 & 13 & 7 & 11 & 6 & 6 \\
\hline 4018427 & 14 & 16 & 10 & 6 & 16 & 5 & 18 & 10 & 8 \\
\hline 3324370 & 6 & 8 & 4 & 3 & 1 & 0 & 0 & 4 & 8 \\
\hline 3314480 & 13 & 11 & 9 & 9 & 3 & 5 & 12 & 3 & 1 \\
\hline 3461351 & 1 & 6 & 1 & 1 & 2 & 2 & 3 & 4 & 2 \\
\hline
\end{tabular}


ANEXO B.4 - Contagens de timócitos Foxp3 ${ }^{+}$, por campo, na medula tímica de 15 timos provenientes de crianças com síndrome de Down.

\begin{tabular}{|c|c|c|c|c|c|c|c|c|c|}
\hline \multirow{2}{*}{ Registro } & \multicolumn{9}{|c|}{ Células Foxp3 ${ }^{+}$por campo } \\
\hline & 1 & 2 & 3 & 4 & 5 & 6 & 7 & 8 & 9 \\
\hline 3888690 & 50 & 25 & 38 & 38 & 23 & 28 & 24 & 19 & 20 \\
\hline 4191404 & 58 & 72 & 50 & 66 & 89 & 50 & 98 & 55 & 74 \\
\hline 4707745 & 15 & 17 & 21 & 18 & 25 & 15 & 31 & 22 & 16 \\
\hline 3660729 & 21 & 22 & 31 & 19 & 37 & 17 & 29 & 33 & 35 \\
\hline 3657361 & 39 & 42 & 24 & 38 & 30 & 32 & 37 & 37 & 54 \\
\hline 3161420 & 17 & 20 & 22 & 35 & 22 & 32 & 27 & 31 & 23 \\
\hline 4078608 & 138 & 79 & 75 & 53 & 82 & 65 & 95 & 68 & 71 \\
\hline 3886379 & 67 & 89 & 66 & 71 & 53 & 63 & 64 & 72 & 88 \\
\hline 4564448 & 97 & 140 & 100 & 94 & 81 & 68 & 73 & 68 & 81 \\
\hline 4423666 & 107 & 69 & 66 & 49 & 52 & 80 & 78 & 59 & 89 \\
\hline 3710920 & 91 & 118 & 90 & 110 & 93 & 101 & 150 & 110 & 98 \\
\hline 4018427 & 54 & 56 & 78 & 84 & 92 & 64 & 59 & 63 & 46 \\
\hline 3324370 & 19 & 17 & 12 & 11 & 17 & 15 & 12 & 11 & 10 \\
\hline 3314480 & 43 & 32 & 70 & 36 & 70 & 67 & 30 & 49 & 60 \\
\hline 3461351 & 6 & 16 & 12 & 11 & 17 & 10 & 16 & 15 & 12 \\
\hline
\end{tabular}


ANEXO C.1 - Produção bibliográfica: Publicação

Lima FA, Carneiro-Sampaio M. O papel do timo no desenvolvimento do sistema imune. Pediatria (São Paulo). 2007;29:33-42. 